\title{
The Principles of Political Economy (Keizai Genron, 1952/1964) in Light of Marx's Critique of Political Economy
}

The Critique of Political Economy, for Marx, does ... not consist in grasping the capital relation as a fact, but as a problem.

CLAUDIO NAPOLEONI (1974) ${ }^{1}$

The Principles of Political Economy (Keizai Genron) are without doubt Uno's most widely read work and has often been considered his main publication. It has been translated by Thomas (Tomohiko) Sekine and published in English translation in 1980. The original Japanese edition was first published as a twovolume work in 1950 and 1952 with the academic publisher Iwanami Shoten. In 1964, it was republished in an abridged version that has also been the basic text for the Sekine translation in 1964, also with Iwanami. The following argument relies on the 1964 version, the editorial changes to which Uno supervised himself.

Uno's intention in the Principles was to present his 'pure theory of capitalism' in the most concise way. The work consists of three major parts - The Doctrine of Circulation (ryütsūron), The Doctrine of Production (seisanron), and The Doctrine of Distribution (bunpairon) - and discusses the respective economic categories prevalent in each of them. Remarkably, the footnotes accompanying the main text are not only equally important as the main text, focussing on an explanatory content, but they also primarily contain Uno's discussions of Marx's own theorems, often supplemented by practical examples.

As is obvious, the structure of the themes and chapters generally leans on the three volumes of Marx's Capital - with important distinctions that also inform Uno's basic deviation from and sometimes even rejection of some of Marx's central methodological claims. To be sure, the central difference

1 Napoleoni 1974, p. 59. Our translation. 
between Marx's Capital as a Critique of Political Economy and Uno's Principles is the mode of presentation in the former: a critique of the central assumptions of classical and vulgar political economy and their 'fetishistic' and apologetic perception of capitalist society and its categories. This critique is completely abandoned in Uno's text. The Principles solely focuses on the presentation of 'the laws peculiar to capitalism', presupposing only 'the abstract context of a purely capitalist society made up of the three major classes of capitalists, workers, and landowners' ${ }^{2}$ Yet, in another contrast to Marx, Uno claims that

[by] deliberately restricting its scope to the commodity-economy ... political economy reveals the general norms of economic life common to all societies, including pre-capitalist societies ... as well as a socialist society in which the commodity-economic relation will have been superseded. Political economy ... reveals the economic base of all societies whether ancient, medieval, or modern as the substructure ... by exhibiting the selfcontainedness of the capitalist economic system ... What political economy exposes by means of the laws of a commodity-economy are, in fact, nothing other than the behavioural norms of economic life (keizaiseikatsu ni okeru kōdō no gensoku) shared by, and forming the 'substance' so to speak, of all human societies, but appearing with transparent clarity only in a capitalist society, i.e. a society totally governed by the commodityeconomic forms. ${ }^{3}$

This understanding of capitalist society as a 'sub-form' of 'general economic life' is counter-factual to Marx's understanding of the capitalist mode of production as a historically specific form of production in which the confrontation of capital and labour is the basic constellation. The assignment of (a critique of) political economy therefore consists in precisely clarifying its specificities, showing how and in what way capital is radically different from previous historical societies - one of the defining differences being the shift to the social production of value instead of use value. Accordingly, Uno's understanding of political economy to 'reveal the general norms of economic life common to all societies' ahistorically and counterfactually ascribes a universal pattern to the historical specificity of the capitalist relations of production, much akin to the classical political economists Marx has precisely criticised for this view. Uno's definition, that the 'economic base of all societies, whether ancient, medieval

2 Uno 1980, p. Xxii.

3 Uno 198o, p. xx. See Uno 1964, pp. 3-4. 
or modern' is 'revealed' by political economy, also implies that the modes of general social reproduction are common to all societies. It is precisely this view that Marx contests. Capitalism's mode of social reproduction follows laws quite distinct from that of pre-capitalist societies and therefore cannot be subsumed under an 'economic base' allegedly 'common to all societies'. We will see in the following that this central view of Uno's is owed to a strong emphasis on a functioning reproduction in the economy in general, while disregarding the specific conditions of capitalist reproduction, especially the circulation of values based on unpaid labour. Uno's model, as we will see, is contrary to Marx's in that it is concerned with successful and unhindered reproduction, and not with problems associated with the hampering of reproduction, i.e. crisis. Following from this, our discussion of Uno's theory of reproduction will question the equilibrium view that systematically excludes the possibility of reproductive crisis. In this context, we will show that Uno does not hold any viable theory of the capitalist valorisation crisis, but a theory of business cycles, in which equilibrium is always restored. For Uno therefore, the capitalist economy as object of research is much rather a fact than a problem.

As for a more detailed presentation of Uno's deviations from Marx with regard to the conceptual and structural approach to theorising the capitalist economy, these will be critically discussed in the following chapter.

\subsection{The Reconstruction of Capital}

In the previous chapter, we could see that for Uno, the specificity of commodity economy consists not in its production mode, but in its forms of circulation. ${ }^{4}$ The preference for form over substance - which we have critically revealed as a preference for formalism over an analysis of the social conditions of production that necessitates the very forms in which they appear in the first place - motivates Uno's intervention. The understanding of social substance as being entirely subsumed by the circulation forms of capital forms the guiding principle for Uno's reconstruction of the methodological structure of Capital undertaken in his main work that shall be discussed in this chapter. Uno's insistence that 'the production process is subsumed under cap-

4 'It deserves a great deal of attention that the labour-and-production process that is common to all societies can be subjected to a theoretical analysis only at this juncture of the Doctrine of Production in the pure theory of capitalism'. Uno 1980, p. 22. See also our discussion of the transhistorical character of abstract labour in Chapter 3.1. of this volume. 
ital which ... provides the form-determination of value 5 sets forth his motivation to rewrite the structure of Capital in the Principles of Political Economy. The following table ${ }^{6}$ presents Uno's structuring in direct comparison with the chapters and sections in Capital that roughly correspond to the Principles of the 1964 edition: $^{7}$

Principles of Political Economy

PART I: The Doctrine of Circulation

Introduction

Principles of Political Economy

1. Commodities

2. Money

3. Capital

PART II: The Doctrine of Production

Introduction

1. The Production-Process of Capital

The Labour-and-Production-Process

The Process of Value Formation and Augmentation

The Development of the Capitalist

Mode of Production
Capital

Volume I: The Production Process of Capital

Part One: Commodities and Money

Capital

Ch. 1: The Commodity

Ch. 2: The Process of Exchange

Ch. 3: Money, or the Circulation Commodities

Ch. 4: The General Formula for Capital

Part Three: The Production of Absolute

Surplus-Value

Ch. 7: The Labour Process and the Valorisation Process:

The Labour Process

The Valorisation Process

Part Four: The Production of Relative

Surplus-Value

5 Uno 1973 [1962], p. 158.

6 See also Hoff 2008 and Hyeon-Soo 1995. Hoff however only compares the structure of Part III with the one of Volume III, and Hyeon-Soo does not directly juxtapose Uno's structure to that of Marx. Hoff 2008, p. 108; Hyeon-Soo 1995, pp. 64-5.

7 The main text of the original 1952 version is twice the length of the 1964 version. Uno himself supervised and made the editorial changes to the abridged version. 
2. The Circulation-Process of Capital

3. The Reproduction-Process of Capital

Simple Reproduction: The Reproduction of Capital and Labour-

Power

Expanded Reproduction: The Actual Process of Capitalist Accumulation The Reproduction-Process of the Aggregate Social Capital: The Absolute Foundation of the Law of Value

PART III: The Doctrine of Distribution

Introduction

1. Profit

The Formation of the General Profit Rate: Transformation of Values into Production Prices

Market Prices and Market Values (or Market Production-Prices): Demandand-Supply-Relation and the Formation of Surplus Profit

The Falling Tendency of the General Rate of Profit: The Advancement of Productive Powers and Business Cycles

2. Rent
Volume Ir: The Circulation Process of Capital, Part One: The Metamorphoses of Capital and their Circuit - Part Two: The Turnover of Capital

Volume I: Part Seven: The Process of Accumulation of Capital

Ch. 23: Simple Reproduction

Ch. 25: The General Law of Capitalist Accumulation

Volume II: Part Three, Ch. 20-21: Accumulation and Reproduction on an Expanded Scale, Section 1: Accumulation in Department I, and Section 2: Accumulation in Department II

Volume III: The Process of Capitalist Production as a Whole

\section{Part Two: The Transformation of Profit into Average Profit}

Ch. 9: Formation of a General Rate of Profit (Average Prate of Profit), and Transformation of Commodity Values into Prices of Production

Ch. 10: The Equalisation of the General Rate of Profit through Competition. Market Prices and Market Values. Surplus Profit.

Part Three: The Law of the Tendential Fall in the Rate of Profit

\section{Part Six (Ch. 37-47): The Transformation} of Surplus Profit into Ground Rent 
3. Interest

Loan-Capital and Bank Capital

Commercial Capital and its Profit

Capital as an Automatically InterestBearing Force
Part Five (Ch. 29-36): The Division of Profit into Interest and Profit of Enterprise

Ch. 21-23, 25-27, 29-32 (Banking Capital, etc.)

Part Four (Ch. 16-20): The Transformation of Commodity Capital and Money Capital into Commercial Capital and MoneyDealing Capital (Merchant's Capital)

Ch. 24: Interest-Bearing Capital as the Superficial Form of the Capital Relation

As we can see from this direct comparison, Uno's Principles, being a work of no more than 126 pages in the Sekine translation, ${ }^{8}$ can in no way correspond to all the chapters and issues of the three volumes of Marx's Capital. Neither can it hope to address all of its issues, let alone analyse them. Especially the bulk of what Marx has conceptualised and developed as the direct critique of the main contentions of classical economic thinkers goes unmentioned in Uno's work. But the decision to undertake Capital's reconstruction, and the omissions undertaken by Uno to establish his own version of the 'pure theory of capitalism', are, as I will argue, themselves symptomatic for his formalistic reading of the critique of political economy. Regarding the reconstruction of the rough structure, what we can notice at first sight is the following:

a) Uno starts his Principles with 'The Doctrine of Circulation', in the context of which he analyses the categories of the commodity, money, and capital, in contrast to Marx who develops the same categories in the context of The Production Process of Capital, beginning with the commodity and money.

b) In Part III, corresponding to Volume III of Capital, Uno undertakes a complete reversal of parts four, five and six, which now appear in inverted sequence: instead of commercial capital, interest, and rent, Uno first discusses rent, then interest, and, lastly, commercial capital. The discussion of Part Seven of Volume III, 'The Revenues and Their Sources', is quickly treated in the last section of 'Interest', 'Capital as an Automatically Interest-Bearing Force', where Uno also references Chapter 24 of Volume III, 'Interest-Bearing Capital as the Superficial Form of the Capital Relation'. By also subsuming commercial capital under 'interest', Uno stresses the pre-eminent function of interest and credit for

8 The original of 1964, published with Iwanami Zensho, is 220 pages long. 
the reproduction of capital. Like Marx, however, Uno insists that interest is 'the form in which the fetishistic character of capitalist production reaches perfection. 9

c) Having discussed the circulation process of capital in Chapter 2, Uno then returns to Capital Volume I in Chapter 3 of the Principles, giving it the title 'The Reproduction-Process of Capital'. Here, Uno intends to show that the general reproduction process must be situated within the context of Volume II, not in the context of Volume I where it is discussed in Part Seven, 'The Process of Accumulation of Capital'. Uno relocates this part within the context of Volume II. Hence, the accumulation process of capital is described within the context of the reproduction schemes of Volume II. One of the reasons for this, as we will see, is to de-emphasise the significance of accumulation. The closing section of 'The Reproduction-Process', subtitled 'The Absolute Foundation of the Law of Value' therefore roughly corresponds to the 'Accumulation and Reproduction on an Expanded Scale' of Volume II. We will discuss Uno's motivation to relocate 'The Process of Accumulation' within the context of Volume II and especially the reproduction schemes at the end of the present chapter (4.1). With it, we will be able to better understand why and how 'The Absolute Foundation of the Law of Value' is central to Uno's theory of general social reproduction, based on his understanding of the 'law of value' to be discussed in Chapter 4.2.

It is crucial in this context to point out that in the Principles, the different levels of conceptual analysis undertaken with the structure of the three volumes of Capital, are anathematic. In contrast, in Capital, the different levels of analysis define the object of research: the manuscripts to Volumes I and II, and even the first seven chapters of Volume III, present the essential conceptual analysis that informs the sine qua non of the capitalist mode of production as the relation between capital and the exploitation of alien, unpaid labour. Of the two big innovations Marx prided himself on, one was the discovery of profit in its 'pure form', namely surplus value - unlike Ricardo who only knew surplus value in its already falsified or fetishised form of appearance, as profit and rent. ${ }^{10}$ Here, Marx's critique directly engages theories of equivalent

\footnotetext{
$9 \quad$ Uno 1980, p. 74 .

10 'The best points in my book are: 1. (this is fundamental to all understanding of the FACTS) the two-fold character of labour according to whether it is expressed in use-value or exchange-value, which is brought out in the very First Chapter; 2. the treatment of surplusvalue regardless of its particular forms as profit, interest, ground rent, etc. This will be made clear in the second volume especially. The treatment of the particular forms in classical political economy, where they are for ever being jumbled up together with the general form, is an olla potrida!' Marx to Engels, 24 August 1867. Marx and Engels 1987, p. 407. See
} 
exchange and surplus value. From here, he conceptually develops the process of valorisation, accumulation, reproduction, and crisis as form determinations defining the capital relation as a historically specific economic social relation. Volume III, starting with the 'Transformation of Profit in Average Profit' is restricted to the level of appearance, based on the form determinations analysed in the two previous volumes. By having previously analysed the essential conceptual nexus of the capitalist mode of production in vols. I and II, Marx could now move on to its forms of appearance in the manuscripts comprising Volume III. Value here appears as price of production, surplus value as profit, and capitalist accumulation as the generation of a general profit rate. This is important for Marx's fetish-critical method: the fetish-characteristic forms of value - as different forms of price (production price, cost price, sales price, market price), industrial and commercial profit, interest and rent - receive their 'final ossification' in Volume III, for which the analysis of the first book holds the key, and which can now be revealed in their inverted self-presentation. This is demonstrated for example in Marx's discussion of cost price and commodity value in the first chapter of Volume III: the difference in price (and the origin of profit) results not from the commodity value and sales price, but from the difference between cost price and the commodity value - in short, the difference between the cost for the capitalist and the profit earned by the same capitalist in applying unpaid labour in the production process. The concept of cost price that treats variable capital as constant capital 'under the heading of circulating capital' obscures this, however. ${ }^{11}$ This also shows the importance of Volume II and its conceptual clarifications of fixed and circulating (fluid) capital as a subspecies of constant capital, conceptually distinct from variable capital. There is a second reason for this specific structure of the three volumes: in the context of Volume III, commodities are 'in fact' products of capital. This is not the case in the presentation of Volume I where the general systematic conditions of the commodity as a product of capital are analysed. These conditions lie within the systematic foundation of the capitalist mode of production, the production and the circulation process of capital.

also Marx's letter to Engels from 8 January 1868 as quoted in Chapter 1.2. of this volume. Marx and Engels 1987, p. 551 .

11 'As far as value formation is concerned ... the variable portion of capital, that laid out on labour-power, is expressly identified here with constant capital (the portion of capital consisting of production materials), under the heading of circulating capital, and thus the valorization process of capital is completely mystified'. Marx 1981, p. 124. 'Profit, as we are originally faced with it, is thus the same thing as surplus-value, save in a mystified form, though one that necessarily arises from the capitalist mode of production'. Marx 1981, p. 127 . 
In Volume III, the pivotal concept of competition that as yet has been disregarded in the previous analysis now becomes a defining concept. But because ' $[i]$ n competition ... everything appears upside down', 12 it affects also our epistemological access to the phenomenon of profit. Profit must therefore be analysed separately, namely as the appropriation of surplus value, in accordance with Marx's labour theory of value. However important the distinction, Uno's principles of reconstruction do not reflect the 'leap' from the essential and basic to the superficial and 'fetishistic' determinations of value. Here, too, we can detect Uno's negligence to see Capital first and foremost as a critical examination of the fetish character of conventional economic categories.

Concerning the omissions of the reconstruction, as we have indicated before in the discussion of Uno's treatment of merchant capital, Uno (a) altogether omits Chapter 5, 'Contradictions of the General Formula' of Capital (M-C-M'), and, in direct relation, Chapter 6, 'The Sale and Purchase of Labour-Power'. He thereby excludes the central theoretical intervention Marx undertakes in his critique of 'circulation theories' of surplus value, and the fetishistic illusion appearing from it, so that (b) Uno does not develop a concept of surplus value from the critique of circulation theories of surplus value, and hence, a theory of exploitation that stands at the heart of Marx's critique of the classics and the 'vulgar' economists. Instead, Uno's conception of surplus value is relocated within the context of 'value augmentation', i.e., 'The Valorisation Process' of capital, without a preceding analysis of what Marx calls 'the conditions of the problem' - namely how the exchange of equivalents can generate a part of the total produce as surplus value, appropriated as profit. Uno is oblivious to this central self-posed research framework that marks Marx's central difference to conventional economic theory. Even more, Uno accuses Marx of not having strictly concluded the form determination of capital from the commodity and money - disregarding the critical analysis Marx's analysis is embedded in: 'Capital has not sufficiently developed "The Transformation of Money into Capital" clearly as the form determination proceeding from the commodity and money. Besides, as in the case of the commodity and money, with respect to their emergence in history, it also shows the historical development theoretically'13

(c) Uno omits the first two parts of Volume III - 'The Transformation of Surplus-Value into Profit, and of the Rate of Surplus-Value into the Rate of Profit' and 'The Transformation of Profit into Average Profit'. Especially the exclusion of Part One (Chapters 1 to 7 ) renders Uno's understanding of the

12 Marx 1981, p. 311. Emphasis in the original.

13 Uno 1962 [1974], p. 297, footnote. 
so-called transformation problem incomplete. In this part, Marx shows how surplus labour related to variable capital, i.e. the part of capital used to keep labour power in the valorisation process, is distorted: with the origin of surplus value appearing to lie in both variable and constant capital, value appears to be the outcome of both labour and the means of production in equal ratio. Uno however does not recur to this problem in the Principles. Quite to the contrary: for Uno, the question of the transformation of values to prices of production becomes a question of general equilibrium, hence equilibrium prices. Supply and demand regulate the production price and socially necessary labour time in the last instance, so that the validity of 'the law of value' can be shown only in the phenomenon of equilibrium prices that serve to satisfy general demand. ${ }^{14}$ In this sense, the distribution of surplus value as profit serves the aim of satisfying general social demand. This happens, as Uno insists, in contrast to the rate of surplus value $(\mathrm{s} / \mathrm{v})$, which indicates 'the social relation of workers visà-vis capitalists.' ${ }^{15}$ The rate of profit $(\mathrm{s} / \mathrm{c}+\mathrm{v})$, in contrast, indicates the relation among capitalists alone:

The latter relation $[\mathrm{s} / \mathrm{c}+\mathrm{v}]$ places capitalists, so to speak, outside of the production process allowing them to observe the efficiency of its value augmentation per given period of time. Thus the rate of profit offers a standard, according to which capital selects various spheres of investment so as to produce and supply the diversity of the use-values that are socially demanded, though capital itself is not directly interested in these usevalues. This is the manner in which capital satisfies the social demand, making a commodity-economic detour, so to speak, and developing in concrete terms a peculiarly commodity-economic principle of capitalist distribution. ${ }^{16}$

We will return to Uno's idiosyncratic view of an alleged compatibility of capitalist accumulation with 'social equilibrium' in the next chapter (Chapter 4.2.).

In sum however, rather than for his omissions, in the Principles and other writings, Uno gives reasons for his reconstruction of Capital. In the following,

\footnotetext{
14 Although it must be noted that Uno's view does not quite correspond to Sekine's interpretation of him: '... the third doctrine of distribution shows how the capitalist mode of production develops and regulates its own market so as to produce all use-values that are socially needed in a manner that is most satisfactory to the self-adopted aim of capital'. Thomas Sekine, 'An Essay of Uno's Dialectic of Capital', in Uno 198o, p. 148.

15 Uno 1980, p. 73.

16 Uno 198o, p. 73. Original emphasis. See Uno 1964, pp. 137-8.
} 
let us consider how Uno justifies the relocation to place I) the circulation forms before and in separation from the process of production and II) rent before interest, and accordingly, before bank and commercial capital. Here, Section 4 of his 1962 writing The Methodology of Political Economy (Keizaigaku hōhōron) is telling. In this section, titled 'About the Structure of the Sections (in Capital)', Uno for the first time discusses his critique of Marx's general architecture of Capital which formed the basis for Uno's reconstruction in the Principles.

\subsubsection{Circulation before Production}

That Marx had allegedly introduced the labour theory of value 'prematurely' into his discussion of the commodity form had already been a prevalent criticism in Value Theory, as we have seen in the previous chapter. In 'About the Structure', Uno reiterates the argument, while stressing the place of the 'form determinations' of the commodity, money, and capital within the complete structure. For Uno, especially Volume II is of great importance, less in its 'mediating' function, but rather because the form determinations show their actual impact on the logic of the reproduction of capital. Here, we are also presented with Uno's argument for placing reproduction theory not within the 'Production Process', but solely within the context of Volume II and the reproduction schemas:

In Section 3 of vol. $2,{ }^{17}$ Marx says that '[ $t$ ]he total process presents itself as the unity of the process of production and the process of circulation'. But the relation between the theory of reproduction in volume 1, especially with its theory of population, to the so-called reproduction schemes in vol. 2, is unclear. As against the consideration of the form determination of the commodity, money, and capital within the context of 'The Production Process of Capital' in volume 1, 'The Circulation Process of Capital' is considered after the reproduction process of vol. 1, in the separate volume II. $^{18}$

Because for Uno, the form determinations of the beginning 'encroach' upon the production process, the relation between reproduction and especially the law of population must be elucidated within the theory of circulation. But why are the forms necessarily 'external to the production process' ${ }^{19}$ for Uno? There is

17 The passage quoted by Uno is in Chapter 4 of Volume 2, not in Section 3.

18 Uno 1962 [1974], pp. 287-8.

19 Uno 1962 [1974], p. 289. 
both a historical and a logical reason for this. As we have seen in Chapter 2, Uno relies heavily on a remark by Marx in the analysis of The Exchange Process of Volume II, namely that 'The exchange of commodities begins where communities have their boundaries, at their points of contact with other communities, or with members of the latter'.20 This remark is used ad nauseam by Uno to stress the historical emergence of production on the basis of a particular type of exchange, here, communal exchange. ${ }^{21}$ At the same time, as seen previously, the labour and production process is conceived as a transhistorical one, i.e. a process that is shared between such disparate economic forms as Robinson Crusoe's island and highly developed industrial capitalism. Hence, for Uno

[the] unfolding of the circulation forms of the commodity, money, and capital, when clarified to grasp the production process at the basis of the capital form, must explain the labour-and-production process as the social substance that is common to all social formations ... The labour process common to all societies is subsumed under its specific social forms, ${ }^{22}$

that is, the commodity form, money, and capital.

This is also why

the form determinations of the commodity, money, and capital must be developed in pure form. Furthermore, it makes the determinations of the abstract labour-and-production process its basis, and hence the substance of value can be clearly shown. There may be people who think this view is against the materialist view of history in which the production process is thought to be the foundation. However, this only mechanistically applies to the materialist view of history. Commodity economy itself hasn't evolved from the inner [structure] of the production process, it did not develop from the production process. The production process has both a beginning and an ending within commodity economy. This is why Marx began Capital with the commodity and money, not with the labour-and-production process. Rather, the development from the

\footnotetext{
$20 \quad$ Marx 1976, p. 182.

21 As we have seen in the previous chapter, Uno rejects the hypothesis of 'primitive accumulation' in the case of Japan.

22 Uno 1962 [1974], p. 29 o.
} 
commodity makes the direct explanation of the substance of value in labour (sic) impossible. ${ }^{23}$

In the foregoing - see especially the introduction to our Chapter 2 - we have already discussed why Marx begins with the commodity: not because it is separate from the process of production, but because generalised commodity production is one of the conditions on which the emergence of the commodity form can take place at all. The separation of the direct producers from the means of production, the origin of generalised commodity production with the commodification of labour power, is a relation 'inherent in production itself'. ${ }^{24}$ In the introduction to the Principles, Uno is even more outspoken: the commodity and the money form derive their specificity not from the specific form of production, but to the contrary, from the form determinations of circulation. The latter therefore determines which transhistorical laws of production (keizai gensoku) are to be assumed in the case of specific economies. The 'pure theory' of capitalism therefore primarily thematises the forms peculiar to capitalism, in which these forms present particular general forms of circulation, i.e. the commodity, money, and capital:

... the commodity-economy, the forms of which are required to disclose the general economic norms, does not evolve from within the production process of a society, i.e., from the root of its economic life (keizai seikatsu no kiso). It arises, as already pointed out, from the exchange relation between one production-process and another. The forms of human relation peculiar to commodity exchanges then influence the productionprocesses by reaction, sink slowly into them (shintō shi), and finally take possession of them; the commodity economy thus secures the substantive base of its operation in a production-process by gradually encroaching upon it from the outside. It is for this reason that the pure theory of capitalism cannot begin with a doctrine of production, despite the widely held view to the contrary that political economy should first examine the process of production which forms the real base of any economic process. Marx's Capital, Volume One, though entitled 'The Production-Process of Capital', begins in fact with the discussion of such circulation-forms; only after the development of the form of capital does it turn to the analysis of the labour-process which is common to all societies, finally opening

23 Uno 1962 [1974], pp. 29o-1.

24 Marx 1978, p. 196. 
the real treatment of the production process of capital ... The pure theory of capitalism must, in any case, begin with the doctrine of circulation in which the forms of circulation alone are to be examined. The doctrine of production can then treat the production-process that conforms to these circulation forms. ${ }^{25}$

First, as discussed in Chapter 3, this enterprise is not only diametrically opposed to Marx's understanding of social form which pertains to the specific form of labour peculiar to capitalism, namely value-producing abstract labour where 'in fact, the whole secret of the critical conception [is].26 Uno's view is opposed to Marx's method in which precisely the so-called 'forms of circulation' are embedded within the volume of the Process of Production to dismantle the fetishistic illusion that the commodity, money and capital are merely 'forms of circulation'. Second, it is not exactly clear how, if the production process is common to all societies, the presentation of the production process from Chapter 7 of Capital Volume I onward should be able to address the 'peculiarity' of the capitalist production process without a preceding mediation through the categories that supposedly render the production process specific. It rather seems that the claim of a 'premature discussion of the labour theory of value' is a petitio principii. The petitio, in fact, consists in maintaining that we must postpone the discussion of the labour and production process until the alleged form of circulation has been 'explained': because at what point, and with what methodological justification, could the defining concepts of the capitalist mode of production suddenly become a part of the analysis? Each category is set into the method of the mediation, towards more concrete and more precisely defined terms, which serve to grasp the capital relation as a whole. The commodity presented at the beginning of Capital is the capitalist commodity, but what it means to be 'capitalist' can only be fully elucidated with further mediation. This does not mean however that capitalist production can be abstracted from the concept of the commodity: without capitalist production, there would not be a commodity, much less a commodity form. According to Uno's understanding of the correct method, however, production would have to be suddenly inserted, externally, and without mediation, after the circulation forms. But to grasp the forms of circulation requires a grasp of the complete process of production, and the specific ways the real subsumption of labour under capital or the class relation is enacted. Uno misrecognises

25 Uno 1980, p. xxiv.

$26 \quad$ Marx and Engels 1987, p. 514. 
that, for Marx, the forms of circulation - especially money as the predominant value form - is necessitated by a specific form of production, which makes general commodity exchange its only mode of social metabolism. By prioritising circulation over production, Uno fails to address the peculiarity of this production mode. With it, he misrecognises the role of abstract human labour, made palpable by money, as the general social mediator. We seem to have come to the point already addressed in Chapter 1 with regard to Chris Arthur who, unlike Uno, does not suppose a transhistorical understanding of the production process, but, like Uno, believes that production in Capital is discussed 'too early'. Here, I argue, is where the source of the confusion lies: precisely by thematising production right from the start of the exposition, Marx cannot only circumvent the problem of justifying an unmediated thematisation of 'production' at some random point, but by explicitly thematising production from the beginning, Marx delivers the key to unravelling precisely the illusion that production is peripheral to the discussion of the value forms.

\subsubsection{Rent before Interest, Banking before Commercial Profit}

The next question concerns how Uno justifies the re-shifting of the chapters in Capital Volume III, corresponding to his 'Doctrine of Distribution' in the Principles. The Doctrine of Distribution, forming Part Three of the Principles, addresses the distribution of surplus value among the different branches of industrial capital, landed property, and bank capital (interest and credit). At first sight, we can notice that Uno relocates the concept of rent from the relative end of Marx's exposition in Capital Volume III (Chapter 37 to 47 of 52 chapters in total) to the relative beginning, right after the discussion of profit. Uno defines rent as 'a concession of capital to the proprietors of limited and monopolisable natural powers, generically represented by land, which are needed as means of production in the production-process of capital, but which also set an external restriction in the activity of capital. ${ }^{27}$ Interest, 'on the other hand, is the transfer of incremental surplus value produced in consequence of the utilisation of idle money-capital ... as investible funds by other capitals. ${ }^{28}$ As to their basic conceptual difference, which also justifies the order in which they appear in the structure of the Principles, Uno claims that 'rent is earned from a direct participation in the production-process of capital, unlike interest which derives from a supplementary and additional contribution to the motion of capital. Hence, after profit, the Doctrine of Distribution must first treat rent

$27 \quad$ Uno 198o, p. 73.

$28 \quad$ Uno 198 o, p. 73 . 
and next discuss interest'. ${ }^{29}$ The re-shifting of bank capital before commercial capital follows the same logic: while bank capital can still be said to emerge in indirect form from the production process of capital, commercial profit 'is no longer directly tied to surplus value obtained in the production-process of capital; it seemingly springs from the entrepreneurial activity of the capitalists' ${ }^{30}$ For Uno, the saving of circulation costs by the mediation of commercial capital forms the condition of possibility for the emergence of idle money funds that can serve as loan capital, and therefore the condition of possibility of interest-bearing capital. ${ }^{31}$ Interest therefore must be referred to a place in the structure further removed from the actual process of the generation of an average profit rate. Accordingly, we have two results in the Principles in contrast to the structure of Capital Volume III: with regard to the rough structure (profit-interest-rent), according to Uno, interest is less directly involved in the production process of capital than rent and must therefore be treated at the end of the analysis, so that 'capital-rent-interest' becomes the correct sequence. In the same vein, concerning the more filigree structure within the analysis of Interest (loan and bank capital - commercial capital and its profit - Capital as an Automatically Interest-Bearing Force), commercial capital must be treated after bank capital, as it conceptually presupposes the mediating activity of credit or loan capital in order to serve as the mediator of the saving of circulation costs in the production process. Rather than counterpose the different semantics of the concepts of rent, interest (bank and commercial profit) and the accumulation process of capital discussed within the framework of reproduction in Uno's interpretation as against that of Marx, let us take a closer look at the different systematic locus of these concepts within their respective works. As a matter of fact, the reflection on the systematic position of the respective categories will also provide valuable insights as to their semantics in Uno and Marx. But the following shall not be read as an exhaustively performed comparative conceptual analysis. Rather, limiting the comparison to the respective order in which the concepts appear will not only help us understand Uno's structural deviation from Marx's, but also the relocation as a shift of emphasis

\footnotetext{
29 Uno 1980, pp. 73-4. To emphasise the importance of this point, Uno remarks that 'I believe that the formation of rent can and must be logically explained prior to the emergence of interest motivated by the saving of circulation costs'. Uno 1980, p. 75 .

30 Uno 198o, p. 74: 'The financing of idle money-capital generated from the motion of industrial capital, i.e. the conversion of such money-capital into investible funds, is arranged by the special institution known as a bank, which develops into bank-capital with a share in the general profit'. Original emphasis. 
on the taxonomic order in order to stress the respective relevance of these concepts in their structural nexus for understanding capitalist totality.

In Uno's theory, the concept of rent is arguably developed in closest accordance with Marx's, despite the difference of locus in the structure of Volume III. However, two conceptual deviations exist. They do not in themselves explain the shift of rent before interest, which for Uno is exhaustively explained by rent participating directly in the production process and the formation of a general profit rate as the direct mode of distribution among the different capitals while interest does not directly participate in it. But they can help to highlight a methodological inconsistency in Uno's alternative conceptualisation, as well as Uno's and Marx's difference in emphasis as to the purpose of the theory of rent. Let us first review the changed locus of Uno's concept of rent.

\subsubsection{Rent}

First, Uno stresses that rent presupposes landed property, which in itself cannot be explained as a result of the capitalist law of appropriation. In other words, the capital relation does not create landed property as its principle. Rather, the emergence of 'modern' private ownership of land - which is not equivocal with the 'capitalist' ownership of land - is the necessary historical precondition for the generation and the development of capitalist production, but it does not create it: 'Although the conversion of surplus profit into rent characterises the capitalistic form of land-ownership, this conversion does not generate land-ownership itself'.32 In an attempt to defend Hegel's notion of private landed property against Marx's critique, ${ }^{33}$ Uno claims that

the ownership of land constitutes the foundation of all other forms of private property, including what Marx calls 'private property based on the labour of its owner'. The fact that capitalism presupposes the severance of the direct producers from land does not simply give rise to the so-called capitalist law of appropriation; that fact also brings all the forms of private ownership that a commodity-economy involves into a well-

32 Uno 1980, p. 106, footnote 8. This argument is directed primarily against both Ōuchi Tsutomu's and Hidaka Hiroshi's critique of Uno that pure theory presupposes a historical precondition while the theory of capitalist ground rent can explain the logical necessity of landed property without reference to history. The debate between Uno on the one hand and Ouchi and Hidaka on the other also included questions of the exact determination of absolute rent, the rule of the 'descending order' in differential rent I that 'presupposes freedom on the part of capital to invest on superior rent first', a view that Uno rejects. See Uno 1980, p. 106. See Ōuchi 1958 and Hidaka 1962. 
defined social institution. Since any form of labour is a human activity applied directly or indirectly to land, capitalism requires the institution of private property securely rooted in the private ownership of land in order to appropriate surplus labour at all. ${ }^{34}$

Therefore, landed property already owns 'natural powers', such as land, 'and must confront capital as an alien property, so that the capitalist should be obliged to rent from their owners such natural powers whenever he wants to use them as means of production'. ${ }^{35}$ This argument is not entirely alien to Marx's. However, in Marx's structure, the emergence of private landed property as a necessary precondition for the capital relation had already been explained on the basis level of the theory of Capital, concluding Volume I and its discussion of primitive accumulation. In introducing rent in Part 6 of Capital Volume III, Marx can refer to rent's historical conditions as they have previously been explained:

Landed property presupposes that certain persons enjoy the monopoly of disposing of particular portions of the globe as exclusive spheres of their private will to the exclusion of all others. Once this is given, it is a question of developing the economic value of this monopoly, i.e. valorizing it, on the basis of capitalist production. In the section on 'Primitive Accumulation' (Volume 1, Part 8) we saw how this mode of production presupposes on the one hand that the direct producers are freed from the position of a mere appendage of the soil (in the form of bondsmen, serfs, slaves, etc.) and on the other hand the expropriation of the mass of the people from the land. To that extent, the monopoly of landed property is a historical precondition for the capitalist mode of production and remains its permanent foundation, as with all previous modes of production based on the exploitation of the masses in one form or the other. ${ }^{36}$

34 Uno 1980, pp. 103-4, footnote 1.

35 Uno 1980, p. 97.

36 Marx 1981, pp. 753-4. In addition, Marx dedicates a chapter on the historical 'Genesis of Capitalist Ground-Rent' (Chapter 47) after its systematic analysis, in accordance with the 'Historical Material on Merchant's Capital' (Chapter 20) supplementing its logical analysis in Chapters 16-19, and the presentation of 'So-Called Primitive Accumulation', that also forms the conclusion to the previous analysis of the production process in Volume I of Capital. The reasons for this particular systematic sequence in Capital - the presentation of the historical only after the logical presentation - have been discussed in Chapter 2.1. of this volume. 
Since Uno rejects the grounding function of primitive accumulation for the emergence of the capital relation, in order to substitute it with a theory of original exchange (as shown in Chapter 2.1.), he is now at pains to argue the necessary historical precondition of privately owned landed property for the emergence of rent under capitalist conditions. At the same time, he stresses the importance of the historical precondition to conceptually develop rent. In other words, because pure theory nowhere accounts for the 'severance of the direct producers from land', it cannot account for the conceptual development of rent by its own method. However, the difficulty of integrating the concept of rent into the pure theory itself is beyond Uno's consideration. For Uno, rent simply requires an already existing landed property, but as to how this historical precondition can be explained on the basis of his pure theory of capitalism remains obscure. Additionally, not only rent, but the 'institution of private property' as such is required for capitalism in order to develop its own faculties, as Uno asserts. But this cannot be elucidated on the basis of his own theory. Instead, for Uno, the explanation offered in the Methodology and elsewhere, namely that the capitalist mode of production originated in exchange 'outside of the boundaries of communities', i.e. merchant capital, rather than in expropriation, serves as the theoretical foundation of his study of capital as 'pure theory'. ${ }^{37}$ This is a grave lacuna in Uno's pure theory, and even more so since Uno nowhere in his discussion of rent reflects on this obvious methodological flaw. Yet, Uno agrees with Marx that the compatibility of landed property with the form of capitalist production has yet to be established by capital. ${ }^{38}$ In this sense, the theory of rent must - for both Uno and Marx - explain how a specifically capitalist ground rent is made compatible with the capitalist mode of production. The question at hand is how rent enters into the formation of a general profit rate. Uno:

All this [the discussion of the function of differential rent I and II] boils down to the fundamental issue concerning the method of theorising in the context of pure capitalism: the process in which landed property develops its particularly capitalistic form ... It is therefore neces-

37 See e.g. Uno 1974 [1962], p. 213.

38 'But the form in which the capitalist mode of production finds landed property at its beginning does not correspond to its mode. The form that does correspond to it is only created by it itself, with the subjection of agriculture to capital; and in this way feudal landed property, clan property or small peasant property with the mark community is transformed into the economic form corresponding to this mode of production, however diverse the legal forms of this may be'. Marx 1981, p. 754 . 
sary to show that the first form of differential rent, which arises from the need of capital to convert its surplus profit into rent, constitutes the first step towards the capitalistic characterisations of landed property; the second form of differential rent constitutes the second step imposing, so to speak, a passive constraint upon the process of capital accumulation by the landed property, which again conforms to the commodityeconomic principle of capital ... Capital, let me repeat, does not create land-ownership as such, but requires the particular form of landownership suitable to its production process. The discussion of rent in the pure theory of capitalism accordingly exhibits the theoretical compatibility of the form of landed property with the production process of capitalist society. ${ }^{39}$

Consequently, Uno claims that ' $\mathrm{r}] \mathrm{ent}$ is formed because capital cannot by itself absorb surplus profit arising from the use of limited land without violating its own principle of equality' ${ }^{40}$ By this he refers to the contribution of rent to the formation of a general rate of profit. However, in the Principles, we also find reference to his stages theory that must explain 'deviations' from the 'rule-of-thumb', i.e. that capitalist rent presupposes private ownership of land. This deviation can e.g. be found in the case of Japan: 'In a country like Japan, however, in which capitalism evolved relatively late, it was not necessary for capitalism to "subordinate agriculture to capital" in order to achieve a high level of development ... This fact suggests that the purely theoretical study, though indispensable, cannot be immediately applied to the concrete analysis of the Japanese experience.'41 The 'theory of pure capitalism and empirical analysis must always be mediated by a stage-theoretic characterisation. ${ }^{42}$ In Chapter 2, we have seen how this mediation itself becomes external to a coherent theory of capital, encompassing all 'levels'. In his more methodological reflections, Uno fails to address what understanding of capitalism justifies the systematic coherence and therefore the unity of the three levels of pure theory, stages theory, and analysis of the empirical facts. The 'Three Level-Method' (sandankairon) therefore invites an infinite regress to the method of political

\footnotetext{
39 Uno 1980, p. 107, footnote 9.

$40 \quad$ Uno 1980, p. 100.

41 In same passage quoted above, Marx contends that the subjugation of agriculture to capital has not been smoothly conducted everywhere. Interestingly, he also chooses Asia as an example: 'In Asia, it [capitalist production] has simply been imported here and there by the Europeans'. Marx 1981, p. 753 .

42 Uno 1980, p. 104, footnote 2.
} 
economy, since the three stages cannot - by means of their own conceptual definition - account for their own unity. Furthermore, in the context of the theory of rent, the tacit presupposition of the theory of primitive accumulation, i.e. of a historical precondition not answered for in pure theory, is ominous. The presupposition of landed property in general, feudal terms, for both the formation of a specifically capitalist landed property and the entering of surplus profit into the general rate of profit, is methodologically undermined by Uno's failure to include primitive accumulation, i.e. the expropriation of land from the small peasantry, into the pure theory he draws on in order to explain its own terms in a 'self-contained' way.

Second, for Uno, the theory of rent supplements the theory of profit, while no more consequences can be drawn for the systematic position of rent within the general structure. For Marx, the emphasis on rent - discussed after interest - is different. It is more closely connected to the theory of the so-called 'three sources of revenue' - the 'Trinity Formula' in Marx's parlance - than Uno recognises. As argued throughout the present volume, the refutation of the Trinity Formula is the pivotal motivation for Marx's criticism of fetishism as method. In the structure of the manuscripts for what would become Capital, Marx primarily targets the theory's classic form, as it has been first formulated by Adam Smith, namely in its sequence labour/wages, capital/profit (interest plus profit of enterprise), land/rent. ${ }^{43}$ Marx quite obviously adheres to this form of presentation in his overall analysis and critique over the three volumes, which demonstrates the centrality of the Trinity Formula's classic form as an object of critique. By targeting the theory's classic form as we find it in Smith, Marx is also able to discuss it in the conventional sequence in which it has come to dominate the economic discourse since the 1770s. The first supposition, namely that labour 'yields' wages, has not only been criticised and analysed by Marx in Volume I, it forms the heuristic basis or the interpretational key to demystify the fetishistic illusion that it is only one among other forms of social wealth. Because abstract human labour, and especially living labour in the context of production, is the only source of wealth in its particularly capitalist social and historical form, it must by logical necessity be analysed first at the level of the analysis of essence. Only afterwards, in accordance with the sequence of the Trinity Formula, is Marx able to show how the notion of capital yielding profit, respectively interest and profit of enterprise, and the notion of land yielding rent, is a fetishism based on the naturalisation of the social

43 'Wages, profit, and rent, are the three original sources of all revenue as well as of all exchangeable value. All other revenue is ultimately derived from some one or other of these'. Smith 1846 [1776], p. 24. 
form specific to capital, in which social production is stripped of its particular character in the form of wage labour and exploitation. This explains why the illusion that labour yields wages is dispersed at the basic level of Marx's analysis. In this sense, at first sight, Marx seems to deviate from his own intent of critically revealing the increasing mystification accompanying the categories of profit, interest, and rent. For is not the category of interest, rather than the theory of rent, where the 'capital relationship reaches its most superficial and fetishized form'?44 For Uno, the discussion of interest as the last category is at least in part explained by this motive. Indeed, the relation of M-C-M' (as in commercial capital) is extinguished to $\mathrm{M}-\mathrm{M}^{\prime}$ in the theory of interest, with its original dependency on the exploitation of alien labour completely removed from sight. To emphasise the importance of interest-bearing capital as 'fetishistic', Uno maintains that the problem of fetishism with regard to the Trinity Formula is less comprehended by the category of rent than by interest. Hence, the theory of rent must precede the theory of interest:

... the so-called ideal (rinen) of capitalist society in the last section on the 'Sources of Revenue' cannot be comprehended in its inner relation from the category of rent. That the character of class relation in capitalist society is obscured (inpei sarete) at the roots of formal commodityeconomic equality and liberty shows most clearly where landed property itself becomes interest-bearing capital. The establishment of capital is completed where land, like capital, becomes commodified and produces interest by itself. ${ }^{45}$

But Uno misses the second feature of Marx's separation of the theory of rent from the theory of interest: Marx's desire to criticise their confusion, which has often overwhelmed classical political economists. This confusion lay either in their attempt to apologetically 'transform the capitalist system of production into a system of "harmonies" (such as Carey)', or to directly 'present interest on capital as a form analogous to ground rent' (Dudley North, Locke) in a time when interest received general social contempt. Uno, like some political economists in Marx's time, therefore also forgets that 'ground-rent can and does exist without the addition of any interest on the capital incorporated in the soil. ${ }^{46}$ Like them, he simply identifies rent with interest-bearing capital.

$44 \quad$ Marx 1981, p. 515.

45 Uno 1974 [1962], p. 288.

46 Marx 1981, pp. 759-6o. 
More generally, Marx's treatment of the theory of the 'three sources of revenue' precisely endeavours to show its heteronomity. Hence, Marx comments that 'the ostensible sources of the wealth annually available belong to completely disparate spheres and have not the slightest analogy with one another. Their mutual relationship is like that of lawyer's fees, beetroot and music'. ${ }^{47}$ With regard to rent's position in the Trinity Formula that Uno claims 'cannot be comprehended ... from the category of rent', it is noteworthy that, by the same token, the notion that 'nature' creates surplus value or profit, is no less fetishistic or illusory than the notion that interest is unhinged from the production process of capital. ${ }^{48}$ And, like the latter, it belongs to the canon of firmly established beliefs of classical economic theories - including that of Smith and Ricardo - which can all be traced back to the notion that labour is not the only source of profit. Hence, Marx's emphasis on the theory of rent is a different one than Uno's. While for Uno, the themes of the 'Doctrine of Distribution' revolve around the distribution of the total social profit between different capitals, in order to elucidate the relationship among capitalists alone, Marx, in his concluding critique of the Trinity Formula, relegates it back to the relation between capital and labour - keeping in mind the prevalence of the labour theory of value as a theory of social form. To show this in every instance of the classic formulation of the theory of the 'three sources of revenue' informs the greater division of Capital Volume III into profit-interest-rent.

$47 \quad$ Marx 1981, p. 953.

48 Marx lists five conditions of the analysis of surplus profit in the chapter on 'Differential Rent in General'. These can be summarised as follows: first, rent is always differential rent, arising from the difference between the individual production price and the general production price for capital in the same sphere of production, 2. ground-rent 'arises from the greater relative returns from certain particular capitals invested in a sphere of production', as compared with capital investments that are excluded from these favourable conditions, 3. 'the natural force is not the source of the surplus profit, but simply a natural basis for it, because it is the natural basis of the exceptionally increased productivity of labour'. The use of natural forces or mechanics, e.g. water power, is directly linked to the appropriation of a greater share of profit contained in the commodities produced with the help of natural powers, but this only makes sense as a characteristic of and within the logic of capital, not as a characteristic of the natural powers, 4 . landed property in the waterfall has in and of itself nothing to do with the creation of the portion of surplus-value (profit) and hence of the price of the commodity that is produced with the aid of the waterfall'. 5 . 'Landed property enables the proprietor to lay hold of the difference between the individual profit and the average profit; the profit captured in this way, which is renewed every year, can be capitalized and then appears as the price of the natural force itself'. Marx 1981, pp. 785-7. 


\subsubsection{Interest (Bank Capital and Commercial Capital/Profit)}

That Uno discusses bank and commercial capital merely as sub-forms of interest - though specifically demarcated ones - highlights one of the formal differences to Marx's conceptualisation. In Marx, the formation of commercial capital is clearly separated and prior to the theory of interest, the latter of which subsumes the analysis of bank and loan capital, in short, the credit system. The clear separation of commercial capital from interest is motivated by Marx's claim that

[i]n interest-bearing capital, the capital relationship reaches its most superficial and fetishized form. Here we have M-M', money that produces more money, self-valorizing value, without the process that mediates the two extremes. In commercial capital, M-C-M', at least the general form of the capitalist movement is present, even though this takes place only in the circulation sphere, so that profit appears as merely profit upon alienation; but for all that, it presents itself as the product of a social relation, not the product of a mere thing. The form of commercial capital still exhibits a process, the unity of opposing phases, a movement that breaks down into two opposite procedures, the purchase and sale of commodities. This is obliterated in M-M', the form of interest-bearing capital. ${ }^{49}$

Two results can be drawn from this observation: first, with regard to the complete conceptual structure, the general emphasis on the fetishistic character of the categories under view in an 'ascending order' - from commercial capital/profit to interest - and second, with regard to the notion of commercial profit alone, commercial profit's appearance as 'merely profit upon alienation'. It is especially the last aspect that gets lost in Uno's conceptualisation of commercial profit. Accordingly, Uno misses the point of Marx's analysis of commercial profit within the structure of Volume III. To begin with, critically engaging Uno's own interpretation against Marx, we must look at Uno's specific understanding of commercial profit within the theory of interest, succeeding the category of bank capital.

On a more general level, for Uno, commercial profit is obtained from the saving of circulation costs of productive capital and must be analysed after the theory of profit and rent, because it does not contribute to the production of surplus value. Bank capital however has a special role in the mediation of com- 
mercial capital - this is what allows it to become an economic factor in the question of circulation costs:

... the influence of the circulation period and the circulation costs on the profit rate, as I have already explained before, does not wait for what Marx calls 'the intervention of commercial capital' via the theory of interest in money capital. It must be clarified through the mediation of commercial capital as bank capital. In other words, 'industrial capitals and the competition between them' itself shortens the circulation period by the advance $(y \bar{u} z \bar{u})$ of money funds as idle money capital which becomes the first problem (mondai). Besides the fact that commercial capital is a precondition for the saving of circulation costs, it also solves the problem of the saving of original circulation costs..$^{50}$

Bank capital advances or accommodates idle money capital to commercial capitalists in order to serve their (only) function as the savers or 'economisers' of circulation costs. They both work hand in hand in the cost-saving and circulation-facilitating process of capitalist valorisation: while bank capital converts idle money-capital necessarily generated by the movement of industrial capital into socially utilisable funds and re-allocates them, commercial capital replaces industrial capitals in the conversion of commodity-capital into money-capital by selling the commodities and therefore 'expediting the hazardous process $\mathrm{C}^{\prime}-\mathrm{M}^{\prime \prime}{ }^{51}$ Bank capital therefore participates directly in the facilitation of the appropriation of profit while commercial capital indirectly participates in it. To justify this interpretation, Uno refers to Marx: 'Marx himself says that "commercial capital first of all abbreviates the phase C-M for productive capital. Secondly, given the modern credit system, it has a large part of the society's total money capital at its disposal, so that it can repeat its purchases before it has definitively sold what it has already bought ..." "52 The role of commercial capital is to abbreviate and save this substantial part of the faux frais of production not only in an accidental, but in a general form:

\footnotetext{
5o Uno $1962[1974]$, p. 296.

$51 \quad$ Uno 1980, p. 113 .

52 Uno 1962 [1974], p. 296. Uno quotes from Marx 1981, p. 419. Marx's original locus for the discussion of the costs of circulation is not in Volume III, but in Volume II, Chapter 6, of Capital. However, in Volume III, 'The Role of Credit in Capitalist Production' is the 'reduction of circulation costs', which however does not fall to commercial capital, but is logically prior in bank capital and credit. Marx 1981, p. 566 .
} 
Commercial capital, in contrast to the social saving of circulation costs through the credit system, eliminates the individual, accidental difference in the shortening of the circulation period by making the direct saving of so-called pure costs of circulation its object. It therefore additionally supports the formation of an average profit rate - by capitalising the costs of circulation itself. ${ }^{53}$

The savings of the circulation costs arising from the function of commercial capital, Uno contends, enter into the funds of variable capital in the productive sector. This is how commercial capital indirectly contributes to the formation of a general rate of profit. In this case, the expenses at the disposal of commercial capital completely reimburse the costs of labour: 'As expenses, the costs of circulation are at once even better saved here than with the labour of the wage workers, and with the part of the savings, it forms the profit of variable capital' ${ }^{54}$ Commercial profit in Uno's reading also generates the 'socalled entrepreneurial profit' which for Marx, together with interest for bank capital, forms a division of profit at the level of productive capital. While for Marx, profit of enterprise can represent either industrial or commercial profit and is therefore dependent on its mode of investment, ${ }^{55}$ for Uno, the relation between commercial capital and profit of enterprise is more closely knit: even if the commercial capitalist is in possession of his own capital stock ( jiko shihon/Eigenkapital), this part of his own capital, like loan capital, is thought to generate interest as capital. The remainder after the subtraction of interestshare from commercial profit by the shortening of the circulation period is then idealised (kannen serareru) as 'profit of enterprise' by his own [the commercial capitalist's] activity. ${ }^{56}$ As we can see, Uno attributes a somewhat positive role to commercial capital and profit, stressing its facilitation of the circulation process and its indirect role in the formation of a general rate of profit.

The emergence of the general profit rate, as we have seen earlier, is one of the three 'laws' (hossoku) of pure theory, now treated in the context of the distribution of profit. Because it supplements the law of value and the law of population (which, as a law of general social equilibrium, is the 'Absolute Foundation of the Law of Value' that governs the totality of capitalist activity), the intermediary function of commercial capital serves as a welcome and important solution to the problem of general social costs that would otherwise

53 Uno 1962 [1974], p. 296.

$54 \quad$ Uno 1962 [1974], p. 298.

55 Marx 1981, p. 496.

$5^{6} \quad$ Uno 1962 [1974], pp. 298-9. 
impede the 'automatic power of self-regulation'57 inherent in the law of value. Marx had allegedly de-emphasised the structurally hampering character of the circulation period and its costs as an impediment to the smooth functioning of capital, so that 'when Capital develops the theory of profit, the treatment of the circulation period is left unclear, so that this point is for the first time considered in commercial capital. But the theory of commercial capital is not clearly solved'.58 For Marx, what is at stake in the analysis of commercial capital is veritably different from Uno's functionalist reading of 'the saving of circulation costs'. Marx, stressing the 'characteristic peculiarities'59 of commercial profit, targets the conventional understanding of commercial profit in his predecessors who have not sufficiently understood its role in the formation of a general profit rate and hence succumb to the illusory notion that commercial capital and profit emerge from the mercantilist notion of 'buying cheap and selling dear'. Solely in order to disperse this illusion, or rather answer the question of how commercial capital 'attract[s] the part of the surplus value or profit produced by productive capital that falls to its share', Marx has written the chapter on commercial capital and commercial profit. Answering this question for Marx also serves as an explanans of the formation of profit at the superficial level of the presentation. Marx's intervention, in contrast to Uno's, is therefore decisively un- if not anti-formalistic: it primarily considers the divergence of appearance (commercial profit as profit upon alienation) and essence (commercial profit's 'parasitic' behaviour in relation to the general rate of profit in production) within the limits of the capitalist mode of production that characterises his critique of fetishism as method. It is therefore also situated at a level of abstraction different from Uno's. While Uno time and again emphasises the relevance of an unhampered circle of production and circulation in which commercial capital serves as an auxiliary means for industrial capital to obtain surplus value (profit) as a whole in order to fulfil the 'absolute' law of value, Marx's emphasis in contrast lies precisely on a critique of the social relation that is value. In other words, the critique of fetishism, in contrast to Marx, is anathema to Uno within the discussion of commercial profit. At this point, we do not intend to repeat the presentation of commercial capital's specific characteristics in fully developed industrial capitalism. Let it however be noted that Marx rejects the notion that 'commercial profit is just a supplement, a nominal increase in the price of the commodities above their value' by showing how it

$57 \quad$ Uno 1980, p. 69.

$58 \quad$ Uno 1962 [1974], p. 297.

59 Marx 1981, p. 379. 
contributes to the formation of the general rate of profit according to the proportion it forms in the total capital. ${ }^{60}$ More tellingly, this presumption follows a remarkable parallel feature to the role of industrial capital: 'Just as industrial capital only realizes profit that is already contained in the value of the commodity as surplus-value, so commercial capital does so only because the whole of the surplus-value or profit is not yet realized in the price of the commodity as realized by industrial capital'.61 Without commercial capital, production prices would be differently adjusted, but commercial capital in turn hinges upon the lowering of the total value of the commodities in order to make profit: 'The merchant's sale price is higher than his purchase price not because it is above the total value, but rather because his purchase price is below this total value, ${ }^{\prime} 6$ i.e. the production price in this segment of production. In other words, because the general profit rate already accounts for commercial capital as an intermediary, pushing down the rate of industrial profit in this segment to obtain its own profit, commerce emerges as profitable at all. But from precisely mistaking the lowering of the purchase price below the total value for a surcharge on total value arises the fetishistic idea of 'profit upon alienation' in the conventional theories of commercial profit. For Uno however, Marx's critique of the mercantilist notion is beyond consideration. Marx's motivation for discussing commercial profit at all remains unconsidered in Uno's reading. Quite to the contrary, like in his general theory of capital discussed in Chapter 2.1, he historically exemplifies industrial capital on the basis of merchant capital, instead of comprehending the former as a complete deferral of the analytical frame of reference with regard to the generation of surplus value:

... I have already mentioned in Part I, Chapter 3, that merchant capital was the first form of capital to develop in history and is the most general form of capital in theory. Thus industrial capital, too, is based on the form of merchant capital. That is why ... industrial capitals are capable of distributing surplus value among themselves as profit, making use of the mechanism of circulation. Yet industrial capitals cannot by themselves go as far as to equalise the burden of circulation costs ... commercial capital ... must relieve industrial capitals of these inequalities by taking over the business of trading commodities. ${ }^{63}$

\footnotetext{
6o See Marx 1981, p. 398, for the detailed calculation.

61 Marx 1981, pp. 399-400.

62 Marx 1981, p. 400.

63 Uno 1980, p. 91.
} 
And yet, Uno considers his reconstruction of Capital as pure theory in the Principles as superior to Marx's. This is shown in another critique of Marx. Uno maintains that 'the unfolding of commercial profit, interest, and rent in Capital is rather conducted in merely external fashion'.64 This objection against Marx's method grows more acute in the latter's distinction between money capitalists and functioning capitalists in the theory of interest. Here is what Marx says about the pivotal distinction between the two kinds of capitalists:

Interest ... originally appears, originally is, and remains in reality nothing but a part of the profit, i.e. surplus-value, which the functioning capitalist, whether industrialist or merchant, must pay to the owner and lender of capital in so far as the capital he uses is not his own but borrowed. If he simply uses his own capital, there is no such division of the profit; it belongs to him completely. In fact, in so far as the owners of capital use it themselves in the reproduction process, they do not compete together to determine the interest rate, and it is clear here already how the category of interest - which is impossible without the establishment of a rate of interest - lies outside the movement of industrial capital itself ... It is in fact only the division of capitalists into money capitalists and industrial capitalists that transforms a part of the profit into interest and creates the category of interest at all; and it is only the competition between these two kinds of capitalists that creates the rate of interest. ${ }^{65}$

In introducing the notion of interest-bearing capital in Chapter 21 of Volume III, Marx gives an example to demonstrate how the money advanced by the money capitalist to the functioning or the industrial capitalist 'receives, besides the use-value which it possesses as money, an additional use-value, namely the ability to function as capital', so that money, in its function of being capital, becomes a commodity: 66

Let us take the average annual rate of profit as 20 per cent. Under average conditions, then, and with the average level of intelligence and activity appropriate to the intended purpose, a machine with a value of $£ 100$ that is applied as capital yields a profit of $£_{2}$ o. Thus a man who has 100 at his disposal holds in his hands the power of making this $£ 100$ into $£ 120$, and thus producing a profit of $£ 20$. What he possesses is a potential capital of

$64 \quad$ Uno 1962 [1974], p. 298.

65 Marx 1981, p. 493.

66 Marx 1981, pp. 459-6o. 
$£ 100$. If this man makes over his $£ 100$ for a year to someone else, who actually does use it as capital, he gives him the power to produce $£ 20$ profit, a surplus-value that costs him nothing and for which he does not pay any equivalent. If the second man pays the proprietor of the $£ 100$ a sum of $£_{5}$, say, at the end of the year, i.e. a portion of the profit produced, what he pays for with this is the use value of the $£ 100$, the use value of its capital function, the function of producing a $£ 2$ o profit. The part of the profit paid in this way is called interest, which is thus nothing but a particular name, a special title, for a part of the profit, which the actually functioning capitalist has to pay to the capital's proprietor, instead of pocketing it himself. ${ }^{67}$

For Uno, the distinction Marx makes between the money and the functioning capitalist is a merely 'pragmatic' and 'arbitrary' one. Pure theory does not imply any relation such that a 'functioning capitalist' should pay $£_{5}$ to a 'money capitalist'. Pure theory, according to Uno, merely supposes capitalists as the 'personification' of capital - which Marx calls 'character masks' - so that the division of capitalists between money capitalists (bankers) and functioning or industrial capitalists is unacceptable within pure theory. Capitalists as personifications of capital only serve the function to produce with their own particular capital a particular surplus value, and, as Uno emphasises, none of this implies the existence of a 'money capitalist'.68 Besides,

why should the latter [the money capitalist] lend his capital to the former 'for one year' only instead of permanently? Even if money does acquire 'the additional use-value, namely that of serving as capital', in order for that money to become a commodity, it must first become a non-use-value to the 'money capitalist'. This important point is completely forgotten in the claim that the presence of the additional use-value by itself converts capital into a commodity. An argument such as this is beyond my comprehension, unless the prior specifications of the nature of commodities, money, and capital in Capital are to be summarily abandoned at this point. In the pure theory of capitalism the concept of a 'functioning cap-

67 Marx 1981, p. 46o. The whole passage is quoted in Uno 198o, p. 120, footnote 2. Sekine uses the Capital edition published with Progress Publishers, Moscow 1965. See Marx 1965. (Sekine wrongly cites 1966 as the publication date).

68 For an elaboration of Uno's critique of Marx's distinction between 'money capitalists' and 'functioning capitalists', see Simoulidis, III Conferencia International La obra de Carlos Marx y los desafios del Siglo XXI, 2006. 
italist' who does not possess a capital of his own is surely unreasonable, even if the concept is proposed to pair off with that of a 'money capitalist.' 69

There are several claims in Uno's rejection of Marx's distinction that we must briefly elucidate in order to understand the misapprehension they express of the form determination of interest-bearing capital. ${ }^{70}$ First, why should the money capitalist indeed lend his capital 'for one year' only instead permanently? Obviously, because the money capitalist, just like the industrial capitalist, is primarily interested in revenue. Revenue however must somehow or other materialise in time. Since interest is nothing but the payment for permission to use a specific amount of capital in order to valorise it in a certain period of time, the money capitalist is right to demand his money back after the exhaustion of this time, based on the law of equivalent change (which, needless to say, must be supplemented by a theory of the rate of interest which however precisely presupposes the existence of competing money capitalists). Of course, money-as-capital may also be lent over and over again by the money capitalist, but even in this case, the very concept of interest demands that it must materialise in reality after the revenue has been obtained by the industrial capitalist. Otherwise, there would be no reason to lend money capital at all.

Second, within pure theory, the assumption that functioning capitalists do not possess their own capital is 'unreasonable'. If we again bring to mind that, in Volume III of Capital, Marx studies the 'The Process of Capitalist Production as a Whole' in the different forms of capital (profit, interest, rent) as they appear at the surface of capitalist (self-)presentation in relation to the increasing obfuscation of the exploitation of living human labour it receives in this order, then interest as a category existing in the reality of the capital relation cannot be abandoned in this systematic intent of Volume III. In really existing capitalist relations, interest, and bank credit deriving from it, precedes industrial profit as a fact. Trivially, that is because - if we exclude inheritance as an epiphenomenon which cannot explain overall new capital investments in the

\footnotetext{
69 Uno 1980, pp. 120-1, footnote 2.

70 Ehara Kei agrees with Uno's claim that the creation of idle money funds in the industrial cycle give sufficient stimulus for the credit system, without a need to refer to 'money capitalists' (Ehara 2017/18. pp. 104-5). But if 'money capitalists', that is, capitalists solely making profit in the sphere of money circulation, exist - and even Ehara would not deny the existence of bankers - we may be well advised to explain their existence. This is, in fact, Marx's motivation, which both Uno and Ehara seem to not find necessary.
} 
complete national and international social context - industrial 'entrepreneurs' do not have their own money to start a business. Hence the credit system. Of course, for Uno, this matter looks different, because he disregards the object of Marx's study in Volume III which is the presentation of the real process of capitalist valorisation at the surface of its self-presentation. In Uno's presentation, in contrast, interest is merely reduced to the formula M-M' which relies on pre-capitalist relations, together with merchant capital, and which both 'now obtain their capitalist-economic explanation, in the light of which their original activities in pre-capitalist societies as well as their surviving operations in capitalist society can be better appreciated. ${ }^{71}$ However, the presentation of their 'operations' would precisely have to include the existence of the money capitalist on the one hand and capitalists on the other. Uno therefore can neither explain the category of interest nor the category of the rate of interest, because 'only the division of capitalists into money capitalists and industrial capitalists ... transforms a part of the profit into interest and creates the category of interest at all; and it is only the competition between these two kinds of capitalists that creates the rate of interest'. At the same time, in Uno's discussion of 'Loan-Capital and Bank-Capital', banking activities are presupposed. Uno's rejection is therefore doubly lopsided: not only does he dismiss Marx's discussion of interest by misconceiving of the mode of presentation in Capital Volume III that implies really existing relations, but he rejects the distinction between money and functioning capitalists and yet presupposes them himself - if, however, only by sleight of hand.

Yet, Uno admits that 'functioning' as well as 'money capitalists' in fact do exist in reality - but pure theory must exclude their existence from its reflection and limit itself to the existence of the capitalist par excellence, i.e. the capitalist as the personification of capital. ${ }^{72}$ This argument shows that Uno has not comprehended the significance of the level of abstraction of Capital Volume II I which treats really existing capitalist relations - and therefore matter-of-factly must also include the analysis of the separation of a part of the capitalist class in 'money', i.e. bank capitalists, commercial capitalists, land owners, and so on. As Uno says clearly enough, the 'relation between capitalists' forms the object of the Doctrine of Distribution. It therefore seems curious not to include the relation between industrial and bank capitalists. Third, for Uno, 'the prior specifications of the nature of commodities, money, and capital in Capital are to be summarily abandoned' if we say that in order for money to become a loanable

$71 \quad$ Uno 1980, p. 109.

72 Uno 1980, p. 121, footnote 2. 
commodity as capital, 'it must first become a non-use-value to the "money capitalist". ${ }^{73}$ But why should the contention that money functions as a use value contradict any of the suppositions developed in the first chapter of Capital Volume I? Money, as the direct incarnation of abstract human labour, even if its use value and value collapse in its fetishistic semblance of being directly value, can - under certain conditions - be transformed into capital. This is nothing new even on the level of Volumes I and II, in which money capital is converted into productive capital. It is, however, odd to maintain that money 'must become a non-use-value': since the twofold character of the labour presented in the commodity (der Doppelcharakter der in den Waren dargestellten Arbeit) is reflected in use value and value, and the exchange of commodities is motivated by value as the social form of labour under capitalist conditions, then Marx's earliest conception also holds for money loaned as capital: it has value for its seller and a use value for its buyer. That it has a value at all for the seller is decisive here. The only modification lies in the fact that the commodity is not entirely sold once and for all, but lent over a certain period of time. But that does nothing to change the initial analysis of value and use value and of the commodity and money in Chapter 1 of Capital Volume I. Uno's formalistic theory of commodity and money as discussed in Chapter 3 comes back with a vengeance in his elaboration within pure theory. Indeed, it is not that the 'prior specifications ... in Capital' must be abandoned, but Uno's interpretation of them. It is remarkable how Uno here indirectly points to the deficiencies of his own interpretation.

\subsubsection{Accumulation as the Reproduction-Process of Capital}

For Uno, the theory of value, the theory of population (discussed within the framework of accumulation and crisis), and the theory of the formation of a general rate of profit form the 'three great economic laws regulating capitalism' (shihonshugi wo kisei suru sandai keizai hōsoku) of capitalism. All of these, as will be discussed in the next chapter, regulate capitalist production insofar as they guarantee the satisfaction of general social demand by the appropriate allocation of labour to different spheres of production. This process serves to secure the reproduction of labour power, understood by Uno as the sine qua non of capitalist sociation. Capitalist accumulation must therefore be primarily understood as the process of the reproduction of labour power. This system of reproduction accordingly presupposes that labour power is always readily available. It therefore simultaneously presupposes a relative surplus popula- 
tion created by a period of 'extensive accumulation'. To generally grasp the relation between business cycles and population theory, let us provide a preliminary summary on Uno's theory of crisis within business cycles (which will be discussed in more detail in Chapter 4.4.):

According to Uno, crisis only emerges in periods in which it cannot absorb the existent supply of labour power. Capital reacts by adopting the measures and techniques to newly accommodate labour. The adoption of these methods take place in the phase of depression in which a successive recovery can be noticed. Because of the employment of new production techniques in this transition from depression to prosperity, cycles of so-called 'extensive accumulation', relative surplus populations can be absorbed. This is generally a phase of prosperity. In effect however, with the increase of the organic composition of capital, a relative surplus population may be formed, introducing another phase of crisis. Accordingly, capital must renew its production techniques to absorb these surplus populations in the next business cycle, so that the succession of business cycles of prosperity, depression, and crisis can newly occur. ${ }^{74}$ The law of population for Uno manifests itself in capital's ability to both produce, but also absorb the relative surplus population: 'This is the manner in which the law of population peculiar to capitalism asserts itself, securing for capital the supply of labour-power required for its accumulation even when the existing stock and the natural growth rate of the labouring population are given and fixed. ${ }^{75}$ For Uno, this law specific to capitalism therefore supplements the theory of the formation of the general rate of profit, as well as the law of value, so that 'everything is to the best in the best of all possible worlds'. These three laws, in other words, characterise the 'self-containment' of capitalist society. In this conception, Uno invites associations with Leibniz's idea of 'pre-established harmony', applied to the capitalist economy. For Uno, accordingly, Marx had put too much stress on the formation of a relative surplus population and too little on its repetitive absorption. Uno therefore certainly has a theory of business cycles, but he lacks a theory of crisis ${ }^{76}$ Needless to say, this perception of the 'capitalist laws' is opposed to Marx's understanding in which the 'law' of value as a historically specific social form is founded on the basic contradiction of the domination of value over use value to systematically create poverty and social oppression. The constant formation of a 'relative surplus population', the

74 Uno 1980, pp. 88-9. In this section of the Principles, Uno provides a basic overview of his crisis theory.

75 Uno 1980, p. 53 .

76 We will return to a more detailed discussion of Uno's theory of the business cycle in Chapter 4.4. 
so-called industrial reserve army, or 'surplus population', on the one hand, with the simultaneous accumulation and concentration of wealth in the hands of a few, is one form where this contradiction is demonstrated in really existing capitalist society.

In order to discuss Uno's contention that Marx's theory of the accumulation process of capital should be subsumed under the theory of reproduction, we must take a preliminary look at Marx's conceptual relation of accumulation and reproduction between Volumes I and II of Capital. Both accumulation and reproduction are discussed in the two volumes, albeit on different levels of abstraction. Before we consider the theory of reproduction, as exemplified in the 'reproduction schemas' of Volume II, let us hear what Marx has to say about the relation of accumulation and reproduction at the beginning of Part Seven, 'The Process of Accumulation of Capital', in Volume I:

On the one hand ... we assume here that the capitalist sells the commodities he has produced at their value, and we shall not concern ourselves with their later return to the market, or the new forms that capital assumes while in the sphere of circulation, or the concrete conditions of reproduction hidden within those forms. On the other hand, we treat the capitalist producer as the owner of the entire surplus-value, or, perhaps better, as the representative of all those who will share the booty with him. We shall therefore begin by considering accumulation from an abstract point of view, i.e. simply as one aspect of the immediate process of production. ${ }^{77}$

In his methodological distinction between the discussion of accumulation within the basic theory of Capital in Volume I and the more detailed discussion in Volumes II and III, Marx notes that ' $\mathrm{t}]$ he detailed analysis of the process [of the reconversion of commodities into capital] will be found in Volume 2', so that 'in the following pages, we shall assume that capital passes through its process of circulation in the normal way'.78 Furthermore, the splitting-up of surplus value into 'various mutually independent forms, such as profit, interest, gains made through trade, ground rent, etc.' will be dealt with 'only in Volume $3 .{ }^{\prime 79}$ Uno is dissatisfied with this order of the exposition:

77 Marx 1976, p. 710. The full passage is quoted by Uno in Uno 1962 (1974), p. 292.

78 Marx 1981, p. 709.

79 Marx 1976, p. 709 . 
I accept that it [the 'detailed analysis of the process' of reproduction in vol. 2] is different from the 'distribution of surplus value'. However, the question is whether 'the detailed analysis of the process' must come later [than the 'abstract point of view']. The analysis of 'The Circulation Process of Capital' in Capital vol. II is also performed 'in the normal way'. What is called the 'detailed analysis' is not a process developed in any unusual way. ${ }^{80}$

For Uno, this understanding suffices to declare the presentation of the accumulation process in Capital Volume I redundant. The reproduction process, and especially the schemas in the third part of Volume II, therefore substitute the demonstration of the basic and abstract process of accumulation presented in Part Seven of Volume I. As a consequence, accumulation is 'sublated' in reproduction, in Uno's overall systematic order. Uno substantiates this claim by lamenting the missing relation between the process of accumulation and the 'law of population' in Marx. However, even the reproduction schemas only insufficiently consider the theory of population which cannot be merely reduced to reproduction guaranteed by the consumption of the means of subsistence. Accumulation, for Uno, is therefore embedded within the circulation process of capital and must be theorised from its vantage point in the 'pure circulation forms' of the commodity, money, and capital:

In the schemas, the reproduction of labour power as a commodity is simply the reproduction of labour depending on the consumption of the means of livelihood by the workers. This does not explain the specific law (hōsoku) in the reproduction of labour power as a commodity ... as the commodity realising sale and purchase through value, being able to assume the form of something that is sold and purchased in separation from its value [i.e. price], and developing the normal 'Reproduction and Circulation of Total Social Capital', including a circulation that is not normal [circulation mediated by price], the 'Accumulation Process of Capital' must be developed first and foremost as something that in its inner structure (sono naibu ni), includes the business cycle that, together with its specific law of population, adheres to crisis. That Marx, beginning Capital with the commodity, did not develop the various forms of the commodity, money, and capital as pure circulation forms, is by far the biggest problem. ${ }^{81}$

8o Uno 1962 [1974], p. 294.

81 Uno 1962 [1973], pp. 294-5. 
A crucial point for Uno in 'The Process of Accumulation of Capital' (Capital Volume I, Part Seven, Chapters 23-5), corresponding to 'Expanded Reproduction: The Actual Process of Capitalist Accumulation' in the Principles, which includes the business cycles and the law of population specific to it, is the availability of additional labour power. This is because, in reproduction on an expanded scale (= accumulation),

additional means of production and livelihood must ... be made socially available by the overall production of capital. Even if they are available in the market, however, capital cannot integrate them into the expanding scale of its reproduction without the simultaneous procurement of additional labour-power. It is, therefore, perfectly clear that the accumulation of capital is crucially dependent on the availability of additional labourpower which capital by itself cannot directly produce. ${ }^{82}$

Marx's presentation of accumulation in Part Seven of Capital Volume I demonstrates an entirely different phenomenon, namely how the 'treadmill-pattern' of accumulation to the contrary necessitates the redundancy of labour. This fundamental contradiction, capital's self-inflicted compulsion to exploit as much labour as possible in the shortest period of time, and the simultaneous repulsion of living labour from the process of production, characterises the inherently crisis-ridden character of capitalist accumulation and production as a whole. Therefore Part Seven of Capital Volume I arguably forms the single most important chapter of all three volumes of Marx's opus magnum. In this Part, Marx shows how and why the theoretical relation of accumulation, reproduction and crisis must be intrinsically subsumed to the problem of the production of surplus value. ${ }^{83}$ The 'law of population' (i.e. the constant formation of a relative surplus population or the repulsion of labour) is therefore the consequence of the 'dictate of capital', the production of surplus value, but not its regulating principle. ${ }^{84}$ In other words, even though the conversion of labour power into a commodity is the sine qua non of capitalist production, it is not its primary motivation, but merely the means to an end - an end which, strictly speaking, is never just 'an end'. The dynamic of surplus value implies only its own augmentation as principle, 'to approach, by quantitative increase, as near as possible

$82 \quad$ Uno 1980, p. $5^{2}$.

83 We will return to this in more detail in Chapter 4.4.

84 For an extensive discussion of Uno's vs. Marx's concept of population and accumulation, see Chapter 2.2. 
to absolute wealth. ${ }^{85}$ While reproduction of the total social capital exhibits exploitation as the basis to this kind of 'wealth', ${ }^{86}$ accumulation demonstrates how both the exploitation of a part of the working class and the 'setting free' of the other part condition one another as the basis of capitalist real subsumption. ${ }^{87}$ Accumulation therefore cannot be subsumed under reproduction or circulation, as Uno would have it. To the contrary, it first of all presents reproduction's condition of possibility in its capitalist form, so that Uno's concept would have to be inverted: accumulation dictates the laws of reproduction, not vice versa. It is therefore treated in its basic mechanism in Volume I of Capital, while the analysis of reproduction on a total social scale is postponed to Volume II. Because Uno fails to see that Marx's theory of value is inherently a theory of crisis, and not a theory of 'business cycles', he also misrepresents the critical intent of both Marx's theory of accumulation and the reproduction schemas. Far from demonstrating a linear, harmonious system of sales and purchases between workers and capitalists, in which the former simply reproduce their labour power by the consumption of 'means of livelihood', the schemas programmatically demonstrate exploitation of surplus labour as the social basis on which reproduction under capitalist conditions takes place. In that sense, the quotes by Uno on the previous page may be misleading: the problem is not that Uno was not aware of Marx's treatment of the inherent relation between accumulation and the 'law of population' as the law of the relative surplus pop-

$85 \quad$ Marx 1976, p. $25^{2}$.

86 The significance of the reproduction schemas in Part Three of Capital Volume InI will be discussed in the next chapter.

87 For accumulation as extreme exploitation and repulsion of the labour force at the same time, see Chapter 25 of Capital Volume I. The following passage clearly recapitulates the inner mechanism necessary for accumulation: 'The production of a relative surplus population, or the setting free of workers, therefore proceeds still more rapidly than the technical transformation of the process of production that accompanies the advance of accumulation and is accelerated by it, and more rapidly than the corresponding diminution of the variable part of capital as compared with the constant. If the means of production, as they increase in extent and effective power, become to a lesser extent means for employing workers, this relation is itself in turn modified by the fact that in proportion as the productivity of labour increases, capital increases its supply of labour more quickly than its demand for workers. The over-work of the employed part of the working class swells the ranks of its reserve, while, conversely, the greater pressure that the reserve by its competition exerts on the employed workers forces them to submit to over-work and subjects them to the dictates of capital. The condemnation of one part of the working class to enforced idleness by the over-work of the other part, and vice versa, becomes a means of enriching the individual capitalists, and accelerates at the same time the production of the industrial reserve army on a scale corresponding with the progress of social accumulation'. Marx 1976, pp. 798-9o. 
ulation: he simply did not agree with Marx's pessimism that capitalism must by principle lead to an ever growing tendency to crisis. ${ }^{88}$ In the next chapter, we will see how, in Uno's understanding, the necessity of crisis can be circumvented in a strange attempt to reconcile the law of value with a theory of general social equilibrium.

\subsection{The Law of Value as the Law of General Social Equilibrium (Uno)}

As we have seen in Chapter 3, Uno's value theory relies on the assumption that the use value of the commodity in the equivalent form motivates exchange relations, even in capitalistically organised 'commodity economies'. In this instance we have argued that Uno neglects the threefold inversion taking place in the equivalent commodity form, namely that a) use value assumes the form of appearance as value, b) concrete labour assumes the form of abstract labour, and c) immediate private labour assumes the inverted form of general social labour. The fetish-characteristic forms that evolve from this inversion of appearance and essence are altogether neglected in Uno's view, especially in his presentation of the use value of a commodity as the incentive for exchange relations between individual commodity owners.

In this section, we will show how this focus on the use value characteristics of social production is further applied to Uno's understanding of capitalist reproduction in general. Social reproduction for Uno must demonstrate the 'Absolute Foundation of the Law of Value', presented in the last section of the 'Doctrine of Production' in Part II. We will further show how the view of value as 'expressing' a balanced relation between production and consumption an 'equilibrium' of the law of value ${ }^{89}$ - delivers a problematic understanding of the creation of surplus value as the necessary basis on which reproduction takes place. It will be argued that although Uno sees 'the sole purpose' of capital as seeking as much surplus value as possible, ${ }^{90}$ he believes this view is compatible with an equilibrium theory of value where supply and demand are necessarily balanced. ${ }^{91}$ In other words: Uno believes in the compatibil-

88 Which is not only implied in the 'Tendency of the Law of the Rate of Profit to Fall' (LTRPF), but already by the analysis of the 'Progressive Production of a Relative Surplus Population or Industrial Reserve Army' (Marx 1976, pp. 781-94).

$89 \quad$ Uno 1980, p. 59.

$90 \quad$ Uno 1980, p. 77.

91 This view has already been pertinently rejected by Paul Mattick. In the capitalist economy, according to Mattick, 'supply and demand never balance'. Mattick 1969, p. 51. The semb- 
ity of a Marxian framework of the self-valorising purpose of capital based on the extraction of surplus with the premise of a 'general equilibrium', serving social need. ${ }^{92}$ Here we cannot only detect a misrepresentation of capitalism as a principally demand-satisfying economic system as in neoclassical economics and especially marginalism, but also a fatal misunderstanding of the law of value that is not exhausted in its forms of circulation. ${ }^{93}$ At their surface, Marx's reproduction schemas in Part Three of Volume II of Capital, based on Quesnay's Tableau Economique, seem to invite an argument for what Meghnad Desai calls the 'long-term survival of capitalism, ${ }^{94}$ or, in Uno's words, the 'self-containedness of the capitalist economic system'. However, if we follow Marx's method to differentiate between the fetishistic appearance of equivalent change between capital and labour, and its contradictory essence - the exchange of non-equivalents, i.e. the exploitation of unpaid alien labour this argument will prove to be misinformed. Part 2, Chapter 3 of the Principles, 'The Reproduction-Process of Capital', presents Uno's own summary of the reproduction schemas we find in Part Three of Capital Volume II. Uno's chapter is further divided into the following sections: 'Simple Reproduction: The Reproduction of Capital and Labour Power, 'Expanded Reproduction: The Actual Process of Capitalist Accumulation', and 'The Reproduction Process of the Aggregate Social Capital: The Absolute Foundation of the Law of Value'. While the first two sections offer little that is controversial within the Marxian framework, the same cannot be said about the last section. After all, here the 'Absolute Foundation of the Law of Value' can finally be proven. Uno's absolute condition for the self-sustainment of capitalist production, that labour-power is made available to it', 95 is again asserted as the 'driving force of the motion of capital' ${ }^{96}$ Social reproduction in general is also bound to be 'anarchistic' in the sense that '[c]apital ... does not produce with a direct knowledge of the

lance of equilibrium is given in the view of 'maximizaton of private interest'. Mattick 1969, p. $5^{2}$.

92 Lebowitz even describes the 'general equilibrium' premise as one of vulgar economy a premise 'contained in its results'. As a construction of 'an apparent totality proceeding from appearance', general equilibrium is 'the highest form of vulgar economy'. Lebowitz 2005, p. 11.

As Ebitsuka Akira approvingly comments: 'In short, the central assignment of Uno's theory of circulation forms is the ability to explain the mechanism of the equilibration of supply and demand in a commodity economy'. Ebitsuka 1982, p. 268.

94 Desai 2002, p. 83.

95 Uno 1980, p. 54.

$96 \quad$ Uno 1980, p. 51. 
structure of social demand: ${ }^{97}$ As Uno however argues, this does not infringe the fact that social reproduction, notwithstanding its 'anarchistic', i.e. blind form, satisfies social need. In fact, the satisfaction of social demand is the necessary logical process by which the circular motion of production and reproduction in the two different departments of production (Department I as the production of means of production and Department II as the production of means of consumption) are guaranteed:

In all societies, the continuation of annual reproduction depends on the distribution of both labour power and the means of production in the two departments (of social production), in accordance with the degree of social demand. This presents nothing but the implementation of the norms (gensoku) existing as a matter-of-fact in the rational process of economic life, and equally pertaining to all societies that assume the commodity form. A capitalist commodity-economy realises this norm through the law of value, which is regulated by and asserts itself in the movement of price. Capital, in other words, provides every sector of production with labour power and means of production in order to, with the given labour time necessary for the production of individual products, satisfy social demand..$^{98}$

For Uno, the accumulation of value and the satisfaction of social demand do not form a contradiction. ${ }^{99}$ However, Uno's view of social reproduction, understood as a transhistorical law, cannot explain the specificities it has in a particularly capitalist society, namely the irreconcilable confrontation of capital and labour and the specifically social form that labour assumes in capitalism namely, as the various value forms. On the basis of this confrontation, reproduction is only possible if exploited, materialised labour in money terms is over and over again thrown back into the circulation process, so that the appropriation of this kind of labour can be repeatedly performed without an equivalent. For Uno, to the contrary, exploitation, or rather, the 'augmentation' of value, is a necessary condition to safely guarantee general social reproduction. A problem

\footnotetext{
$97 \quad$ Uno 1980, p. 55 .

$98 \quad$ Uno 1964, p. 116.

99 For 'balanced growth' theories, see the mostly neo-Ricardian theorisations of Sraffa's technology matrices (see Sraffa 196o), Leontief's input-output tables (Leontief 1986) and the assumptions in neoclassical growth theory, as in Lange 1969, Morishima 1973, Howard and King 1985, Gehrke and Kurz 1995. For a critique on the neo-Ricardian interpretations of Marx's reproductions schemas assuming 'physical quantities of inputs and outputs for the various sectors in the economy', see Moseley 1998a, p. 159.
} 
as to capital's need of accumulation-through-exploitation of human labour is anathema in Uno's presentation of the reproduction schemas. Marx's specific incentive to present the reproduction schemas only in Chapter 20 and 21 of Capita/Volume II is also absent from Uno's considerations. Marx's presentation follows the close criticism of Adam Smith's negligence to discuss the reproduction of constant capital in his theory of the three sources of revenue. ${ }^{100}$ To be sure, in pure theory, the Critique of Political Economy is eclipsed from view. But precisely by declaring it 'outside' of the presentation of pure capitalism's 'laws', Uno fails to see what specifically motivated Marx to conceptualise his central theorems, such as the reproduction schemas. He thereby misses the critical intervention Marx provided and instead substitutes it for a social equilibriummodel in which production necessarily satisfies demand, regulated by the law of value. Yet, nothing could be further from Marx's own intervention. Methodologically, Uno's conceptualisation of social reproduction becomes even more ominous when he discusses it in close proximity to Marx's, using the same figures as him to illustrate his example. To explain, we shall therefore take a closer view at Uno's (mis-)appropriation of Marx's reproduction schemas. Mainly, Uno's contention that accumulation must be subsumed under the theory of social reproduction to demonstrate the law of value as a law of social equilibrium will be critically evaluated. In direct connection, this evaluation will be complemented by a critical analysis of the role of use value in reproduction. Lastly, this chapter concludes by showing how Ricardo has already conceived of the reproduction of labour power merely in terms of use value - thereby attempting to highlight yet another convergence of Uno's thought with nonMarxian political economy, as has previously been indicated with the comparison to Bailey's functionalist understanding of value.

100 Fred Moseley has persuasively argued that Marx's presentation of the reproduction schemas was basically motivated by his critique of Adam Smith's view that 'the price of the total social product is entirely resolved into revenue, that is, into wages plus profit and rent', thereby forgetting the recovery of constant capital (means of production) as money capital in annual reproduction. See Moseley 1998a, p. 16o. The context in which the schemas appear is Marx's critique of the Trinity Formula discussed in the previous chapter (Chapter 19 of Volume II of Capital) that centrally informs Marx's critique of fetishism. While this motive escapes Uno's view, it can at least be said that Uno, unlike the theorists of 'physical inputs and outputs' that Moseley targets in this essay, conceives of the inputs and outputs in monetary terms, using the same figures as Marx. As a matter of fact, however, Uno still misconceives of Marx's schemas as presenting a theory of general equilibrium. 


\subsubsection{Uno's Appropriation of Marx's Reproduction Schemas: The Compatibility of Accumulation with 'Social Equilibrium'}

Because Uno insists that ' $\mathrm{t}$ ] he law of value becomes an economic law because it has the power to realise a general economic norm on a society-wide scale,,101 he can also argue that '[e]ach individual capital satisfies part of the social need while merely aiming at the augmentation of value guided as it is by the motion of prices.' ${ }^{102}$ Here, Uno's view as to the compatibility of the law of value, directed at the exploitation of surplus labour, with an equilibrium of supply and demand becomes clear. He goes on to provide, in accordance with Marx's schema of Simple and Extended Reproduction in Chapter 20 and 21 of Volume II, schematic examples of reproduction to show that a) for the case of simple reproduction, 'the sum of the variable-capital component (and) of the surplus-value component of the outputs of the first sector should be equal to the constant capital component of the output of the second sector', so that I $(\mathrm{v}+\mathrm{s})=\mathrm{IIc}$, while b), for expanded reproduction, I (v+s) > IIc. ${ }^{103}$ Here, in the case of extended reproduction, where the surplus product of both departments is not entirely consumed by the capitalists, but accumulated for the next cycle of production, he again gives nearly the same figures as Marx. ${ }^{104}$ What is decisive is that these schemas are entirely in terms of money circulation, and that particular sums of money are on the one hand required to circulate the capital of $\mathrm{c}+\mathrm{v}$, and another sum is required to circulate s. ${ }^{105}$ To argue for a), Uno uses the same figures as Marx. ${ }^{106}$ Accordingly, Uno supposes the following value composition of $\mathrm{c}$ (constant capital component), $\mathrm{v}$ (variable capital component) and $\mathrm{s}$ (surplus value component), at an exploitation rate of $100 \%$ : Department of Production I (Means of Production): I. $6000=4000 \mathrm{c}+1000 \mathrm{~V}+1000 \mathrm{~s}$, Department of Production II (Means of Consumption): II. $3000=2000 \mathrm{c}+500 \mathrm{~V}+$ $500 \mathrm{~s}$.

\footnotetext{
101 Uno 1980, p. 69, footnote 12.

102 Uno 1980, p. 55.

103 Uno 198o, p. 56. It must be noted that Marx's schemas operate at the level of labour values, not price. This important distinction for the level of presentation is eclipsed in Uno's presentation.

104 Marx 1978, p. 581 ff.

105 For a detailed summary of the rule of $\mathrm{I}(\mathrm{v}+\mathrm{m})=\mathrm{II} \mathrm{c}$ to guarantee simple reproduction, see Marx 1978, pp. 473-4. Moseley strongly argues this point: 'Marx's analysis ... has nothing essential to do with the physical quantities of inputs and outputs, but instead has to do with the advance, recovery and reproduction of different components of money capital throughout the capitalist economy through the purchase and sale of commodities'. Moseley 1998, p. 16o.

106 Uno 1980, p. Marx 1978, p. 473.
} 
If, by the condition of simple reproduction that capital in the next production cycle must only be able to produce with the same capital value as before, the surplus value components are entirely consumed by the capitalists of both departments, then the value $2000(=1000 \mathrm{v}+1000 \mathrm{~s})$ of both I and II must be consumed by those workers and capitalists in the form of consumption commodities of II. In consequence, the capitalist of II has substituted the value of his (II's) constant capital through the consumption of the capitalists and workers of I. Hence, production can start anew with the same value composition of capital: for I: $4000 \mathrm{c}+1000 \mathrm{v}$; for II: $2000 \mathrm{c}+500 \mathrm{v}$. Therefore, the formula for simple reproduction must be I $(\mathrm{v}+\mathrm{s})=\mathrm{II} \mathrm{c}$. At the same time, the money value of the $v$ in department $I$ is substituted with the money value the capitalists of II spend on means of production. Uno disregards this latter point and with it the fact that the money value advanced by the capitalists of both sectors to circulate their value product flows back to them. ${ }^{107}$ If however we assume expanded reproduction in which the surplus is not entirely consumed by the capitalists, we get the following value composition as the initial schema for extended reproduction in $b$ ):

$$
\begin{aligned}
& \text { I. } 6000=4000 \mathrm{c}+1000 \mathrm{v}+1000 \mathrm{~s}, \\
& \text { II. } 225 \mathrm{O}=1500 \mathrm{c}+375 \mathrm{~V}+375 \mathrm{v},
\end{aligned}
$$

the sum being 825 , less than the 9000 in schema a) of simple reproduction.

Uno's figures here only slightly deviate from Marx's. ${ }^{108}$ In his presentation of extended reproduction, Marx has deliberately chosen a smaller sum than in the initial schema to show that 'reproduction on an expanded scale ... has nothing to do with the absolute size of the product, that for a given volume of commodities it simply assumes a different arrangement of a different determination of the function of the various elements of the given product ... It is not the quantity, but the qualitative character of the given elements of simple reproduction that is changed, and this change is the material precondition for the ensuing reproduction on an expanded scale.109 Accordingly, if extended reproduction requires a greater value product of $\mathrm{v}+\mathrm{s}$ in department $\mathrm{I}$ than that of $\mathrm{c}$ in department II, then the formula for extended reproduction must be I ( $\mathrm{v}$ + s) > II c. To prove this, Uno gives the following argument: first, for extended reproduction to take place, the capitalists of I do not spend all of Is on products

\footnotetext{
107 See Marx 1978, p. 477 .

108 In Marx, the v and s of II are 376 , respectively, so that the total value product $=8252$. See Marx 1978, p. 581.

109 Marx 1978, p. $5^{82}$.
} 
of consumption, but withdraw a part of it from the surplus. For example, they keep or accumulate half of it (= 500 s) for the next production cycle with the value composition of 4:1. With the relation of 4:1 transferred to the newly added capital of 500 from the surplus of $\mathrm{I}$, in this department $400 \mathrm{c}$ are added to the original $4000 \mathrm{c}$, and $100 \mathrm{v}$ are added to the original $1000 \mathrm{v}$. In this case, as in the schema of simple reproduction, since I $(1000 \mathrm{v}+500 \mathrm{~s}+100(\mathrm{~s}) \mathrm{v})=\mathrm{II} 1600$, department II must transform not only 1500 , but 1600 into its $c$. If the same capital composition 4:1 is to be maintained in department II as well, then its c must increase by 100 , and the $v$ component must increase by 25 , so that the accumulation required from surplus value in this sector will be $125 \mathrm{~s}$. To summarise:

I. $4000 \mathrm{c}+400(\mathrm{~s}) \mathrm{c}+1000 v+100(s) v+500 s$, $1500 c+100(s) c+375 \mathrm{v}+25(\mathrm{~s}) \mathrm{v}+250$ s. ${ }^{110}$

Accordingly, the composition of productive capital in the two departments newly consists in:
I. $4400 \mathrm{c}+1100 \mathrm{~V}$,
II. $1600 \mathrm{c}+400 \mathrm{v}, 11$

and the value composition of the new productive capital is:

$$
\begin{aligned}
& \text { I. } 4400 \mathrm{c}+1100 \mathrm{v}+1100 \mathrm{~s}=6600 \\
& \text { II. } \quad 1600 \mathrm{c}+400 \mathrm{v}+400 \mathrm{~s}=2400
\end{aligned}
$$

In this case, the scale of a newly commencing production cycle is extended, compared to the first cycle, even though the value sum of productive capital of both departments is the same as with simple reproduction (=90oo). In the present cycle therefore, half of the surplus product being accumulated, the capital value is already reimbursed, so that the resulting production, all other conditions being equal, can start anew with a capital of 9000 (I. 440oC +1100 $\mathrm{v}+1100 \mathrm{~s}=6600$ and II. $1600 \mathrm{c}+400 \mathrm{v}+400 \mathrm{~s}=2400 ; 6600+2400=9000)$. For extended reproduction to take place, therefore, the condition must be satisfied that the value product of the first sector $\mathrm{I}(\mathrm{v}+\mathrm{s})$ is greater than the constant capital of the second sector or department, so that I $(v+s)>$ II $c$. With the above

\footnotetext{
110 Uno 1980, p. 56. The figures in italics indicate that these are exchanged, according to I $(\mathrm{v}+\mathrm{m})=\mathrm{II} \mathrm{c}$.

111 Uno 1980, p. 57. Uno uses the same figures as Marx.
} 
schema, and on the condition that real accumulation now proceeds on this basis, and produces with the accumulated capital, in the following year we get:

$$
\begin{aligned}
& \text { I. } \quad 6600=4400+1100 v+550 s+440(\mathrm{~s}) \mathrm{c}+110(s) v \\
& \text { II. } \quad 2400=1600 c+400 \mathrm{v}+200 \mathrm{~s}+160(s) c+40(\mathrm{~s}) \mathrm{v},
\end{aligned}
$$

so that the composition of capital becomes, for I. $4840 \mathrm{c}+1210 \mathrm{v}$, for II. $176 \mathrm{o} \mathrm{c}$ $+440 \mathrm{v}$, in which case the resulting total value of this production cycle will be 990o, in the following composition:

I. $4840 \mathrm{c}+1210 \mathrm{v}+1210 \mathrm{~s}=726 \mathrm{O}$
II. $\quad 1760 \mathrm{c}+440 \mathrm{v}+440 \mathrm{~s}=9900$.

And this is as true as far as the maths goes - for both Uno and Marx. For Uno though, the expanded reproduction schemas show a perfect, if hypothetical, balance of the inter- and intrasectoral exchanges, so that the schemas 'aim at nothing more than to show that capitalist society too satisfies, albeit in the particularly commodity-economic form, the fundamental condition of simple and expanded reproduction which all societies must satisfy'.12 Under unchanging conditions therefore, this balance invites the hypothesis that the law of value regulates, and indeed, guarantees a stable equilibrium of supply (expressed in the act of sale of one part of the value product) and demand (expressed in the act of purchase in one part of the value product), or as C-M-C'-M'-C"M", etc. Indeed, the equilibrium of supply and demand is nothing short of the 'basic requirement for a commodity economy'.113 For Uno, extended reproduction only requires an 'incremental production of the means of production'114 as a precondition. In contrast to Marx, therefore, Uno believes that the circulation of a surplus product is not based on the extraction of surplus labour - or rather, only insofar as capital must satisfy the needs of the consuming workers by their own product, namely as use value. While it is not the case that Uno disregards exploitation - though he rarely makes use of the term - he clearly sees a structural compatibility of the extraction of surplus labour with the commodityeconomic general laws of aggregate social reproduction, in order to guarantee social equilibrium:

\footnotetext{
112 Uno 198o, p. $5^{8 .}$

113 Uno 1963, p. 76, quoted in Ebitsuka 1982.

114 Uno 1980, p. 57.
} 
The consumption of labour-power is labour itself which produces a new value-product $\mathrm{v}+\mathrm{s}$ in excess of $\mathrm{v}$. In a capitalist commodity-economy, however, even this human relation involving labour-power conforms to the peculiar rules of that economy by the 'commoditisation' and reification of labour-power; it is this conformity that endows the aggregate reproduction-process of a capitalist society with its characteristically commodity-economic regularity. ${ }^{115}$

What we find here is an interpretation of the reproduction schemas that sets them within the idea of the pre-established harmony also conceived in Smith's 'invisible hand': while individual capitals seek to maximise their profits, they do so only for the benefit of the social reproduction of all. Or, in Uno's words:

Each individual capital satisfies part of the social need while merely aiming at the augmentation of value guided as it is by the motion of prices. ${ }^{116}$

And:

... capital possesses the faculty of allocating itself to the various spheres of production so as to supply all the products that society demands. ${ }^{117}$

Again, this view of the reproduction schemas sets them within the idea of pre-established harmony in which precisely those use values are supplied that are needed for consumption while those values are reproduced that are again needed for reproduction. This can only be guaranteed by the governance of the law of value, understood as Say's Law, according to which 'a product is no sooner created than it, from that instant, affords a market for other products to the full extent of its own value.'118 In this sense, production 'supplies' its own demand in equal quantities, and demand 'provides' production with its incentive. Consequently, for Uno (as for Say), 'no general over-production of commodities is theoretically possible'.19 In general, rather, the activities of 'individual capitalists' and 'individual labourers' are 'merely compelled by the law of value which, asserting itself in the motion of prices, regulates the individual pursuit

\footnotetext{
115 Uno 1980, p. 61.

116 Uno 198o, p. 55.

117 Uno 1980, p. 76.

118 Say 1834 [18०3], p. 138.

119 Uno 1980, p. 121.
} 
of private interests.'.120 Uno strangely seems to believe that individual labourers kill two birds with one stone: while they produce the material basis for reproduction - that is, for profit - they pursue their 'private interests' in the simultaneous production of their own means of subsistence. Indeed, to explain capitalism as a self-sustaining system with this strange amalgamation of classical (Smith's invisible hand, Ricardo's focus on the reproduction of labour power in terms of use value) and neoclassical (marginalist) assumptions, in combination with Leibnizian metaphysics, is to obscure precisely the social form that labour takes in its direct confrontation to capital - which Marx's reproduction schemas demonstrate. The view of social reproduction consisting in equilibrium has already been pertinently rejected by Paul Mattick. In the capitalist economy, according to Mattick, 'supply and demand never balance.' ${ }^{121}$ However, the semblance of equilibrium is given in bourgeois economic theory's view of 'maximisation of private interest': '... market relations assure to each and all the equivalent of their particular contributions to the production process, and that is precisely the maximization of private interest which leads to the optimum of social well-being.' ${ }^{122}$ As we have seen, Uno implicitly shares this axiom with bourgeois economists. However, as Marx notes, this would only work if 'private interests were not already socially-determined private interests, whose realization depended on social conditions and on the means provided by these conditions, as well as on their reproduction requirements.'.23 That is, not the 'regulatory power' of supply and demand indicates the regulatory operation of the law of value, but the conditions and limits of production 'regulate' general social supply and demand (which is not tantamount to 'equilibrium'). Mattick:

... market relations are essentially derivative, circumscribed as they are by the capacities and limitations of the production process. Because it is impossible in practice to separate the production process from the circulation process, the effects of the increasing productivity of labor upon the basic production relations as value relations appear only in the modified form of price and profit relations determined by the competitive supply and demand mechanism. But the fact that market relations can only be price relations in no way alters the primary fact that the supply

\footnotetext{
$120 \quad$ Uno 1980, p. 59.

121 Mattick 1969, p. 51.

122 Mattick 1969, pp. 51-2.

123 Marx 1953 [1857-8], p. 74. Emphasis added and quoted in Mattick 1969, p. 52, who also provides his own translation. See Marx 1973, p. 156.
} 
and demand relations are circumscribed by social production relations and the character of social production as the accumulation of capital. ${ }^{24}$

The semblance of equilibrium in terms of supply (in Uno's terms: what 'society' produces) and demand (in Uno's terms: the means of subsistence for the reproduction of labour power) is a consequence of its social constituents in terms of the relation between capital and labour: because only when 'market demand is one that will assure the realization of surplus-value by way of capital expansion,',125 can we rightfully speak of demand. ${ }^{126}$ There is indeed nothing natural about it, as the ahistorical and unspecific notion of 'supply and demand' suggests. Accordingly, crisis occurs, not because the law of value 'breaks down' in regulating supply and demand, but precisely because supply and 'demand' depend on the rate of accumulation, i.e. conditions inherent in production, as the independent variable. The breakdown of equilibrium is one of valorisation's most eminent features. However, there are restrictions to the perfect equilibrium that the law of value regulates, even for Uno: '... if a commodity is over-produced, a fall in its price compels a contraction of the scale of its production; if a commodity is underproduced, a rise in its price induces an expansion of the scale of its production. Hence the labour-time required for the production of each commodity cannot diverge very far from that which is socially normal. ${ }^{127}$ What is 'socially normal' however is tautologically defined by the law of value: general social reproduction expressed in an equilibrium of inputs and outputs for Uno obeys the law of value while the equilibrium, simultaneously, 'demonstrates' the law. With this circular assumption, Uno's thesis of an equilibrium theory of value is completed: 'In other words, the law of value must apply to the whole of society in enforcing the general economic norm of reproduction. The relation between the two sectors expresses an "equilibrium" of the law of value in this sense.'.128 This view is wrong in two aspects: first, as previously stated, it ignores the impetus of capitalist (re-)production whose goal is not the satisfaction of needs by use values, but the accumulation of surplus value (profit). This also delegitimises Uno's appeal to equilibrium, since

\footnotetext{
124 Mattick 1969, p. 53.

125 Mattick 1969, p. 56.

126 Mattick however forgets to mention the bogus concept of 'supply and demand' in terms of its naturalisation. It is never demand that assures the realisation of surplus-value, but moneyed demand.

127 Uno 1980, p. 59.

128 Ibid.
} 
[the] very necessity of evening-up presupposes the imbalance, the disharmony and hence the contradiction ... if it is the tendency of capital to distribute itself in the correct proportions, it is just as much its necessary tendency to drive beyond the correct proportion because it strives boundlessly for surplus labour, surplus productivity, surplus consumption, etc. ${ }^{129}$

Second, Uno's use value-based view of social reproduction leads to a circular view of the concept of value, according to whose 'law' supply and demand regulate the market value in the last instance, while the law of value depends on its expression in a market value directly regulated by the dynamics of supply and demand. The first view permeates Uno's theory of value as a whole, while the second is a specific symptom of Uno's developed value theory that oscillates between explaining an objective law that governs exchange relations, or a merely regulative force, ultimately suspended in the notion of market values explaining price fluctuations of commodities as the products of capital in the market:

... the social regulation of the activity of individual capitals by means of the conversion of values into production-prices results in a definitive quantitative relationship between the means of production and materials for consumption such as is exhibited in the schemes, and confirms the law of value by ensuring the feasibility of social reproduction. ${ }^{130}$

The determination of values presupposes the adjustment of supply according to social demand, and the mechanism of this adjustment actually develops only when commodities are supplied as products of capital ... Only after the establishment of the notion of market value as the centre of gravity of the market price of a commodity in general, can this notion be applied to the case in which the commodity is a product of capital. ${ }^{131}$

Both aspects, however, are part of a wider symptomatic problem in Uno's version of the pure theory of capitalism: they both ignore Marx's crucial aspect, namely that the distribution of the aggregate surplus over the two departments, and hence, the 'perfect balance' of reproduction, is defrayed by the exploitation of labour power so that the repository of surplus value 'does not cost anything

129 Marx 1986 [1857-61], p. 340.

130 Uno 1980, p. 93, footnote 6. Emphasis added.

131 Uno 1980, p. 93, footnote 7. Emphasis added. 
to its appropriators.' ${ }^{132}$ The law of value is therefore not a theory of equilibrium, quite to the contrary: it shows that reproduction under the conditions of capitalist production ${ }^{133}$ necessarily implies the creation of a surplus via exploitation, a surplus that 'costs the capitalist class nothing' ${ }^{134}$ Therefore, for Marx, the question is not: how does the aggregate annual reproduction process, the inputs and outputs between the two departments, continuously reconstitutes a balance? The question at stake for Marx rather is: 'How is it possible for each capitalist to withdraw a surplus-product from the annual product in money, i.e. to withdraw more money from the circulation sphere than he cast into it ${ }^{135}$ - and all of that 'without an equivalent'? 136 In order to answer this question - probably the most crucial question in the context of the basic theory of capitalist circulation at all - Marx organises his analysis in the following way: first, he considers the exchange between the two departments I $(v+s)$ against II $c$, second he analyses the exchange within department II ('Necessary Means of Subsistence and Luxury Items'), and third, he considers the mediation of the exchanges by monetary circulation. The still unresolved reproduction of the constant capital of Department I is discussed in the next section, the reproduction of variable capital and surplus value in the successive one, and in the last chapter, where the exchange of constant capital in both departments is discussed.

As to how simple reproduction already guarantees that the capitalist withdraws more money from circulation than he initially cast into it, the section on 'The Mediation of Exchanges by Monetary Circulation'137 is especially informative. To these, Marx applies the schema I. $6000=4000 \mathrm{c}+1000 \mathrm{v}+1000 \mathrm{~s}$ and II. $3000=2000 \mathrm{c}+500 \mathrm{v}+500 \mathrm{~s}$. In the following, Marx shows how all the single constituents of value are replaced and a surplus value is still obtained from this process, whether in commodities or in money. To give an example, Marx assumes the capitalist of Department I as a case in point:

\footnotetext{
132 Marx 1978, p. 572.

133 As shown in Chapter 2 of this volume, Uno treats the law of value as a transhistorical law, and capitalism just as an instance of it.

134 Marx 1978, p. 550. Notice the emphasis Marx puts on this fact in Marx 1978, pp. 550-1. See also Clarke: 'It is not simply [the distinctive feature] that the motive of the capitalist is to produce values in order to appropriate a profit. The decisive point is that of the means by which the capitalist is able to appropriate a profit'. Clarke 1994, p. 281. Emphasis added.

135 Marx 1978, p. 549.

136 Marx 1978, p. 55o. 'It is important ... to realise, contrary to a long interpretative tradition, that in Marx the schemes of reproduction have nothing to do with a picture of a "balanced economic growth"'. Bellofiore 2018, p. 382.

Marx 1978, pp. 487-97.
} 
As far as the department I capitalists are concerned, with respect to the component $\mathrm{v}+\mathrm{s}$ of their commodity product they withdraw more money from the circulation sphere than they cast into it. Firstly, their $£_{1,000}$ of variable capital returns to them; secondly, they sell means of production for $£_{500}$ [(Department II buys means of production from department I for $£_{500}$, i.e. commodities worth $£_{500}$ )], and this enables them to convert half their surplus-value into cash; then they again sell a further $£_{500}$ of means of production ([Department II uses $£_{5}$ oo to buy means of production from department I; i.e. commodities worth $£_{5}$ oo]), the second half of their surplus value, and as a result their entire surplus-value has been withdrawn from circulation in the money form. We have therefore, in succession, (1) variable capital transformed back into money, £ 1,ooo; (2) half of the surplus-value realized, $£_{5}$ oo; the other half of the surplus value, $£_{5} \mathrm{OO}$; a total realized of $£_{1, \mathrm{OOO}}+£_{1}$, OOOS $=£_{2}$, ooo. Even if department I cast only $£ 1,000$ into circulation (we leave aside here the circumstances that mediate the reproduction of I c, which will be considered later) ${ }^{138}$ it has withdrawn twice the amount. Of course, the s that has been realized (transformed into money) immediately vanishes again into someone else's hands (department II), because money is exchanged for means of consumption. The capitalists of department I have withdrawn only as much in money as they cast in commodities. The fact that this value is surplus-value, and costs the capitalists nothing, in no way alters the value of the commodities themselves; it is therefore completely immaterial, as far as the exchange of values in commodity circulation is concerned. 139

What we notably find here is the phenomenon that 'it is the money that department I itself cast into circulation that realizes its own surplus value..$^{140}$ It is not difficult to see how the apparent exchange of equivalents is compatible with the more essential nexus of exploitation, so that the exploitation and appropriation of surplus labour becomes the basis on which general social reproduction can take place in a capitalist economy. Uno is disinterested in this historically specific feature of capitalist reproduction, instead declaring reproduction 'the basic economic norm that is common to all societies'. More eminently, for Marx, it is the question of appearance vs. essence that guides his critique as a critique of fetishism. Uno's research question not only differs in this regard

\footnotetext{
138 See Marx 1978, pp. 498-501.

139 Marx 1978, pp. 493-4.

140 Marx 1978, p. 495.
} 
from that of Marx, but falls behind its critical impetus. But it is precisely the 'fallacy of everyday notions' - more concretely, how the general social reproduction process, based on the extraction of surplus value, can appear as a process of equivalent exchange, that interests Marx. Uno's research programme, disregarding the nexus between the essence of the capital relation and its necessary forms of appearance, is explicit in his presentation of 'The Absolute Foundation of the Law of Value' in the reproduction schemes that in Uno's view enacts the 'automatic power of self-regulation. ${ }^{141}$ How important indeed for Marx the contrast between the appearance and the essence of these schemes is, is not addressed only in Marx's critique of Smith's and Tooke's reproduction theories. Let us consider the following, more general point discussed towards the end of the chapter on Simple Reproduction:

... if the capitalist class casts a certain sum of money into circulation in the shape of revenue, it appears as if it paid an equivalent for this part of the total annual product, and that this has thereby ceased to represent surplus value. But the surplus product in which the surplus-value is represented costs the capitalist class nothing. As a class, it possesses it and enjoys it free of charge, and the monetary circulation cannot alter this in any way. The change that this brings about simply consists in the fact that each capitalist, instead of consuming his own surplus product in kind, for which in most cases it would not be suitable, withdraws commodities of all kinds from the total stock to the amount of the surplus value that he appropriated, and appropriates these ... If the capitalist not only withdraws surplus value from the commodity market in the form of commodities for his consumption fund, but at the same time the money with which he buys these commodities flows back to him, he has evidently withdrawn the commodities without an equivalent. They cost him nothing, even though he pays for them with money. ${ }^{142}$

It is the dialectic of the last sentence - that the surplus with which the capitalist obtains more money 'cost(s) him nothing, even though he pays for (it) with money' - and its far-reaching consequences that are eclipsed from Uno's view of a theory of a purely capitalist society.

This also resonates with Brentel's trenchant critique of the 'proportionality'view of Proudhonism entering into Uno's conception. In Proudhon, as Bren-

\footnotetext{
141 Uno 1980, p. 69.
}

142 Marx 1978, p. $55^{\circ}$. 
tel points out, the harmonist semblance of circulation becomes the ground/ reason (Grund) for value constitution. Labour values, which are already constituted (in the process of production) are legitimised by the fiction of harmonious exchange.' ${ }^{143}$ He comments:

In fact, what happens is the exact opposite: what, for Marx, is revealed by the analysis of the capitalist relations of production is that the Proudhonist 'constitution' of value objectivity in reality does not refer to any kind of proportional relation of exchange. Quite the opposite: only the constantly disproportional relations of production and consumption, the disproportional distribution of total social labour across the different productive sectors and their equilibrating movement by the competition of capitals [demonstrate how] the fluctuating relations between supply and demand constitute an objective, viz. objectifying labour value as the average determination of the movements of price. The law of value is real only insofar as it is a law of disproportionality, not of proportionality. ${ }^{144}$

In the following, we will focus on the 'automatic power of self-regulation' (Uno) of capitalist production - a form of its proportionality - that Uno sees guaranteed precisely by the limitations set upon value production by the use value aspect of commodities - and how he takes Marx as a buttress for this view.

\subsubsection{Use Value as 'Passive Constraint' to Equilibrium}

In an important explanatory note ${ }^{145}$ to support his thesis of the inter-sectoral equilibrium being regulated by the law of value, Uno admits to a 'passive constraint' in the power of the law of value 'to realise a general economic norm on a society-wide scale. ${ }^{146}$ This constraint is represented by use value:

... it would be completely incorrect to assert that the reproduction of a capitalist society follows the numerical relation of the schemes exactly or that the schemes can possibly represent an unbalanced development of the relation of reproduction in a capitalist society. Such misapprehensions would deny the automatic power of self-regulation inherent in a capitalist commodity-economy, and would neglect the fundamental rationale that makes the theoretical treatment of capitalism possible

\footnotetext{
143 Brentel 1989, p. 221.

144 Brentel 1989, p. 221.

145 Uno 198o, pp. 68-9. Note 12.

146 Uno 1980, p. 69.
} 
(sic). The wrong interpretations and the misuses of the reproduction schemes based upon such misapprehensions are still prevalent among many Marxist economists. It appears that they misunderstand the nature of the law of value: its peculiar form of application to a capitalist economy, and the restriction imposed on the working of the law by the use-value aspect of the commodities. ${ }^{147}$

We are yet again confronted with Uno's fundamental (mis-)understanding of the value relation, namely that capitalist production, viewed as a whole, produces for, and according to, 'consumer needs' or use value. His reasoning is based on the immediate translation of forms of appearance - that workers in general reproduce themselves as consumers - into a conceptual scheme, that of use value, which is hypostasised as a structural impediment to capital's full self-realisation. To quote the Uno School follower John Bell, 'there was always some use-value and human resistance that capital's impersonal market could not overcome simply by applying its "dull composition" on capitalists and workers alike.' ${ }^{148}$ In our context, Uno takes Marx's considerations of the proportions between necessary and surplus labour and its 'subjective' and 'objective' conditions in agricultural reproduction as buttress to confirm his view. In Capital Volume III, in his discussion of ground-rent being 'surplus-value, the product of surplus-labour', Marx says the following (quoted by Uno):

But, if the use-value of individual commodities depends on whether they satisfy a particular need, then the use-value of the mass of the social

147 Uno 1980, p. 69. Italics in the original.

148 Along with Sekine, John R. Bell is arguably the most outspoken supporter of the idea of 'use value resistance' (Bell 2009, p. 9). Sekine uses this theorem to explain the impossibility of real historical capitalism to operate 'purely', i.e. as the capitalist class 'would have it' (Sekine 2001, pp. 37-9). According to Bell, in theorising capitalism, 'we must fully contrive an "idealized use-value space" in theory, wherein capital can perform its own abstractions without being impeded by external contingencies (such as intractable collective human, use-value or natural resistance) which would be sufficiently powerful that capital could not overcome them by its autonomous and impersonal operation'. Bell 2009, p. 8. The idealisation of an ideal use value space which obstructs the pure workings or 'self-realisation' of capital is problematic in its own ideological implications which will be discussed in Chapter 5.3. It is difficult to see how this 'infringement' of pure capitalism by use value resistance pares with the equally important premise of capitalist economy as a 'self-defining', 'self-regulating' and 'self-expanding' system. Even if it only applies to 'pure capitalism', one would have to define the methodological means by which we can differentiate the one from the other (which the Uno School abstains from doing). 'Method copying', as suggested by Sekine, is begging the question. 
product depends on whether it satisfies the quantitatively definite social need for each particular kind of product in an adequate manner, and whether the labour is therefore proportionately distributed among the different spheres in keeping with these social needs, which are quantitatively circumscribed ... The social need, that is, the use-value on a social scale, appears here as a determining factor for the amount of total social labour-time which is expended in various specific spheres of production. But it is merely the same law which is already applied in the case of single commodities, namely, that the use-value of a commodity is the basis of its exchange-value and thus of its value. This point has a bearing upon the relationship between necessary and surplus labour only in so far as a violation of this proportion makes it impossible to realise the value of the commodity and thus the surplus-value contained in it. ${ }^{149}$

This quote deals especially with the proportion of necessary and surplus labour as condition for the realisation of value: that the direct producers must not only perform surplus labour, i.e. more time than is required to reproduce their labour power - which Marx calls a 'subjective condition' of the existence of surplus-value and profit - but must also fulfil its 'objective condition', namely that 'they also can perform surplus labour: that natural conditions are such that a part of their available labour-time is sufficient to produce and maintain them as producers; that the production of their necessary means of subsistence does not consume their entire labour-time'.150 Other restrictions to this 'natural condition' would e.g. be the natural fertility of the cultivated land (though chemical manipulation has already in Marx's times undermined such 'natural restriction'). Seen this way, it is self-evident that capital can only guarantee its reproduction if the 'objective condition' is fulfilled. However, Uno hyperbolically comments:

The limitation which Marx mentions here due to the use-value of commodities imposes, however, a passive constraint upon the unfolding of the law of value. This limitation does not, as the marginal utility theory might assert, actively form any value. Yet a simple-minded approach to the labour theory of value has often neglected the significance of this passive constraint on the law of value, and over-emphasised the active determination of commodity values by the socially necessary input of

\footnotetext{
149 Uno 1980, p. 69. Sekine quotes from Marx 1965, pp. 635-6. The corresponding passage in Marx 1981, p. 774. Emphasis added.

$150 \quad$ Marx 1981, p. 773.
} 
labour-time alone. Such a one-sided view tends to obstruct a full understanding of the law of value, the peculiarity of which is that it enforces itself only through the motion of prices. ${ }^{151}$

What Uno presents as a use value-based 'constraint' to capitalist self-valorisation is nothing short of a truism: in order to survive, the workers must be able to also work for themselves, and not entirely for the capitalist. If they didn't, there would hardly exist an expenditure of human living labour at all. It is in this context that Marx discusses the relevance of use value. The relevance of use value however in no way infringes the fact that with their wage, the producers buy a part of the total social value product represented in terms of value, not in terms of use value. In his emphasis on labour reproduction, Uno disregards this point. The reproduction of labour-power 'in the private lives' of the workers (eating, drinking, dressing, occupying a habitat and reproductive labour) can only take place on the condition of the monetary form of the means of reproduction, wage as a form of value. ${ }^{152}$ This is all the more strange since Uno has emphasised that social reproduction requires circulation of inputs and outputs in monetary terms, and that the total social surplus results from the exchanges of the products of unpaid labour among the capitalists of the two departments. Therefore, the reproduction of labour power is first and foremost mediated in terms of value, according to which general social reproduction is mediated under capitalist conditions. We will return to this in more detail in discussing Uno's 'Ricardian assumptions' in the next section. For now, let us return to Uno's quote above. In the given quote, Marx argues that ' $[t]$ he social need, i.e. its use value on the social scale, here appears decisive for the quota of total social labour-time that falls to the share of the various particular spheres of production.'.153 As in every other instance where Marx uses the verb 'to appear' or its grammatical correlates, one should be alert. It describes a factual appearance which is often promptly refuted by the succeeding sentence: 'But this is simply the same law that is already exhibited by the individual commodity ... it is a point that bears on the relation between necessary and surplus labour only in as much as an imbalance in this proportion means that

\footnotetext{
151 Uno 1980, p. 69.

152 We have already pointed to Ricardo's failure to articulate the reproduction of labour in terms of the monetary expression of the value of labour power, and its sole articulation in terms of use value - see his presentation in the section 'On Wages', in which the essential part of the labourer's necessities are expressed in 'corn wages'. Ricardo 1969 [1817], pp. $5^{8-}$ 9 .

153 Marx 1981, p. 774. Emphasis added.
} 
the commodity value, and therefore also the surplus-value contained in it, cannot be realized'. ${ }^{154}$ In other words: if a part of the working day was not spent on the reproduction of labour-power, the value of the commodity could not be realised - private reproduction forms the precondition for the realisation of surplus value. Clearly, the realisation of the commodity value is decisive. The realisation of the total value of the commodities however implies that a part of this value is produced to furnish workers' consumption. But before it enters the sphere of private consumption, it exists as value - as being a value product on the market. But this neither serves to undermine the law of value, nor presents a 'modification' of Marx's labour theory of value. In other words, it is difficult to see how the 'use-value aspect of the commodities' limits or 'restricts' the workings of the law. When Marx says: 'Only such-and-such a quantity of this is required in order to satisfy the social need,',155 this is a truism in no way impeding the fact that, first and foremost, the means of consumption enter the market in the form of commodities. However, Uno quotes Marx to support his view that use value restricts (or broadens) social demand, and therefore also the law of value itself: 'Only such-and-such a quantity of this is required in order to satisfy the social need. The limit in this case emerges through the use-value. Under the given conditions of production, society can spend only so much of its total labour-time on one particular kind of product' ${ }^{\prime 26}$ This is quite obvious, and relates to Marx's previous discussion of the eminent role of agricultural production which 'must be sufficient to produce the necessary foodstuffs for the entire society, i.e. also for the non-agricultural workers.'157 Uno's understanding however is led astray, blinded by his insistence on the relevance of use value: the use value aspect of the commodity - which is here understood as supply and demand regulating capitalist production in the last instance - does not only not infringe the law of value, it lacks any bearing on it: if supply does not meet social demand, as e.g. in the case of the overproduction of cotton goods, and the sales price necessarily falls, then obviously too much labourtime (necessary and surplus) had been spent on its production. But this can only be measured quantitatively, i.e. in terms of value. Accordingly, if the sales price falls below the value of a commodity, production in the next cycle will have to take a new form, e.g. lead to the lowering of wages, so that the commodity value can be readjusted. In short, if supply fails to meet demand, the

154 Marx 1981, p. 774. Emphasis added.

155 Marx 1981, pp. 774-5.

$15^{6}$ Marx 1981, p. 775. Emphasis added. Sekine quotes from Marx 1965, pp. 635-6.

157 Marx 1981, p. 773 . 
market price will change and most probably fall. In other words, the 'use value aspect' of the commodity has absolutely no bearing on the working on the law of value, which is always and exclusively determined by quantitative proportions (as e.g. reflected in the new value composition of productive capital). This is why Marx, rather laconically, remarks that "[this] quantitative barrier to the quotas of social labour-time devoted to the various particular spheres of production is simply a further developed expression of the law of value in general; even though necessary labour-time takes on a new meaning here'.158 The demand aspect of the market economy, therefore, does not impose 'a passive constraint on the law of value.'159 But Uno insists that 'a simple-minded approach to the labour theory of value has often neglected the significance of this passive constraint ... and over-emphasised the active determination of commodity values by the socially necessary input of labour-time alone.' ${ }^{160}$ This view is the result of a confusion of the quantitative expressions of the law of value (in prices, e.g.) with the law of value itself, i.e. the fact that the value of commodities is quantitatively determined by the average socially necessary labour time required for their production. ${ }^{161}$ To be sure, towards the end of the presentation of the simple reproduction schemas and the transition to expanded reproduction, in order to confirm the consistency of his own analysis, Marx emphasises that accumulation does not take place at the expense of consumption - simply because, more generally, capital does not produce for demand to begin with:

... we simply note that it was presupposed in our presentation of simple reproduction that the entire surplus-value in departments I and II was spent as revenue. In point of fact, however, one portion of surplus-value is spent as revenue, and another portion transformed into capital. Only with

\footnotetext{
$15^{8}$ Marx 1981, p. 774.

159 Uno 198o, p. 69.

160 Uno 1980, p. 69 .

161 There are obvious similarities of Uno's view with Paul Sweezy's interpretation of the law of value as a 'theory of general equilibrium'. Sweezy: 'What Marx called the "law of value" summarizes those forces at work in a commodity-producing society which regulate a) the exchange ratios among commodities, b) the quantity of each produced, and c) the allocation of the labor force to the various branches of production'. Sweezy 1942, pp. $5^{2-}$ 3. The law of value, as in Uno, is 'essentially a theory of general equilibrium'. Sweezy 1942, p. 53. Notwithstanding the strange assertion of a 'law' as a 'theory', Sweezy, again like Uno, emphasises the 'self-regulation' or, in Uno's term, the 'self-sustenance' (sore jishin ni sonritsu suru mono) of the capitalist market: '... in a commodity-producing society, in spite of the absence of centralized and coordinated decision-making, there is order and not simply chaos'. Sweezy 1942, p. 53. For a critique of Sweezy, see Postone 1993, pp. 44-6.
} 
this precondition does real accumulation take place. But the idea that accumulation is achieved at the expense of consumption - considered in this general way - is an illusion that contradicts the essence of capitalist production, in as much as it assumes that the purpose and driving motive of this is consumption, and not the grabbing of surplus-value and its capitalization, i.e. accumulation. ${ }^{162}$

In a theory of value that relinquishes its fetish-characteristic appearances be it production for use value or equivalent exchange - Marx's intervention is bound to go unnoticed.

In an admittedly polemical intervention against the equilibirium model of the Uno School more broadly, and Sekine in particular, ${ }^{163}$ Michael Lebowitz argues that:

... of course there is no place for class struggle in this Stepford edition of Capital ... Everything has already been determined by supply and demand in a perfectly competitive model. Simply assume a natural rate of population growth and a desired rate of accumulation out of the surplus, and the atomised workers who compete against each other (but do not combine) receive as wages what is necessary to keep everyone more or less happy and the system running. Nothing in 'this liberal utopia, in which the existing resources are optimally allocated for the production of all use values' and where workers 'enjoy a historically feasible standard of living in a state close to full employment' would make a neoclassical economist uneasy - as long as the term 'positive non-wage income' were to be substituted for 'exploitation.'164

\subsubsection{Ricardian Assumptions}

As we have seen before, the reproduction of labour-power as the sine qua non of capitalist reproduction and accumulation, is regarded by Uno solely in terms of use value. In this aspect, he shares a basic assumption with Ricardo and his school (e.g. Ramsay), which can be even traced back to Smith's conceptualisation of capital. Let us take a look at Marx's discussion of the 'misunderstandings

\footnotetext{
162 Marx 1978, 579 .

163 We will return to our discussion of the Uno School and in particular Sekine's equilibrium model in Chapter 5.2.

164 Lebowitz 2005, pp. 321-2. Lebowitz quotes from Sekine's 'Dialectic of Capital'. Sekine 1986, p. 98 .
} 
on Ricardo's part' 165 with regard to the reproduction of labour-power in an early conception of the part on the 'Theories of Surplus Value' in the Grundrisse and briefly also in the $1861-63$ Economic Manuscripts in which Ricardo's repetition of Smith's error is more obvious. ${ }^{166}$ From here we shall see how Uno relies on the same presuppositions as Ricardo - while Uno's view even more fatally misrepresents Marx's critical emphasis of the creation of value as the basis of surplus value. According to Marx, Ricardo still adhered to Smith's notion on the general character of capital, namely that capital is 'command over alien labour', instead of comprehending the nature of capital's exploitative character, not 'in the sense that ... it gives its possessor buying power, but that it is the power to appropriate alien labour without exchange, without equivalent, but with the semblance of exchange.'167 Therefore Ricardo's understanding of the determination of value by labour with regard to wages ('revenue from labour') is limited to the view that a particular quantity of labour can set 'sometimes more and sometimes less living labour into motion. Here, we find no determination of the materialised labour that can set living labour 'in motion' in value terms, but merely in terms of direct use value:

... [Ricardo] regards the product of labour in respect of the worker only as use value - only as the part of the product which he needs to be able to live as a worker. But how it comes about that the worker suddenly only represents use value in exchange, or only draws use value from the exchange, is by no means clear to him ... But why is it, then, that the share of the worker in the value of the product is determined not by the value, but rather by the use value of the product, thus not by the labour time employed in it, but by its quality of maintaining living labour capacity?168

How close indeed Uno's understanding of the 'value of labour' in terms of use value is to Ricardo's assumptions shall be illustrated by this passage from the 1861-3 Economic Manuscripts:

The VALUE or LABOUR is therefore determined by the means of subsistence which, in a given society, are traditionally necessary for the maintenance and reproduction of the labourers. But why? By what law is the

\footnotetext{
165 Marx 1973, p. 551.

166 The subdivision 'Theories of Surplus Value' has been added to the Grundrisse in the 'Analytical Contents List'.

167 Marx 1973, p. 551.

168 Marx 1973, pp. 551-2.
} 
VALUE OF LABOUR determined in this way? Ricardo has in fact no answer, other than that the law OF SUPPLY AND DEMAND reduced the average price of labour to the means of subsistence that are necessary (physically or socially necessary in a given society) for the maintenance of the labourer. He determines value here, in one of the basic propositions of the whole system, by demand and supply - as Say notes with malicious pleasure. ${ }^{169}$

Here, 'in one of the basic propositions of the whole system', Ricardo suddenly deviates from the determination of the 'value of labour' as the (relative) quantity of labour time contained in it. He exempts the determination of wages from the law of value to delegate it to the law of supply and demand (causing much of the schadenfreude of his contemporary Jean-Baptiste Say). ${ }^{170}$ This is compounded by the fact that he repeats Smith's original error with regard to use value being represented in different exchange values:

Adam Smith errs when he concludes from the fact that a definite quantity of labour is EXCHANGEABLE for a definite quantity of use value, that this definite quantity of labour is the measure of value and that it always has the same value, whereas the same quantity of use value can represent very different exchange values. But Ricardo errs twice over; firstly because he does not understand the problem which causes Adam

169 Marx 1989b, p. 36. Marx refers to the following passages: 'Labour, like all other things which are purchased and sold, and which may be increased or diminished [in quantity] has its natural and its market price. The natural price of labour is that price which is necessary to enable the labourers, one with another, to subsist and perpetuate their race, without either increase or diminution. The power of the labourer to support himself, and the family which may be necessary to keep up the number of labourers, does not depend on the quantity of money which he may receive for wages, but on the quantity of food, necessaries, and conveniences required for the support of the labourer and his family. With a rise in the price of food and necessaries, the natural price of labour will rise; with the fall in their price, the natural price of labour will fall'. Ricardo 1969 [1817], p. 52. 'It is not to be understood that the natural price of labour, estimated even in food and necessaries, is absolutely fixed and constant. It varies at different times in the same country, and very materially differs in different countries. It essentially depends on the habits and customs of the people'. Ricardo 1969 [1817], p. 54.

170 The supply-and-demand interpretation of capitalist reproduction is by necessity conceived of in terms of use value, such that consumer demand structures the production of value. Accordingly, Uno remarks that "[the] theory of market value emphasises the impossibility of neglecting the effect of use-value in the determination of the value of the commodity, although the part played by the demand side in this determination must always be considered passive'. Uno 1980, p. 93, footnote 9 . 
Smith's errors; secondly because disregarding the law of value of commodities and taking refuge in the LAW OF SUPPLY AND DEMAND, he himself determines the value of labour, not by the quantity of labour BESTOWED UPON T H E FORCE OF LABOUR, BUT UPON T H E WAGES ALLOTTED T O T H E LABOURER. Thus IN FACT he says: The value of labour is determined by the value of the money which is paid for it! And what determines this? What determines the amount of money that is paid for it? The quantity of use value that a given amount of labour commands or the quantity of labour that a definite quantity of use value commands. And thereby he falls literally into the very inconsistency which he himself condemned in Smith. ${ }^{171}$

In the relation of the product of labour in respect to the worker, the value expression is extinguished and substituted for use value. But this is begging the question, for when the value of labour is determined by the 'necessaries' for workers' consumption, it would be equally necessary to determine the value of the necessaries. In this sense, Brentel remarks:

The determination of wages, a quantity determined by price, by the price of the necessaries is categorially tautological. The concept of 'natural price' in a certain sense is used as a bulwark against this predicament, by attempting to explain the value of labour by a non-value category, i.e. a certain amount of use values necessary for the maintenance of the labourer. With this reference to a certain quantity of use values necessary for the reproduction of the labour capacity however, the problem of the value determination of the labour power commodity is by no means solved, but merely transferred to the value determination of the necessaries. Ricardo however does not relate the value of the necessaries to the socially necessary labour time contained in them, but to [the argumentative level of] relative prices. In this case however, again [as in Smith], the 'value of labour' is determined by the quantity of commodities which it can buy or command. ${ }^{172}$

In other words, the theory of the reproduction of labour power in terms of use value is socially undetermined and hence altogether unspecific to capitalist relations of production. ${ }^{173}$ Ricardo's predicament also holds for Uno:

\footnotetext{
171 Marx 1989b. p. 39.

172 Brentel 1989, p. 77.

173 This model of reproduction is also adopted recently by 'feminist' social reproduction the-
} 
the relation of labour-power to capital is comprehended as being structurally mediated by use value 'in the private life of the workers themselves', ${ }^{174}$ in the 'individual consumption of wage-earners'. ${ }^{175}$ Therefore, the labour-power commodity is the only commodity which 'capital by itself cannot directly produce,', ${ }^{176}$ suspending the law of value in the cycle of private consumption. Hence, like Ricardo, Uno distinguishes the determination of the value of labour-power from the determination of 'commodity values in general'. In the same vein, he insists that the 'reproduction of labour-power forms the individual consumption-process of the workers parallel to, but not integrated in, the production-process of capital ...177 Marx's critique targets Ricardo's neglect to consistently apply the labour theory of value to the category of wages. Because, if he had applied his value theory to what seems to be an exchange of equivalents between capital and labour, Ricardo would have realised that the exchange between capital and labour is essentially based on the exchange of non-equivalents - though, 'as a bourgeois', he could not have been clear about this process. Marx: 'Now, how one gets from value as equivalent determined by labour to the non-equivalent, i.e. which posits surplus-labour through exchange, i.e. how one gets from value to capital, from one aspect to its apparent opposite, this does not interest Ricardo.'178 It was left to Marx to provide an explanation of the exchange between capital and labour as essentially an exchange of non-equivalents appearing in the form of equivalent exchange. The determination of the wage by the labour-time necessary to reproduce the labouring faculties of the labourer in terms of value, i.e. in strict accordance

ories (see e.g. Gonzalez and Neton 2014, Bhattaracharya (ed.) 2017, Mezzadri 2019). In the theoretical framework of this approach, social reproduction is treated solely in terms of use value. It is thus altogether unspecific to capitalism whose defining characteristic is monetary mediation of social reproduction. See our critique of the framework of usevalue-mediated reproduction in Chs. 2 and 5.3. See also Heinrich's critique, which rejects the contention that capital hinges on unpaid reproductive labour: "[With the increasing development of productive powers in the rise of capitalism], the "setting free" of women from household labour and their direct exploitation by capital, makes it possible for capital not only to appropriate a greater mass of surplus value, but a rising rate of surplus value: because the costs of reproduction for one family must be covered by two instead of one labour power, the value of individual labour power decreases'. Heinrich 1999, p. 262. Own translation. Already for Marx, the treatment of the wage form as 'an external and irrelevant formality in capitalist production' allows us to 'readily deduce what an F. Bastiat understands about the nature of capitalist production' (Marx 1976, p. 1006).

174 Uno 1980, p. 52.

175 Uno 1980, p. 51.

176 Uno 1980, p. 52.

177 Uno 1980, pp. 62-3.

178 Marx 1973, p. 56o. 
with the labour theory of value, was of 'decisive importance' to Marx. In the chapter on 'Wages', we therefore find one of his fiercest polemical remarks against the determination of wages as the 'value of labour' in conventional political economy:

We may therefore understand the decisive importance of the transformation of the value or price of labour-power into the form of wages, or into the value and price of labour itself. All the notions of justice held by both the worker and the capitalist, all the mystification of the capitalist mode of production, all capitalism's illusions about freedom, all the apologetic tricks of vulgar economics, have as their basis the form of appearance discussed above, which makes the actual relation invisible, and indeed presents to the eye the precise opposite of that relation. World history has taken a long time to get to the bottom of the mystery of wages; but, despite this, nothing is easier to understand than the necessity, the raison d'être, to this form of appearance. ${ }^{179}$

However, whereas Ricardo, were he consistent, would have had to recognise the factual reality of the exploitation of surplus labour by capital in its confrontation with the living labour of the workers - capital as a 'definite social relationship'180 - Uno is already well aware of this fact. But, again like Ricardo, 'this does not interest' him. Uno's pure theory dispels the problem of appearance and essence in the central category of 'value of labour', and with it, the problem of fetishism. Pure theory is therefore disinterested in enabling a critique of capitalism by bringing the complex of appearance (or capital's self-

\footnotetext{
179 Marx 1976, pp. 680-1.

180 Marx 1989, p. 37. Ricardo was altogether unaware of the concept of the production of absolute surplus value, and only had an (no less confused) understanding of the concept of relative surplus value. Hence, he 'does not comprehend capital as a relation of domination which coerces the workers to work beyond the point that would correspond to the reproduction of their wages'. Brentel 1989, p. 74. While Marx takes the varying length of the working day as the assumption to conceptualise the production of relative surplus value, Ricardo, who only considers the different distribution of the surplus product without its original production, assumes the working day as fixed. 'For him it is a fact, that the value of the product $>$ the value of the WAGES. HOW this fact arises, remains unclear. The total working day is greater than that part of the working day which is required for the production of the WAGES. Why? That does not emerge. The magnitude of the total working day is therefore wrongly assumed to be fixed, and directly entails wrong conclusions. The increase or decrease in surplus value can therefore be explained only from the growing or diminishing productivity of social labour which produces the NECESSARIES. That is to say, only relative surplus value is understood'. Marx 1989, pp. 41-2.
} 
representation) and essence (the way capital really operates) to the fore. It merely reiterates its mode of 'operation' in a positivistic form, addressing capital's appearance alone. The 'law of value' thus degenerates into a theory of general social reproduction in which the conversion of value into production prices (i.e. the allocation of labour to the different spheres of production to result in a general rate of profit) 'confirms the law of value by ensuring the feasibility of social reproduction'. ${ }^{181}$ For Uno, the reproduction of labour power, solely based on use value, can only be viewed from the level of real circulation in which commodities are sold and purchased as products of capital. While in Uno's discussion of general social reproduction in the abstract, wages are expressed in monetary (value) terms, in considering the real movement of capitalist production where production and market price fluctuations take place, use value determines value by imposing a 'passive constraint' upon the law of value in the reproduction of labour power. In the real process therefore, active demand (and supply) determine the law of value in the last instance. Use value, expressed in demand-and-supply relations, triumphs over value:

In Capital, vol. III, part ii, chapter 10, Marx tries to develop a theory of market value. His explanation, however, remains unsatisfactory because he does not articulate the significance of price fluctuations in the market in adjusting demand and supply. This point, I believe, is of some methodological importance. Marx's general neglect of the demand-and-supply analysis impairs his theory of value-forms at the outset of Capital already, placing the rest of his economic doctrine on rather precarious ground. ${ }^{182}$

He therefore shares another of Ricardo's strategical moves, namely 'taking refuge in the law of supply and demand'. ${ }^{183}$ Here is why Uno introduces the 'passive constraint' of use value - the fact that capital 'cannot directly produce' the labour power faculty of the workers - into his study of pure capitalism to begin with. Precisely by being located in the sphere of the use values of commodities, the law of value can finally be proven: namely by the governance of society's total annual reproductive powers, guaranteeing an equilibrium of supply and demand. The law of value, so to speak, takes a detour through the mode of individual consumption expressed in use value in order to finally prove the 'automatic power of self-regulation' of capitalist social production. This is the bearing the reproduction of labour power 'in the private lives' of

181 Uno 1980, p. 93, footnote 6.

182 Uno 1980, p. 93, footnote 8.

183 Marx 1989, p. 39. 
the workers has on establishing the 'law'. Hence, Uno remarks that ' $t \mathrm{t}] \mathrm{he}$ theory of market value emphasises the impossibility of neglecting the effect of use-value in the determination of the value of the commodity, although the part played by the demand side in this determination must always be considered passive.'184 In other words, 'because of the inherent incompleteness that inevitably-recurrently emerges whenever capital's logic attempts to display itself as a perfect circle, this logic should not work, yet it works perfectly well in capitalist society'.185

Neither Ricardo nor Uno take theoretical account of the fact that it is the transformation of a law of exchange into a law of appropriation, the appropriation of surplus without an equivalent, that characterises capitalist production as a whole. In both conceptualisations, the character of capital that constantly confronts and contradicts living labour as a material force is neglected. But while in Ricardo, this misrecognition is explained by the disconcertedness to clarify the exchange of non-equivalents on the basis of equivalent commodity exchange (because of the 'bourgeois' impediments of his own enterprise), Uno is well aware of Marx's own solution to the riddle. Still, the strategic importance of the Marxian insight is disavowed in Uno's conceptualisation of general capitalist reproduction, and the law of accumulation declared compatible with the law of general equilibrium. This result necessitates a brief examination of Uno's basic marginalist assumptions.

\subsubsection{Marginalist Assumptions}

Let us recall Uno's conceptualisation of use value, putting a restraint or 'limitation' to the operations of the law of value when applied to actually existing market relations. i.e. market values and market prices:

This limitation does not, as the marginal utility theory might assert, actively form any value. Yet a simple-minded approach to the labour theory of value has often neglected the significance of this passive constraint on the law of value, and over-emphasised the active determination of commodity values by the socially necessary input of labour-time alone. Such a one-sided view tends to obstruct a full understanding of the law of value, the peculiarity of which is that it enforces itself only through the motion of prices. ${ }^{186}$

184 Uno 1980, p. 93, footnote 9.

185 Walker 2016, p. 17o. For a discussion of Walker's intervention, see Chapter 5.3.

186 Uno 1980, p. 69. 
As we could see from the above discussion, Uno attempts to reconcile the use value-based demand and supply determination of prices with the law of value that 'rests on the workers-versus-capitalists relation in the production-process of capital; for without this relation the law of value cannot operate on a social and global basis.' ${ }^{187}$ In other words, by systematically diverging from market values 'is a commodity-economy enabled objectively and efficiently to allocate the social labour to all the branches of industry as social need requires'.188 Market value guarantees the equilibrium between supply and demand, so that supply can naturally adjust to demand. The market value of the commodity, as will be explained in the next chapter, suspends the law of value in the sense that it adjusts to the commodities produced in the branch of production in which the average conditions of production prevail. Yet, if the real process of adjustment between demand and supply via market values systematically diverges from the real value of a commodity, i.e. the form constantly digresses from its content, then how can we say that the 'law of value' enforces itself upon capitalist production 'as if it were a natural law'?189

Indeed, in order to prove the 'general norm of economic life common to all societies', as which Uno, at odds with Marx, understands the law of value, Uno subsumes the theory of value to an understanding in which marginalist assumptions dominate. We have demonstrated this in Chapter 3. Here, Uno's rejection of the 'Third Thing', abstract human labour as the objective basis for the value form of money, i.e., Uno's rejection of an objective theory of value, is eminent. As seen before, in simple exchange, Uno draws on the economic rationality of the commodity owners and their 'want' (yokubō) of the use value of the commodity in the equivalent form to explain the generation of money as a means to facilitate exchange on a general social scale. Only now, however, at the level of the discussion of total social reproduction, can we see how intrinsically this fundamentally marginalist view of society also informs Uno's theory of general social distribution.

The 'marginalist revolution' primarily consisted in shifting the problematic in classical political economy - namely the question of the rational distribution of social wealth, as reflected in the 'Trinity Formula' - to the question of how the rationality of the capitalist system can be established on the basis of allocative efficiency. Consequently, marginalism restricted economics to a field of technology, purified classical political economy of the 'political', and discarded all

187 Uno 1980, p. 84.

188 Uno 1980, pp. 84-5.

189 Uno 1980, p. 84. This question, giving rise to the 'transformation problem', will be discussed in the next chapter. 
assumptions of the specifically social, historical and particularly class character of the capitalist mode of production. By its primary claim to present a 'rigorous theory of price determination,' 190 in which the scientific character of its theory would prove itself, untouched by 'imperfect conditions' in the real world, marginalism even endeavoured to radically separate the realm of economics from the study of society or 'sociology'. Needless to say, this claim does not imply that the marginalist view of price, of resources, of technical innovation and its hypothesis of 'perfect competition' is free from implicit assumptions about society, and especially about its individuals. The most immediate expression of marginalism's understanding of the individual is expressed in the rationality of exchange, which becomes the foundation for the basic theory of price in marginalist economics. In marginalism, the view of economics as a science is based on the presuppositions of a radical methodological individualism in which the agents of exchange act according to the optimisation of their own position expressed in the maximisation of utility, which in this framework is tantamount to the principle of rationality. While being different in the detailed elaborations of their respective works, the main thinkers of the marginalist school, William Stanley Jevons (1835-82) in England, Léon Walras (1834-1910) in Switzerland (Lausanne), and Carl Menger in Vienna (1840-1921) ${ }^{191}$ - independently of one another, but almost simultaneously - developed the theory that prices emerge on the basis of individual exchanges between owners of goods. Insofar, they reject the views of Ricardo and Smith that an 'independent measure of value' must exist on whose basis a theory of price can be established. As the classical economists insist, a utility theory of price would involve the paradox that the 'highest prices are paid for the most worthless goods, such as diamonds, while the most useful goods, such as air, are free.'192 The marginalist school tries to solve this paradox by saying that the price does not correspond to the 'total utility' of the good, but to the utility of the last unit of the good that was acquired. If an individual is in possession of a great quantity of

190 Clarke 1991, p. 143.

191 Other important marginalists include Alfred Marshall (1842-1924), Johann G.K. Wicksell (1851-1926), Friedrich von Wieser (1851-1926), and Philip Henry Wicksteed (1844-1927), who also has written a critical review of Capital (see Wicksteed 1884). Their main works included Marshall's Principles of Economics (189o), Wicksell's Interest and Prices (1898), Wieser's Der natürliche Werth (1889) (the English translation, Natural Value, appeared in 1893), and Wicksteed's Common Sense of Political Economy including a Study of the Human Basis of Economic Law (1910). We are following Clarke's and Heinrich's careful presentation of the main contentions of marginalist theory. See Clarke 1991 and Heinrich 1999.

192 Clarke 1991, p. 147 . 
a particular good, then the 'utility of the marginal good tended to diminish'.193 The price level and the value of goods therefore depend on the condition of scarcity, so that the value rises in proportion to its increasing scarcity: the price of diamonds is high not because of the relatively high amount of labour input, but because the marginal utility ${ }^{194}$ is high as a consequence of the diamonds' scarcity. However, scarcity is not an 'objective' qualifier for the exchange relation: in the marginalist view, all goods are subject to relative scarcity in the face of total demand, in smaller or greater intensity. For the individual, then, the rational optimisation of its position in exchange is the main incentive for exchange. In exchange, the goal for the individual consists in increasing the sum of utilities at his/her disposal, so that individual behaviour is necessarily directed at increasing the sum total of his or her use values. From this point of view, a situation in direct barter, value is subject to individual evaluation: the 'individual will choose to exchange goods until the relative marginal utilities of the goods possessed at the end of the transaction correspond to the exchange relations in which they stand'.195 In marginalism therefore, it is assumed that in the process of exchange the individuals compensate for the 'loss of utility' in the alienated good with the 'gain of utility' in the good received. The individuals only accept kinds of exchange pairs in which they have a prospect of gain or, at the least, no prospect of loss. This is only the case if the marginal utility of the quantity of alienated goods is smaller or equal to the marginal utility of the goods received. Exchange, finally, only takes place for precisely those goods in which, for all the agents of exchange, the marginal utility of the quantities of goods is the same. ${ }^{196}$ Characteristically however, marginalism applies this view to a more general conception of economic input and output: it is at the root of its understanding of economy that its essential results can be extended from the case of the isolated individual making subjective private decisions ... to the case of an exchange economy considered as a whole.'197 Therefore, the process of price determination on the market with many more agents of exchange results from the aggregation of the functions of supply and demand based on individual utility estimations. If 'individual demand and

\footnotetext{
193 Clarke 1991, p. 147.

194 The term of 'marginal utility' (Grenznutzen) was originally coined by Wieser (Wieser 1884), but converges with Jevons's term 'final degree of utility', Menger's 'Value of the least important partial quantity', as well as Walras's 'rareté.' See Heinrich 1999, p. 66 footnote 10. For a detailed discussion of the theories of the three founding fathers of marginalism, see Lehmann 1977 and Blaug 1985.

195 Clarke 1991, p. 147.

196 See Heinrich 1999, p. 67.

197 Clarke 1991, p. 151.
} 
supply functions are aggregated, total demand and supply functions can be specified. It can be shown that under appropriate assumptions ... the interaction of demand and supply will give rise to a unique set of stable equilibrium prices that clear all markets by equalising supply and demand. These prices are those that correspond to the free and rational choices of all the individual members of society seeking to achieve their own optimal solution in conditions of scarcity'.198 This view is further supplemented by the emphasis on the unique role of households in a national economy and private consumption. In the national circulation of goods, households supply the services of productive factors to firms and purchase from firms the goods that are produced with those productive services. Not production, but consumption stands at the heart of economic circulation. Economic rationality however requires the existence of a free market 'as a means by which individual evaluations of utility can be related to one another, and the freedom and security of property as the basis of free exchange ... The marginalist analysis therefore also purports to establish the social rationality of a society based on competitive exchange by establishing that the prices reached, and the consequent allocation of resources, are in some sense optimal.' ${ }^{199}$ This converges with Uno's view discussed above that market values always guarantee a stable equilibrium between supply and consumer demand in accordance with the 'law of value' as the commodity-economic form of the 'behavioural norms of economic life shared by ... all human societies.' ${ }^{200}$ In particular, a closer look at the basic approach of Carl Menger's theory in relation to Uno's seems to be rewarding, though, for reasons of space, the following will only allow us to discuss a few fundamental traits in Menger's approach that suggests its compatibility or similarity with Uno's views on the methodology of economic science. Like Uno, Menger in his main work Principles of Economics (Die Grundsätze der Volkswirtschaft, 1871) proposes a 'pure economic theory' as a methodological template for economic science in which the real processes of economic activity are suspended. That means that rather than viewing the actual economy as object, the object of that theory is theory itself. It takes 'idealised basic assumptions' as the template to review whether they conform or contradict mathematically sound operations. ${ }^{201}$ For Menger, as for other marginalists, pure theory is able to prove its superiority over other economic theories in the determination of prices. However, the object of pure

\footnotetext{
198 Clarke 1991, p. 148.

199 Clarke 1991, p. 15 o.

$200 \quad$ Uno 1980, p. 20.

201 For a critique of the micro-foundational economic assumptions of marginalism, and especially the circular character of its model building, see Kade 1962 and Ritsert 1988.
} 
theory is not concerned with the determination of real prices, but with 'their determination in an ideal world of perfect knowledge, perfect foresight, perfect competition and pure rationality.'202 Similarly to Uno, pure theory abstracts from the real world as a methodological strategy, so that 'it is against this ideal world that the real world, and proposed reforms in the real world, are to be measured.203 In the narrower sense, the theory of value which he formulated in exact contradistinction to Marx's, was central to Menger's intervention. ${ }^{204}$ Menger saw in the marginalist approach a fundamental explanation of the precise mechanism by which money and price - 'organically created' social institutions ${ }^{205}$ - 'emerge from the pursuit of individual self-interest and come to express the collective wisdom of society.' ${ }^{206}$ Menger therefore, like Uno, and unlike Marx, insisted on the need to relate social institutions such as money and exchange back to their 'origins in individual action in order to establish their foundations in the natural and spontaneously evolved needs and aspirations of individuals. ${ }^{207}$ Pure theory for Menger depends on the extent to which general economic processes of exchange can be derived from individual 'utility maximising' behaviour. ${ }^{208}$ Especially the founding concept of value is here understood as a neutral, and hence, natural and aboriginal relation between the individual and the object/good/commodity of his/her want, expressed in a subjective judgment, and therefore nothing that has objective existence - an assuption laying bare its Baileyan roots. For Menger, value is hence defined as

nothing inherent in goods, no property of them, nor an independent thing existing by itself. It is a judgment economizing men make about the importance of the goods at their disposal for the maintenance of their lives and well-being. Hence value does not exist outside the consciousness of men. It is, therefore, also quite erroneous to call a good that has

202 Clarke 1991, p. 145. See also Shaikh 2016, pp. 340-46.

203 Clarke 1991, p. 145.

204 It is precisely the 'refutation' of Marxism that motivates Menger's publisher, the Ludwig van Mises-Institute, to write about The Principles of Economics: 'It was this book that kicked-off the Marginalist Revolution, which corrected theoretical errors of the old classical school. These errors concerned value theory, and they had sown enough confusion to make the dangerous ideology of Marxism seem more plausible than it really was'. https:// mises.org/library/principles-economics (last consulted September 3oth, 2019).

205 Menger 1963, p. 177.

206 Clarke 1991, p. 146.

207 Clarke 1991, p. $15^{2}$.

208 For Uno, this is expressed in the task of the pure theory of political economy to study 'a historical process made up of the purposive activities of men (ningen no kōdō ni yoru rekishiteki katei wo kagakuteki ni kaimei shiyō to suru mono)'. Uno 1980, p. xxiii. 
value to economizing individuals a 'value', or for economists to speak of 'values' as of independent real things, and to objectify value in this way. For the entities that exist objectively are always only particular things or quantities of things, and their value is something fundamentally different from the things themselves; it is a judgment made by economizing individuals about the importance their command of the things has for the maintenance of their lives and well-being. Objectification of the value of goods, which is entirely subjective in nature, has nevertheless contributed very greatly to confusion about the basic principles of our science. ${ }^{209}$

This view is entirely consistent with Uno's emphasis on the role of the commodity owner in the simple value expression, namely that the judgment of the want for the coat, i.e. the subjective and unilateral initiative of linen owner, makes the coat a value expression of the linen. Money, therefore, arises 'spontaneously' from the mediation of the interest of the different commodity owners in direct barter, as a result of the mediation of different kinds of wants. This is substantially the marginalist view of money. ${ }^{210}$ Furthermore, especially Menger's view on value is profoundly informed by the methodological individualism of 'need' or 'want': 'Our previous explanation ... demonstrates that man, with his needs and his command of the means to satisfy them, is himself the point at which human economic life both begins and ends. ${ }^{211}$ The inductive method of going back to the 'satisfaction of needs and desires' as the founding principle of economic science's categories also informs Uno's focus on use value to explain the productive and reproductive faculties of capitalism's 'self-sustenance'. As is clear from the previous, Uno does neither assume the general condition of scarcity, nor does he share the marginalist view of the 'factors of production' theory of the three sources of revenue. ${ }^{212}$ However, at the most general level

209 Menger 1950, p. 1201.

210 'The inconveniences of direct barter originally led some enterprising individual to attempt to achieve exchange through the mediation of a third good that was highly exchangeable. As others imitated the innovator that good came to take on the character of money. Thus money too had a rational origin as a technical instrument invented by individuals in order to perfect the process of utility-maximisation'. Clarke 1991, p. 153.

211 Menger 1950, p. 108.

212 According to marginalist theory, classical political economy was too occupied with labourtime or costs of production in resolving the annual national income (wages, rent and profit) which should instead be seen as accruing to factors of production labour, land and means of production. See Clarke 1991, p. 149. Seen this way, marginalism has only reformulated Smith's and Ricardo's problem, while being inflicted with the same vicious circle. 
of marginalist theory, Uno shares the basic assumptions of 1. the constitutive role of exchange in determining value, 2. the importance of the evaluation of the individuals engaged in the process of exchange, based on subjective want and the rejection of a concept of objectively constituted value (i.e. socially necessary labour time), 3. money as 'purchasing power', 4. the reproduction of individual 'utility maximising' behaviour at the level of general social exchange (methodological individualism), from which follows, 4. that the aggregate functions of supply and demand give rise to equilibrium (market) prices directed at 'satisfying social demand' (Uno), 5. the shift from the producer and production (as in classical theories) to the consumer and consumption (households/the 'private consumption of workers'), and last but not least, 5. the ignorance of the specific property relations giving rise to the appearance of equivalent exchange while being essentially a law of appropriation of alien unpaid labour, in short: the ignorance of the socially and historically specific laws of capitalist appropriation, expressed in Uno's view of reproduction being 'common to all societies', including the specifically commodity-economic forms. ${ }^{213}$ In the next chapter we will see how Uno's understanding of the transformation of values into prices of production (the 'Transformation Problem') further severs social production's ties to labour values. On the theoretical level, we will therefore witness how Uno further severs his ties to Marx's intervention - and with it, discards capitalist society as a problem.

\subsection{Surplus Value and Profit: The 'Transformation Problem' in Uno's Perspective}

As mentioned above, Uno's developed equilibrium theory of value contains a self-contradictory moment - his claim of the indispensability of the law of value' as the regulatory force of total social reproduction ${ }^{214}$ and his simultaneous substitution of the law of value for an emphasis on the principle of supply and demand that he sees insufficiently developed in Marx. ${ }^{215}$ To reconcile the contradiction, Uno adjusts the 'law' of value to his marginalist notion of price, so that in the last instance, the reproduction of labour power in terms of use

213 Uno 1980, p. 84. For a good overview of the circular motives of the 'theory of general equilibrium', see Heinrich 1999, pp. 68-78.

214 Though even this claim is tautological, as shown above.

215 'Marx's general neglect of the demand-and-supply analysis impairs his theory of valueforms at the outset of Capital already, placing the rest of his economic doctrine on a rather precarious ground'. Uno 1980, p. 93. 
value - the muri or 'nihil of reason' of capital - regulates the total social value product by demand, so that the aggregate values do not determine prices, but prices, to the contrary, determine values. In his discussion of the equalisation of profit rates, Uno accordingly parts with his idea discussed above, namely that "[each individual capital] must obey the regulation of the law of value, the global consequence of which is to realise the norm of reproduction common to all societies' leading to the 'automatic power of self-regulation inherent in capitalist commodity economy', as presented in Uno's view of the reproduction schemes. In the equalisation of profit rates, it is no longer the law of value that 'governs' exchange, and therefore, the prices of production, but vice versa: "The determination of values presupposes the adjustment of supply according to the social demand, and the mechanism of this adjustment actually develops only when commodities are supplied as the products of capital.'216 The heuristic value of the 'law of value' for Uno's interpretation of a 'capitalist commodity-economy' in the total social reproduction process consequently becomes as dubious as Uno's appropriation of the concept of abstract labour for his theory of value and money: it is Uno's own interpretation that renders the concepts - both of 'abstract labour', as well as the 'law of value' - redundant as heuristically rich concepts with significant explanatory power. In an ultimate argumentative move, his interpretation of the 'transformation' of commodity values to prices of production severs the ties to the significance of socially necessary labour time once and for all. In the following, we will demonstrate the devastating consequences of this move for a coherent theorisation of the 'law of value' as a methodological and theoretical object. To do so, we find it useful to contrast Uno's view with Marx's incentive to thematise the inherent relationship between values and prices (of production, etc.) to point to a fundamental problem of classical political economy, especially Ricardo. The following presentation however merely serves to introduce the matter, in order to make sense of Uno's perspective. It will be shown that the problem of the value-pricetransformation, in accordance with the pervasive method of Marx's critique in Capital, must be seen against the background of the problem of fetishism. Only an understanding that sees the transformation problem as a qualitative problem of the fetish-characteristics of the bourgeois relations of production can fully grasp the extent to which Marx's own theorisation surpasses the quantitative solutions to the problem Marx himself (and some of his successors) has offered - even beyond Marx's own objective. Though Marx, by his own fetishismcritical method, first and foremost opened up the terrain of potentially viewing

216 Uno 198o, p. 93. 
the equalisation of profit rates this way, he fatally failed to recognise this qualitative dimension of the problem posed by his own method of inquiry. Instead, he chose to solve the problem quantitatively, underestimating the heuristic power of this own approach. This will form a part of the following discussion, though by no means can we, in the context of this volume, hope to exhaustively address the methodological and theoretical problems associated with this lacuna. The full analysis would have to be conducted in a theoretical forum or publication solely engaged with Marx's solution to the transformation problem. In this context, we can only hope to give hints at what we think are promising insights emphasising the coherence of the fetish-critical method throughout the categorial development of all three volumes of Capital.

It will therefore be necessary, first, to present the value-price relation and Marx's solution to it, as he himself saw it in the context of the Critique of Political Economy, namely as a critique of Ricardo's solution. However, the quantitative solution Marx offers in Chapters 9 and 10 of Capital Volume III, as a whole bulk of research literature since Eugen Böhm-Bawerk's first critique (1896) attempted to demonstrate, has proven to be veritably problematic, if not faulty. Therefore, when we speak of the 'transformation problem' in the context of economic theory today, we usually address a problem within Marx's, and not Ricardo's, theory. In this context, it will be necessary to address, if for reasons of space - impossible to exhaustively comment on, Fred Moseley's 'macro-monetary' intervention that more 'radically' applies the quantitative solution to 'Marx's dilemma' offered by the so-called New Interpretation (NI) in the early 1980s. Both Moseley and the NI offer a valuable quantitative heuristic, the 'value of money' or, in a later dictum, the 'monetary expression of labour time' (MELT) to demonstrate the 'retainment' of 'the proportionality of profit and unpaid labor time in the face of any deviations of prices from labour values,'217 that is, the validity of the labour theory of value in the face of prices diverging from labour values. While we strongly agree with the offered solutions, we also believe that both Moseley and the proponents of the $\mathrm{NI}^{218}$ offer an interpretation to a problem whose significance Marx himself was clearly not aware of. Our objective will therefore be to elucidate what conditions of the problem Marx was not aware of, and locate it in a lack of insight into the scope and explanatory power of his own method. Our investigation therefore differs from the 'macro-monetary' quantitative solution in stressing the qual-

\footnotetext{
217 Foley 1982, p. 37.

218 To which we will return in the context of non-equilibrium theory and Sekine's critique in Chapter 5.2.
} 
itative significance of the transformation procedure for understanding the problem of fetishism. The succeeding discussion of Uno's view will point us to the basic misrecognition in the perception of the relation between value and price. By disregarding Marx's fetish-critical method, Uno wilfully ignores the wider problem-setting of the 'transformation', namely as being coherently embedded in the method of criticising the increasingly fetish-characteristic value form of price. In the concluding section, we will formulate an attempt to shift the view of the formation of a general profit rate and of prices of production away from the technical-mathematical field to the, as we believe, more fundamental epistemological problematisation of the cleft between our cognition of 'social processes' in their own presentation (Darstellung) and in their real, essential movement.

\subsubsection{Marx's 'Solution' to Ricardo's Transformation Problem}

Marx's attempt to explain the transformation of aggregate values to prices of production was motivated by (as Marx saw it) Ricardo's inability to explain prices on the basis of his own theory of value. For Marx, the contradiction in Ricardo regarding labour values and prices of production arose from the methodological conflation of surplus value and profit in Ricardo's notion of profit. Thus, for Marx, the 'contradiction' between the two must be solved by transforming it into an 'illusion which arises from the development of the thing itself'.219 In other words, as discussed above, because Ricardo was inconsequential in applying his own theory of value to the exchange between capital and labour, he could not develop a theory of surplus value, and hence, a theory of exploitation. Only after the concept of surplus value has been developed purely ('rein entwickelt') could the equalisation of profit rates and the theory of prices of production be demonstrated in order to investigate their relationship. ${ }^{220}$

219 Marx 1989a, p. 266. This is the concise way in which 'Hegel Helped Marx To Overturn Ricardo's Theory of Profit'. See Murray 2014.

220 As to how Ricardo's conflation of surplus value and profit informs the basis of Ricardo's inability to distinguish value from cost price, Marx comments: 'It has already been shown in some detail, that the laws of surplus value - or rather of the rate of surplus value (assuming the working day as given) do not so directly and simply coincide with, nor are they applicable to, the laws of profit, as Ricardo supposes. It has been shown that he wrongly identifies surplus value with profit and that these are only identical in so far as the total capital consists of variable capital or is laid out directly in wages; and that therefore what Ricardo deals with under the name of 'profit' is in fact surplus value. Only in this case can the total product simply be resolved into wages and surplus value. Ricardo evidently shares Smith's view, that the total value of the annual product resolves itself into revenues. Hence also his confusion of value with cost price'. Marx 1989b, p. 6o. 
Ricardo however presupposed a general rate of profit throughout the Principles (1817), although the concept of wages is systematically developed only in Chapter 5 and that of profit in Chapter 6. Yet, he wasn't clear on how the concept of surplus value, profit and a general rate of profit - or, indeed, cost price - could emerge from his own concept of value at all. It was precisely this problem - how to get from the determination of value by relative labour quantities to prices which precisely do not reflect labour values - that constituted Ricardo's contradiction and the specifically Ricardian transformation problem. Marx comments:

IN FACT the only thing which he proves ... is that the prices of the commodities, in so far as they are determined by the general rate of profit, are entirely different from their values. And he arrives at this difference by postulating the rate of profit to be LAW. One can see that though Ricardo is accused of being too abstract, one would be justified in accusing him of the opposite: lack of the power of abstraction, inability, when dealing with the values of commodities, to forget profits, a FACT which confronts him as a result of competition.

Because Ricardo, instead of deriving the difference between cost prices and values from the determination of value itself, admits that 'values' themselves (here it would have been appropriate to define the concept of 'ABSOLUTE' OR 'REAL VALUE' OR 'VALUE' as such) are determined by influences that are independent of labour time and that the law of value is sporadically invalidated by these influences, this was used by his opponents, such as Malthus, in order to attack his whole theory of values. ${ }^{221}$

Of course, for Marx, the relationship between values and prices was one of structural dependency: the empirical, apparent fact of the equalisation of rates of profit is directly based on the non-empirical, essentially constitutive nexus of value production. Marx was therefore determined to show that the former must and can be explained on the basis of the latter.

Ricardo's inconsequential application of the labour theory of value played a significant role for Marx's own motivation to quantitatively deduce the value form of price from the value they contain. First of all, Marx saw a transformation problem in Ricardo and tried to solve it by showing that the equalisation of profit rates and the formation of prices of production fundamentally rested on the value quantities produced in the different branches of production. ${ }^{22}$

$221 \quad$ Marx 1989a, p. 416.

222 Here is not the place to discuss Ricardo's own version of the solution in detail. Suffice it 
Here is where the stakes of his critique of Ricardo lay - namely in criticising Ricardo's inability to conceptually differentiate constant and variable capital, which forms the basis to understanding how production prices systematically diverging from labour values could emerge at all. Instead, Ricardo relies on the difference between the proportions of fixed and circulating capital invested, and hence, the difference between circulation and production time. Ricardo's modifications to his own 'embodied labour' theory of value can be found in Section IV of Chapter 1 of the Principles:

It appears, then, that the division of capital into different proportions of fixed and circulating capital, employed in different trades, introduces a considerable modification to the rule, which is of universal application when labour is almost exclusively employed in production; namely, that commodities never vary in value unless a greater or less quantity of labour be bestowed on their production, it being shown in this section that, without any variation in the quantity of labour, the rise of its value merely will occasion a fall in the exchangeable value of those goods in the production of which fixed capital is employed; the larger the amount of fixed capital, the greater will be the fall. ${ }^{223}$

For Marx however, only the conceptual differentiation between variable capital as living and value-creating labour, and constant capital as dead labour and not Ricardo's 'secondary' determination of value in the difference between proportions of fixed and circulating capital - can clarify how the 'modification' from values to production prices arises at all. Helmut Brentel summarises Marx's rejection of Ricardo's understanding of the problem in terms of fixed and circulating capital in the following way:

to say that Ricardo tried to 'modify' his value theory by assuming that a change in wages influences the cost prices (not the values), and hence the rate of profit of the respective capitals, so that e.g. wage rises have a different effect on the rates of profit of commodities produced with different relations between direct and indirect labour. If the exchange relation between two commodities does not change after a rise in wages (in both lines of production), then both commodities are no longer produced with the same rate of profit, i.e. yield different cost prices. From this, Ricardo followed that the relative values of the commodities are subject to change even if the labour quantities do not change, namely in the case of different amounts of direct/indirect labour, or in the case of wage changes. See Marx 1989a, pp. 417-20. Also see Heinrich 1988.

223 Ricardo 1969 [1817], pp. 23-4. 
... the relation between constant and variable capital was originally responsible for the production of sectorally different surplusvalues, which are redistributed with the emergence of a general rate of profit. By virtue of the addition of a uniform rate of profit onto the sum of the total capital advanced, they [the surplus values] are differently realised than they are produced [werden sie anders realisiert als produziert.] The differentiation between constant and variable capital shows the production and the distribution of surplus value and therefore clarifies the category of profit. Ricardo on the other hand was exclusively concerned with what has to be conceived as the subordinate 'different forms arising out of the process of the circulation of capital, that is, fixed and circulating capital, capital which is fixed to a greater or lesser degree (i.e., fixed capital of varying durability) and unequal velocity of circulation, or rates of turnover of capital'.224

Marx's incentive to find a solution to the transformation problem was motivated by demonstrating the fundamental dependency of prices of production on labour values. At the same time, it would hinge on this demonstration whether the labour theory of value had any validity with regard to the 'Process of Capitalist Production as a Whole', as presented in the manuscripts for Volume III of Capital - after all, the level of analysis in which capital's perfected self-mystification and fetishisation 'at the surface' would be revealed and rationally countered. Marx's allegedly 'failed' attempt to successfully demonstrate the equivalence of prices of production to labour values, i.e. Marx's failed transformation procedure, caused the fierce rejection of Marx's labour theory of value received in the history of its reception. This is, however, also what motivates us to defend, not the quantitative solution with regard to Marx's transformation procedure (which we believe Moseley has sufficiently shown), but the methodological quality of Marx's investigation into capital's mystification process, a quality that, as we will show, was not always appreciated by its own author.

To first explain the problems in Marx's solution, it is therefore useful to present Marx's answer to Ricardo's problem in more detail, which we will do in the following.

224 Brentel 1989, p. 93. The quote is from Volume II of the Theories of Surplus Value where Marx discusses Ricardo's theory of cost price. Marx 1989a, p. 401. 
As mentioned above, in Volumes I and II, and also at the beginning of Volume III, of Capital - i.e. at the level of the essential conceptual and nonempirical analysis of the capitalist production and circulation process - Marx assumes that commodities are exchanged at their values, i.e. at 'prices' that directly correspond to the socially necessary labour time for their production ('value-prices'). In accordance with the method of the presentation, this was hypothetical. Only after developing the concept of profit and cost price in Chapters 1-3 of the manuscripts to Volume III - an already fetishised, transformed concept of surplus value and value - could he show that, at the surface of capitalist production under the condition of different branches of production and competition, real prices necessarily diverge from values. On the assumption that the rate of surplus value is the same for all individual branches, and the organic composition of capital (the rate between $\mathrm{c}$ and $\mathrm{v}$ ) is different, the exchange of commodities over the different productive sectors would result in completely different profit rates. Evidently however, profit rates tend to equalise - trivially because capital 'seeks for as much surplus value as possible', so that, were it not the case, capital would collectively assemble in the sphere of production with the highest rate of profit. Competition therefore manages to equalise the rate of profit. Since the equalisation of profit rates in a national economy is an empirical fact, the prices that guarantee this equalisation must necessarily diverge from the values of the commodities. Marx calls these prices production prices: they are neither market prices (which are constantly subject to change), nor merely 'sales prices'. Prices of production, rather, denote a new value form in the course of the methodological presentation. They result from the competition between the sum of all branches of production to guarantee an average rate of profit to be gained from every individual capital in social production as a whole. In contrast, the market production price, or 'market value' in Marx's terminology, expresses competition within individual branches in one line of production. In other words, prices of production 'arise when the average of the different rates of profit is drawn from the different spheres of production, and this average is added to the cost prices of the different spheres of production ... ${ }^{225}$ The price of production $p$, for Marx, consists of the cost price $k$ (the costs of the productive capital for the capitalist) plus the average profit (a surcharge to the cost price in proportion to the capital employed), so that $\mathrm{p}=\mathrm{k}$ $+\mathrm{kp}$, or $\mathrm{p}=\mathrm{k}\left(1+\mathrm{p}^{\prime}\right) \cdot{ }^{226}$ On the basis of this formula, Marx attempts to prove

225 Marx 1981, p. 257.

226 Marx 1981, p. 265: 'The formula that the price of production of a commodity $=k+p$, cost price plus profit, can now be stated more exactly; since $p=k p^{\prime}$ (where $p^{\prime}$ is the general rate 
how the level of the average rate of profit and accordingly, the prices of production, can be established on the basis of the value quantities produced in all spheres of production. In the style of an axiom, i.e. without further deducing this claim, Marx hypothesises that the average rate of profit derived from the system of production prices is identical to the average rate of profit in each production sphere in terms of value. In other words, the average rate of profit must be identical with the ratio of surplus value to the complete social capital invested in the totality of social production ('value rate of profit'), during a particular time span. If we consider five different types of capital with different value compositions, then, in Marx's example, we arrive at the following schema:

\begin{tabular}{|c|c|c|c|c|c|c|c|}
\hline Capitals $^{\mathrm{a}}$ & $\begin{array}{c}\text { Rate of } \\
\text { surplus } \\
\text { value }\end{array}$ & $\begin{array}{c}\text { Surplus } \\
\text { value } \\
\text { (s:v) }\end{array}$ & $\begin{array}{c}\text { Rate of } \\
\text { profit } \\
(\mathrm{s}: \mathrm{c}+\mathrm{v})\end{array}$ & Used up c & $\begin{array}{c}\text { Value of } \\
\text { commodities } \\
\text { (used } \\
\text { up c+v+m) }\end{array}$ & $\begin{array}{l}\text { Cost price } \\
\text { (used up } \\
\text { c+v) }\end{array}$ & \\
\hline I. $8 \mathrm{oc}+2 \mathrm{OV}$ & $100 \%$ & 20 & $20 \%$ & $5^{\circ}$ & 90 & 70 & \\
\hline II. $7 \mathrm{OC}+3 \mathrm{OV}$ & $100 \%$ & 30 & $30 \%$ & $5^{1}$ & 111 & 81 & \\
\hline III. 6 oc $+40 \mathrm{OV}$ & $100 \%$ & 40 & $40 \%$ & $5^{1}$ & 131 & 91 & \\
\hline IV. $85^{c+1} 5^{V}$ & $100 \%$ & 15 & $15 \%$ & 40 & 70 & 55 & \\
\hline V. $95^{c+5 v}$ & $100 \%$ & 5 & $5 \%$ & 10 & 20 & 15 & \\
\hline $390 c+110 v$ & & 110 & $110 \%$ & & & & Total \\
\hline $78 c+22 v$ & & 22 & $22 \%$ & & & & Average \\
\hline
\end{tabular}

a See Marx 1981, p. 256. Heinrich formalises this schema as $r=\Sigma s_{i} / \Sigma\left(c_{i}+v_{i}\right)$, if $s_{i}, c_{i}$ and $v_{i}$ denote surplus value, constant and variable capital for the i-th sphere of production, and $\Sigma$ the sum of all $i$, and $r$ the average rate of profit. See Heinrich 1999, p. 269.

If we now treat the different single capitals $\mathrm{I}-\mathrm{V}$ as a single total capital and distribute the surplus value of 22 or the rate of profit of $22 \%$ evenly among the capitals $\mathrm{I}-\mathrm{V}$, we would arrive at the following prices of production of the commodities:

of profit), the price of production $=k+k p^{\prime}$. If $k=300$ and $p^{\prime}=15 \%$, the price of production $k+k p^{\prime}=300+30015 / 100=345^{\prime}$ 


\begin{tabular}{lcccccc}
\hline Capitals $^{\mathrm{a}}$ & $\begin{array}{c}\text { Surplus } \\
\text { value }\end{array}$ & $\begin{array}{c}\text { Value of } \\
\text { commod- } \\
\text { ities }\end{array}$ & $\begin{array}{c}\text { Cost price } \\
\text { of com- } \\
\text { modities }\end{array}$ & $\begin{array}{c}\text { Price of commodities } \\
\text { (cost price + average } \\
\text { rate of profit) }\end{array}$ & $\begin{array}{c}\text { Rate of } \\
\text { profit }\end{array}$ & $\begin{array}{c}\text { Divergence } \\
\text { of price } \\
\text { from value }\end{array}$ \\
\hline I. 8 OCc+2OV & 20 & 90 & 70 & 92 & $22 \%$ & +2 \\
II. 7 OC+3OV & 30 & 111 & 81 & 103 & $22 \%$ & -8 \\
III. 6oc+4OV & 40 & 131 & 91 & 113 & $22 \%$ & -18 \\
IV. $85 \mathrm{C}+15 \mathrm{~V}$ & 15 & 70 & 55 & 77 & $22 \%$ & +7 \\
V. 95C $+5 \mathrm{~V}$ & 5 & 20 & 15 & 37 & $22 \%$ & +17 \\
\hline
\end{tabular}

a See Marx 1981, p. 256. Heinrich accordingly formalises this schema for the price of production of the i-th commodity (i.e. the product of the i-th sphere) as $\mathrm{p}_{\mathrm{i}}=\left(\mathrm{c}_{\mathrm{i}}+\mathrm{v}_{\mathrm{i}}\right)\left(1+\Sigma \mathrm{s}_{\mathrm{i}} / \Sigma\left(\mathrm{c}_{\mathrm{i}}+\mathrm{v}_{\mathrm{i}}\right)\right)$. See Heinrich 1999, p. 269 .

b This should more correctly read as 'Prices of production of commodities'. However, at this point Marx has not yet introduced the concept of the price of production.

As we can see from the last column in the latter table, the divergence of price from value in the individual capitals, when considered as one single total capital, balances itself out. Therefore, a divergence of price from value, taken in production as a whole, does not take place:

Taken together, commodities are sold at $2+7+17=26$ above their value, and $8+18=26$ below their value, so that the divergences of price from value indicated above cancel each other out when surplus-value is distributed evenly, i.e. through adding the average rate of profit of 22 on the capital advance of 100 to the respective cost prices of commodities I-V ... And it is only because they are sold at these prices that the rates of profit for capitals $\mathrm{I}-\mathrm{V}$ are equal at 22 per cent, irrespective of their different organic compositions ...227

With this table and method of transformation, Marx thinks he has finally proven his initial claim, namely that the production price system must rest on the basis of the value system by necessity, keeping his theory of value intact. He has thus provided a solution to the value-price-transformation on the basis of his own labour theory of value, fulfilling the two axioms following from this claim, namely that $\mathrm{I}$. the sum of profits must be equal to the sum of surplus value 'which this capital produces in a given period of circulation', ${ }^{228}$ and II. 'the sum of prices of production for the commodities produced in society as a whole

227 Marx 1981, p. 257.

228 Marx 1981, p. 141. 
... is equal to the sum of their values'.229 Marx therefore believes he has shown that these particular rates of profit in each sphere of production are $\mathrm{s} / \mathrm{C}$ and 'to be developed from the value of the commodity as shown in the first Part of this volume', in which he demonstrates the notion of profit as being a derived, a 'mystified' form of the real and fundamental relation between abstract labour and capital in the notion of surplus value. ${ }^{230}$ The congruity between prices of production and values in the production of commodities in society as a whole is of decisive importance for Marx, since

[i]n the absence of such a development, the general rate of profit (and hence also the production prices of the commodity) remains a meaningless and irrational conception. Thus the production price of a commodity equals its cost price plus the percentage profit added to it in accordance with the general rate of profit, its cost price plus the average profit. ${ }^{231}$

Two important consequences must be drawn from this: one is unproblematic and merely serves to specify Marx's understanding of surplus value production on the surface of totally developed, competitive capitalism: profit accrues to the individual capitals only in proportion to the total social capital advanced. The allocation of surplus value or profit in the perspective of total capital consequently rests on a redistribution of surplus value to the individual branches of production. In other words, as soon as competition is considered, even a favourable (low) organic composition of capital can only realise a portion of the profit it would realise under different conditions. Single capitalists therefore never realise the 'full' surplus value produced in their own branch of production, but only a fragment of the surplus product generated in social production as a whole, by the whole working class. This also means that the notion of 'individual value' is, strictly speaking, self-contradictory, even if Marx uses this

229 Marx 1981, p. 259.

230 'In surplus-value, the relationship between capital and labour is laid bare. In the relationship between capital and profit, i.e. between capital and surplus-value as it appears on the one hand as an excess over the cost price of the commodity realised in the circulation process and on the other hand as an excess determined more precisely by its relationship to total capital, capital appears as a relationship to itself, a relationship in which it is distinguished, as an original sum of value, from another new value that it posits. It appears to consciousness as if capital creates this new value in the course of its movement through the production and circulation processes. But how this happens is now mystified, and appears to derive from hidden qualities that are inherent in capital itself'. Marx 1981, p. 139. We will return to this quote below to analyse its importance for the fetishism-critical approach to the 'transformation problem'.

231 Marx 1981, p. 257. 
term to differentiate it from the market value of a commodity (more on this in the next section).

The other consequence is of a more technical nature, and also more devastating for Marx's own quantitative solution to the value-price-transformation: while the first axiom is merely a hypothesis which is impossible to prove empirically (which must not mean it is wrong), the second axiom contains a logical flaw and is, therefore, untenable: it assumes that the capitalists can buy their productive capital and, likewise, the workers their means of subsumption, at their respective values. However, in fully developed capitalism in conditions of competition, this is impossible: productive capital as well as means of consumption are traded at definitive prices. Therefore, the standard reproach against Marx's calculation method is that he had allegedly 'forgotten' or 'failed to transform the inputs' 232 in his calculation of cost prices (see table 2, column 5). This is of course a problematic formulation, because the transformation of the inputs already requires the existence of prices of production on whose basis cost prices could afterwards be accounted for. In other words, the problem is not one of Marx's 'forgetfulness'. The standard reproach also misses that Marx was well aware of the problem;; ${ }^{233}$ but he fatally underestimated its significance for the quantitative solution, as Heinrich emphasises. ${ }^{234}$ The problem rather consists in the circular logic of Marx's quantitative solution to the value-price calculus: cost prices cannot be accounted for in separation and before the prices of production, because cost prices themselves must be calculated on the basis of production prices. Seen this way, cost prices (and prices of production) must be accounted for simultaneously. But, as Heinrich has poin-

232 We use Moseley's formulation. See Moseley 2016, p. XII.

233 A divergence of prices of production from values can 'arise out of the following reasons' for Marx: '( 2 ) because the price of production of a commodity that diverges in this way from its value enters as an element into the cost price of other commodities, which means that a divergence from the value of the means of production consumed in a commodity may already be contained in the cost price, quite apart from the divergence that may arise from the difference between average profit and surplus-value'. Marx 2015 [1864-5], p. 318.

234 'While Marx himself pointed to this "mistake", he completely underestimated its significance'. Heinrich 1999, p. 270. Instead, Marx casually comments: 'As the price of production of a commodity can diverge from its value, so the cost price of a commodity, in which the price of production of other commodities is involved, can also stand above or below the portion of its total value that is formed by the value of the means of production going into it. It is necessary to bear in mind this modified significance of the cost price, and therefore to bear in mind too that if the cost price of a commodity is equated with the value of the means of production used up in producing it, it is always possible to go wrong. Our present investigation does not require us to go into further detail on this point'. Marx 1981, p. 265. Emphasis added. 
ted out, then we cannot assume that 'the general rate of profit of the production price system coincides with the average rate of profit of the value system, ${ }^{235}$ hence, not only the second, but also the first axiom becomes untenable. This predicament however seems to concern the tenability of the labour theory of value as a whole.

\subsubsection{Uno's Perspective}

It is unnecessary at this point to refer to the vast amount of both Marxist and non-Marxist literature either discussing solutions to the transformation problem, or taking it to present fundamental objections to Marx's conception of value and sometimes even to declare the theoretical 'bankruptcy' of Marx's teaching as such (e.g. Samuelson, Steedman, Morishima, analytical Marxists such as Elster, Roemer, Cohen). ${ }^{236}$ The general reproach concerning the socalled 'transformation problem' is that Marx made an error in hypothesising the two axioms of 'aggregate equalities' simultaneously, namely I. That the total profit is equal to the total surplus value (rate of profit = 'value rate of profit') and II, that the total price of production is equal to the total value (that the divergence of price from value in the total economy $=0$ ). ${ }^{237}$ Since both cannot coincide to form a coherent theory of values and price in the real capitalist economy, the theory of production in Volume I (and Volume II) of Capital is declared redundant. We are therefore stuck with a theory of the apparent movements of price without being able to coherently, i.e. logically ground the

235 Heinrich 1999, p. 270.

236 For Steedman, Marx's labour theory of value is redundant, because inputs/outputs can be specified according to physical quantities: '... value magnitudes are, at best, redundant in the determination of the rate of profit (and prices of production) ... [because] the physical quantities of commodities and of labour specifying the methods of production, together with the physical quantities of commodities specifying the given real wage rate, suffice to determine the rate of profit'. Steedman 1978, p. 202. For similar critiques from a neoRicardian standpoint, see Seton 1957, Samuelson 1971, Morishima 1973, Elster 1985, Roemer 1981, Cohen 1981, though Sweezy was arguably the first to revive the Bortkiewicz model (see Sweezy 1942, pp. 115-25). See also, from a different viewpoint, Napoleoni's (Napoleoni 1974) and A. Brewer's (Brewer 1995) similar argument. For a nearly exhaustive overview of the debates on the 'transformation problem' until 1988 and a critique of these views, see Heinrich 1988. For a recent survey and critical discussion on different solutions to the problem since 1988, starting with the Tssi interpretation (Kliman and McGlone 1988), see Moseley 2016, pp. 286-36o. Moseley especially targets the understanding of inputs/outputs as 'physical quantities', emphasising the role of money capital, i.e. the fact that a given sum of money, not a given sum of physical inputs, stands at the beginning of the valorisation process. For further critiques of the 'physical' view, see Foley 1997.

237 This view was held by Bortkiewicz (Bortkiewicz 1906-7), and later reformulated by the neo-Ricardians. See Moseley 2016, p. XII. 
prices of commodities in labour values. Or so it seems. ${ }^{238}$ What is more interesting is the claim that no such thing as a transformation 'problem' exists in Marx's presentation, because the prices of production have always-already been 'transformed' from the beginning of the presentation. It is Fred Moseley who came forward with this view in recent years, especially in his seminal Money and Totality (2016). In the book, he presents a strong argument based on both algebraic calculus and textual evidence to show that there 'is' no transformation problem in Marx, if only we take Marx's method seriously. Moseley's work, based on research over more than two decades, is therefore arguably the most well-crafted argument in 'defence' of the coherence of Marx's presentation throughout the three volumes of Capital, and hence, on the labour theory of value. Unfortunately, his 'macro-monetary' approach cannot be discussed in detail in the context of this study. Suffice it to say that Moseley shows through a careful philological analysis of Marx's text that the three volumes of Capital are commonly based on the form of a monetary expression of labour time - a monetary expression of value in 'value-price' - so that Marx assumes a given $\mathrm{M}$ as the value form of prices of production from the beginning of the analysis. Moseley therefore rejects the 'standard interpretations' (Bortkiewicz, Sweezy, the Sraffian interpretations of Morishima and Steedman) on the basis of their interpretation of physical (non-monetary) input-output schemas. The given $\mathrm{M}$ at the start of the circuit of money capital M-C ... P ... C'-M' is the only known variable here, so that, unlike a simultaneous determination of the 'inputs' and 'outputs', a sequential determination of the variables is required. Therefore, what is at stake at the level of Volume III of Capital is not the 'proof' that labour values must be 'transformed' into prices of production, but, rather, that on the level of the theory of distribution of Capital Volume III, profit, interest and rent as concrete monetary forms of value are based on the appropriation of surplus labour by the capitalist class as a whole, which is based on the theory of production of Volume I. In other words, for Moseley, there are no two versions of cost price, one based on values (i.e. the sum of the actual constant capital and vari-

238 The debates surrounding Böhm-Bawerk's 'refutation' - arguably one of the earliest and most influential attempts to refute the Marx's value theory on the basis of the 'contradiction' between Volume I and III of Capital (Böhm-Bawerk 1949 [1896], p. 30) were also known to Uno. Especially Hilferding's reply, but also Tugan-Baranowski's intervention of 1905, Theoretical Foundations of Marxism (Leipzig: Duncker \& Humboldt) was known to Uno, while he did not comment on the more recent debates (Sraffa and the neo-Ricardians). Uno was arguably influenced by Böhm-Bawerk, although he presented a (precarious) critique of the chapter on Marx in Böhm-Bawerk's 'Capital and Interest' ('Kapital und Kapitalzins', 1884) in the introduction to Value Theory. To our knowledge, Uno also did not further engage with Bortkiewicz's 'new method' of calculation. 
able capital advanced), and one based on prices of production. There is only one cost price, based on values. Therefore, as Moseley states, 'according to this interpretation and contrary to the traditional interpretation, Marx did not fail to transform the inputs because the inputs (the cost prices) are not supposed to be transformed ... but are instead supposed to be the same magnitude $(\mathrm{K})$ in the determination of both values and the prices of production.' ${ }^{239}$ Moseley argues this by a close comparison between Marx's original manuscript and Engels' edition of Volume III. ${ }^{240}$ But the contention that 'the inputs are not supposed to be transformed', so that there is 'nothing to transform' is odd in the face of Marx's own elaborated efforts at a transformation procedure from labour values to prices of production in Chapter 9 of Capital Volume III. The NI and Moseley's 'macromonetary' approach therefore much rather provided solutions to a problem that Marx was clearly not aware of. Similarly to recent - sometimes more, sometimes less justified - attempts to declare a 'non-existence' of a transformation problem in Marx, ${ }^{241}$ Uno does not acknowledge the existence of a problem. Of course, this view is also the result of a particular kind of interpretation. In the following, I will first provide an account of Uno's understanding (in the Principles) of both the relation between labour values and prices of production, and second, the concept of market values - a prominent term for Uno - in its relation to supply and demand. While in the Principles, however, Uno merely stresses the regulatory influence of the supply-and-demand factor to generate an equilibrium of the profit rate, without directly referring to Marx (except accusing Marx of underestimating this factor, as shown above), in Part IV of his earlier Methodology of 1962, we find a more fundamental critique of Marx. Uno

239 Marx 2015 [1864-5], pp. 15-16.

240 It is therefore possible to view Moseley's intervention as a more 'thoroughgoing' variant of the quantitative solution offered by the so-called New Interpretation, which we have pointed to earlier (see Dumenil 1980, Foley 1982, and Lipietz 1982), and which we will return to in detail in Chapter 5.3. As Foley says, the money wage multiplied by the value of money implies 'that the value of labour power is equal in magnitude to the wage share in aggregate value added'. Foley 1982, p. 42. In other words, the value of labour power is already transformed in terms of price expressing its exact value, i.e. the 'fraction of the working day that is paid labour'. Moseley 2016, p. 256. Moseley's interpretation is more radical, because, in contrast to e.g. Foley's explanation, not only the value of labour, i.e. the wage (v), is 'already transformed', but also constant capital (c). For criticisms of Moseley's interpretation, see Kliman's 13-part series (as of 17 January 2017), 'All Value-Form, no Labour Substance' in Marxist-Humanist Initiative (https://www.marxisthumanistinitiative.org/uncategorized/ all-value-form-no-value-substance-comm ents-on-moseleys-new-book-part-1.html, last access 15 Aug. 2019), and Freeman 2019.

241 '... the "transformation problem" ... simply does not exist'. Milios 2009, p. 269. If it does not 'exist' however, what is it that Milios addresses? 
here criticises Marx's conceptualisation of market values and market prices that Uno regards as the result of a more fundamental flaw in Marx's basic theory of the form and substance of value.

Part III of the Principles, the 'Doctrine of Distribution' (bunpairon), immediately begins with Uno's theorisation of the formation of the general profit rate and, accordingly, the transformation of values into production prices. First, he presents the view that 'in a purely capitalist society in which unrestricted competition prevails among capitals, ${ }^{242}$ all commodities must be traded at definite prices. Capital must use labour-power and the means of production in the most efficient way, so that a 'normal standard' can be reached, in which all capitals tend to equalise their profits. Uno concludes that '[o]nly with these general presuppositions can it be made apparent that capital possesses the faculty of allocating itself to the various spheres of production so as to supply all the products that society demands,, ${ }^{243}$ again propagating his dominant view of capitalism as a basic demand-satisfying and use value-oriented economic formation. Yet, on what factors in Uno's view does the formation of a general rate of profit, on the condition of competition between all industries or branches of production, depend? For him, it depends on the three factors of (1) the rate of surplus value, (2) the (organic) composition of capital, and (3) the turnover-time of capital, consisting of both the production-period and the circulation-period. The turnover-time of capital, however, is abbreviated by the intermediary function of commercial capital, so that commercial capital also indirectly participates in the formation of a general profit rate. To discuss the problem at hand, we need not go back to the discussion of commercial capital as it is sufficiently explained in Chapter 4.1. As for (2), understanding the dependence of the general rate of profit on the rate of surplus value (the ratio between necessary labour time and surplus labour time) is relatively unproblematic. Uno merely stresses the relevance of the production of relative surplus value with the technical progress of the means of production and the historical tendency to equalise the rate of surplus value across all branches of the industry with technical progress: 'Inequalities that in practice remain in the rate of surplus value over different capitalist activities must be attributed to certain particular conditions requiring in each case separate explanations.'. ${ }^{244}$ Consequently, it is in (1) that the formation of a general rate of profit confronts its most fundamental problem against the background of the 'law of value'. For

242 Uno 1980, p. 76.

243 Uno 198o, p. 76.

244 Uno 198o, p. 78. 
technical reasons, differences in the composition of capital between the productive branches must be allowed for. In contrast to the rate of surplus value, they do not tend to equalise with technical progress, for some branches of production, i.e. large-scale operations as e.g. heavy metal industries, require a higher composition of capital than small-scale industries (e.g. the hospitality industry), yielding a smaller rate of profit, accounted for on the basis of surplus values. As a consequence, the different industries would yield completely different profit rates. To therefore guarantee the even distribution of profits over the different branches of production, it 'becomes unavoidable that the price of the products produced with a higher composition of capital rises above its value and the price of those produced with a lower capital composition falls below its value. ${ }^{245}$ For Uno, hence, 'the prices that equalise profits that accrue to all capital investments of the same value are, therefore, equilibrium prices. ${ }^{246}$ Like Marx, Uno terms these prices production-prices (or prices of production). As a consequence, and by introducing the notion of market pricethat however arises not from inter-sectional, but intra-sectional competition between commodity suppliers - Uno sees little controversial potential in the transformation of values into production-prices:

In other words, production-prices which consist of the cost-price plus the average profit earned by the total of invested or advanced capital regulate the social supply of capital's products in place of values ( $k a c h i$ ni kawatte); for market prices that fluctuate in response to the forces of demand and supply gravitate towards production-prices rather than to values. This conversion of values into production-prices, however, does not imply any change in the labour-time required to produce each commodity. This technical requirement is taken for granted when capital, guided by production-prices, determines the quantity of each commodity that it will supply socially. In other words, here again capital makes a commodityeconomic detour. Since it cannot know directly what quantity of each commodity ought to be socially supplied, the production of which requires a definite quantity of labour-time, capital relies on the market form of production-prices to allocate itself and labour with it to the various spheres of industrial production, thereby ensuring that the socially necessary labour-time is spent for the production of each individual product. ${ }^{247}$

245 Uno 1980, p. 78.

246 Uno 1980, pp. 78-9.

247 Uno 1980, p. 79. A translation closer to the original of the sentences in italic would be: 
According to Uno, 'in reality' capital does not produce according to the labour time socially necessary in terms of value, but orients itself towards production prices. Production prices guarantee that socially necessary labour time is automatically readjusted to the quantities 'needed' in every branch of production as soon as they form the centre of gravity around which market prices, determined by supply and demand, gravitate. But then there is no reason to believe that labour values form the theoretical basis on which to determine the 'price fluctuations' on the market. With this theory of production price, the assumption of values becomes redundant.

Additionally, conscious planning of the economy is no longer a problem, since, by the automatism of the prices of production, capital 'relies on the market form of production-prices' to guarantee the supply of products in proportions of socially necessary labour time. But socially necessary labour time is then no longer determined by the 'value rate of profit', it is determined by the 'profit rate of profit' and thus is altogether detached from the ratio of the surplus product to paid labour. Moreover, it is based on the ratio of the surplus product to both constant and variable capital (the cost price for the capitalist), or the rate of profit. Böhm-Bawerk's most trivial, however central accusation, namely that Marx had not moved beyond Smith, Ricardo and the Physiocrats in his new determination of price, here certainly holds for Uno's interpretation. ${ }^{248}$ It must be noted that Marx even admits that the price of production is the same of the understanding of price in the classics: the point for Marx however is that 'none of these people explained the difference between price of production and value. ${ }^{249}$ As a matter-of-fact, with the elimination of labour values and the 'value rate of profit', Uno eliminates the transformation problem tout court. He substantiates the argument of an automatic readjustment of labour values to prices of production which form the centre of gravity for market prices in each industrial sector by saying that " $[\mathrm{s}]$ ince the products of capital are now traded at prices gravitating towards production-prices which consist of the cost-price plus an average profit (on total invested capital), the movement

'Presupposing this, in order to determine the amount of social production of these commodities, it is necessary for capital to make this detour'. Uno 1964, pp. 147-8.

248 'That price of a commodity which is equal to its cost price plus its share of the yearly average profit of the capital employed (not merely that consumed) in its production (regard being had to the quickness or slowness of turnover) is its price of production. This is in fact identical with Adam Smith's natural price, Ricardo's price of production, and with the prix nécessaire of the physiocrats. And the actual exchange relation of the separate commodities is no longer determined by their values but by their prices of production; or as Marx likes to put it "the values change into prices of production"'. Böhm-Bawerk 1949 [1896], p. 24. 
of prices can no longer be said to be directly governed by the law of value.'250 For Uno, consequently, prices of production that guarantee an equal share in the aggregate profit for all branches of production necessarily diverge from values, and only this divergence establishes the law of value at all. Paradoxically therefore, for Uno, the law of value only holds when it does not hold. At the same time, by disavowing the primordial determination of unpaid labour as the part of the working day in which the labourer produces the surplus, which in turn becomes the primordial form of profit, for Uno, the characteristic of the law of value' consists in a law of social reproduction based on the satisfaction of social demand in a general equilibrium:

... the law of value that governs a commodity-economy does not secure the solid mechanism of its operation, nor the full scope of its application, unless commodities are produced by capital, i.e. unless values are already transformed into production prices. Only by the formation of the rate of profit is it possible objectively to determine the equilibrium quantities of the various use-values that are socially demanded and that technically require a certain labour-time for their production..$^{251}$

Here we can return to the inherently Baileyan assumptions in Uno's value theory: like Uno long after him, Bailey already conceived of money as the sole 'external' measure of commodities. According to Bailey, money need not be the 'absolute' measure of value, and can hence be variable, and by virtue of being variable, evenly and uniformly measure the values of all other commodities. In other words, Bailey can ignore Ricardo's transformation problem and describe the formation of value as a system of exchange of simple relative values. This also means that 'value', as soon as the real process of the formation of a general rate of profit is concerned, is nothing but a relative relation of exchange in a system of quantities. ${ }^{252}$ Hence, for both Bailey and Uno, the concept of production price simply substitutes the concept of value, as soon as the 'total process' of capitalist production and the formation of the general rate of profit is concerned. Both become 'fetish worshippers' of the value form of price. But how, if

\footnotetext{
$250 \quad$ Uno 1980, p. 79.

251 Uno 1980, p. 81. Here we can also see how for Uno the reproduction of total social capital discussed in the previous chapter smoothly adjusts to the value-price-transformation: 'In fact, capital realises the equilibrium state of reproduction in which it forms and augments values only when commodities are exchanged at production-prices since the state of equilibrium implies and depends on a general rate of profit'. Ibid.
}

252 See Brentel 1989, p. 111. 
everything is to the best in the best of all possible worlds, can this interpretation not impede Marx's theory of value as a theory of exploitation of living human labour that is its central critical insight? How does Marx, with Uno's interpretation, in fact move beyond the classical understanding? Uno does not seem to have an answer. Still, he insists that 'this fact [the systematic divergence of the cost price (hence, the production price) from values] does not in any way alter the basic worker-versus-capitalists relation according to which workers devote the necessary labour-time for the production of their own livelihood and the surplus labour-time for the formation of the capitalists' income. ${ }^{253}$ The plausibility of this assertion is however suspended by Uno's own interpretation in which the fundamental dependency of the price system on the value system can no longer be reconstructed. In the following, we will investigate a little further the importance of market values for Uno's 'solution' to the transformation problem. We will show that Uno, in contrast to Marx, ascribes a constitutive role to supply and demand for the formation of market values, relying on a basic assumption of neoclassical economic theory.

\subsubsection{Supply and Demand, Market Value and Market Prices}

The role of market prices and market values (i.e. 'market production-prices') in Marx's further elaboration in Chapter 10 of Volume III of Capital concerns competition within a branch of production of the same type of commodity. Marx discusses these terms against the background of the function of supply and demand, especially its heuristic value in determining prices. Market value for both Marx and Uno is defined as the average value of all the commodities produced in the same branch of production, yet it can also be the individual value of the commodity produced under average conditions of production. But, as Marx points out, the supply of the quantity of a certain type of commodity does not simply 'satisfy demand', it satisfies demand on a particular socialscale. As a rule of thumb, demand and supply regulate the market price or rather, the deviation of the market price from market value, while on the other hand, the market value 'regulates the relationship between demand and supply, or the centre around which fluctuations of demand and supply make the market price oscillate.'254 However it is crucial to see that for Marx, in contrast to Uno, this contention is made on the presupposition that the law of value regulates the prices of production. ${ }^{255}$ Hence, for Marx, demand and supply have no heur-

\footnotetext{
253 Uno 1980, p. 8 o.

254 Marx 1981, p. 282.

255 Marx 1981, p. 281.
} 
istic value for the explanation of the relations under which commodities are exchanged as the products of capital. This point is crucial for Marx:

Here again we can see how absolutely nothing can be explained by the relationship of demand and supply, before explaining the basis on which this relationship functions. ${ }^{256}$

The fluctuations of supply and demand accommodate to market values. Because of this, we might even imagine the case that the constant divergence of supply and demand from value forms a new market value (= the average taken from the different market prices) 'since the departures from these values balance each other as pluses and minuses, when their average is taken.'.257 But demand and supply merely constitute deviations, accidental fluctuations, and cannot explain the dynamic of social reproduction. Marx even goes one step further to prove the tautological character of an explanation that attempts to establish the value form of market value - we shall not forget that market value, like price of production, is a value form - on an equilibrium of supply and demand, i.e. the satisfaction of social needs. In Chapter 10 of Volume III of Capital, Marx carefully analyses, first, the role of supply, and second, the role of demand. Let us first consider supply. The view of supply as a particular sum of commodities, existing in use value to satisfy human needs, fails to recognise that these use values are available on the market in a given scale. ${ }^{258}$ However, according to Marx, there is no intrinsic relation between the quantity of the commodities available on the market and the market value of these articles. The relation merely indicates that on a given basis of labour productivity in the sphere of production in question, the production of a particular quantity of this article requires a particular quantity of social labour time, even though this proportion may be completely different from one sphere of production to another and has no intrinsic connection with the usefulness of the article or the particular character of its use value. ${ }^{259}$

The quantity in which a certain commodity is produced therefore bears no relation to the social usefulness of the article, i.e. the degree in which it satisfies social demand. Accordingly, to say that products are available on the market is not to say that they 'satisfy a demand'. They only satisfy the demand of the solvent participants on the market, people that pay for the products with money. Since production in capitalism is based on the social division of

\footnotetext{
256 Marx 1918, p. 282.

257 Marx 1981, p. 291.

258 Sea Marx 1981, p. 287.

259 Marx 1981, p. 288.
} 
labour, therefore, the part of 'society' (rather, that section of workers) that expends its labour-time on the production of particular commodities 'must receive an equivalent in social labour represented in those articles that satisfy its needs.' ${ }^{260}$ From this, it follows by no means that the extent of the supply of particular quantities of products on the market is directly related to the extent to which they are socially demanded: it only follows that a part of the labour time invested in the production of particular articles buys back a part of the quantity of certain other products available on the market. The relation between the proportion that the production of a certain article assumes in total social labour time and the 'proportion in which the society demands satisfaction of the need appeased by that particular article ${ }^{261}$ is not a necessary, but merely an accidental one. In other words, the market value of a particular commodity depends on factors completely unrelated to the quantity (supply) in which this commodity is available on the market. The same goes for demand. Demand, needless to say, is a social fact without which a part of the reproduction of the annual aggregate product would be impossible. This demand accrues to both capitalists and workers, as we have seen in 4.2., with the crucial difference that the demand of the capitalists is a demand for productive consumption, the purpose of which is the appropriation of surplus value, value without an equivalent. Generally, it seems that, on the one hand,

... there is a certain quantitatively defined social need on the demand side, which requires for its fulfilment a definite quantity of an article on the market. In fact, however, the quantitative determination of this need is completely elastic and fluctuating. Its fixed character is mere illusion. If means of subsistence were cheaper or money wages higher, the workers would buy more of them, and a greater 'social need' for these kinds of commodities would appear, not to mention those paupers etc. whose 'demand' is still below the narrowest limits of their physical need. If cotton, on the other hand, became cheaper, the capitalists' demand for cotton would grow, more excess capital would be put into the cotton industry, and so on. ${ }^{262}$

But the capitalist's need for cotton 'is modified fundamentally by the fact that all it really clothes is his need to make profit'.263 Of course, this does not mean that supply and demand have no bearing on the real prices, i.e. the market prices,

\footnotetext{
26o Marx 1981, p. 288.

261 Marx 1981, p. 288.

262 Marx 1981, p. 29 o.

263 Marx 1981, p. 29.
} 
under which commodities are traded. If supply exceeds demand, commodities must be sold for less than the market value, if demand exceeds supply, commodities are sold above their market value, in this way reflecting deviations from the market value, and with it, the market price. ${ }^{264}$ But from this logic it does not follow that an 'equilibrium' of supply and demand 'determines' market value. Market value itself - the sum of $\mathrm{v}$ and $\mathrm{c}$ plus the average profit, a surcharge to the cost price in proportion to the capital employed - is altogether independent of the coincidence or the 'equilibrium' of supply and demand. To the contrary: market value determines the relationship of demand and supply to begin with. Hence, the fundamental problem in the determination of price by the supply-and-demand-function, argued by marginalism and, in 'value-theoretically modified' fashion also by Uno, is its lack of explanatory power contained in the tautological character of what it is supposed to prove:

Demand and supply coincide if they stand in such a relationship that the mass of commodities produced by a certain branch of production can be sold at its market value, neither above it nor below. This is the first thing we are told. The second is that when commodities can be sold at their market value, demand and supply coincide. If demand and supply coincide, they cease to have any effect, and it is for this very reason that commodities are sold at their market value ... If demand and supply cancel each other out, they cease to explain anything, have no effect on market value and leave us completely in the dark as to why this market value is expressed in precisely such a sum of money and no other. The real inner laws of capitalist production clearly cannot be explained in terms of the interaction of demand and supply ... since these laws are realized in their pure form only when demand and supply cease to operate, i.e. when they coincide. ${ }^{265}$

However, under certain conditions, demand can regulate the market value of a commodity in relation to the conditions of its production. Here is a point in which Marx's argument seems to suggest an alternative to the pure value

264 With the important addition that ' $\mathrm{m}]$ arket prices that diverge from market values balance out on average to become market values, since the departures from these values balance each other as pluses or minuses, when their average is taken. And this average figure is by no means of merely theoretical significance. It is, rather, practically important for capital whose investment is calculated over the fluctuation and compensations of a more less fixed period of time'. Marx 1981, p. 291. Yet, this does nothing to change the fact that market values determine market prices. For Marx's elaboration, see Marx 1981, pp. 291-7.

265 Marx 1981, pp. 290-1. 
determination of market value (i.e. a portion of socially necessary labour time required to produce a commodity under average conditions, providing a proportional share of the individual capital's profit). Marx thus seems to end up with two determinations of market value, one regulated by value, one regulated by demand and supply. At this point, we also find Uno's more elaborate and direct criticism of Marx's explanation of market value in the Methodology. Let us first turn to Marx's, seemingly counterfactual explanation of market value. First, he introduces the term by assuming average market conditions, with the quantity or the mass of the commodities provided as a given. Here, he investigates the influence of quantities of commodities produced under different conditions (favourable and unfavourable) on the deviations of market price from market value in three different cases. In the first case (case I), the market value is equal to the sum of its individual values. Here, the quantity of commodities produced under good conditions and those produced under worse conditions in this same line of production is relatively small, while the greater bulk of commodities is produced under average conditions. The relatively small quantities of extreme conditions of production then correspond to the greater mass of average conditions of production and balance each other out: capitals producing at the worst extreme of the spectrum have to sell their commodities below their individual value, while those producing at the best extreme sell their commodities above it ('normal' case). In this case, the market value of the mass of commodities 'is determined by the value of the great middling mass'. ${ }^{266}$ In case II, the part of the sum which is produced under relatively unfavourable conditions forms a more significant quantity than in case I, so that the individual amounts of commodities produced at the two extremes fail to balance each other out. Accordingly, it will be the commodities produced under the worst conditions that regulate the market price. If, in case III, the commodities produced under favourable conditions form the greater part of the mass, then, accordingly, the market value falls below the average value. ${ }^{267}$ Uno is therefore justified in remarking that in Marx's determination, 'the qualitative dimension of market value is dissolved into the quantitative dimension'. ${ }^{268}$ This impression is further consolidated by Marx's modified determination of market value with regard to supply and demand in relation to the commodities produced at the margin. Here, the supply of commodities is regarded in relation to demand. While he insists that the mass of commodities 'not only satisfies a need, but it satisfies this need on its social scale', he proceeds:

266 Marx 1981, p. 284.

267 See Marx 1981, pp. $283-5$.

268 Uno 1962, p. 207. 
[i]f ... the quantity supplied is less than the demand, or alternatively more, this market price deviates from the market value. In the first case, if the quantity is too small, it is always the commodities produced under the worst conditions that govern the market value, while if it is too large, it is those produced under the best conditions; i.e. it is one of the two extremes that determines the market value, despite the fact that the proportions produced under the different conditions, taken by themselves, would lead to a different result. ${ }^{269}$

This modification with regard to market value seems to indicate that market value is essentially regulated by the given demand in relation to a given supply within a particular branch of production. This modified circumstance caused Uno to fundamentally question the consistency of Marx's concept of market value. What market value should explain, according to Uno, is 'the formation of a particular surplus value as the special case of the production of relative surplus value' - as e.g. how surplus profit is transformed into rent. Instead, 'in Marx, this [explanation of market value] is conflated with the fluctuations of market price arising from demand and supply' ${ }^{270}$ The accusation against Marx of a 'conflation' of market price and market value is predominant in Uno's treatment of market value in the Methodology. ${ }^{271}$ For Uno, this is not to say that demand and supply bear no relation on market value, but rather, that we can detect a correspondence in demand and supply if commodities are sold at their

269 Marx 1981, pp. 286-7. Quoted in Uno 1962, p. 207.

270 Uno 1962, p. 206.

271 Uno 1962, p. 207: 'Here, market value and market price are debated in clearly confounded fashion'. See also Itoh 1979 and Itoh 1980. For Itoh, Marx 'seems to leave us with two contradictory theories [of market value]. One of them defines market value as determined directly by the technically average conditions of production ... In contrast, Marx's second theory gives demand an important role in determining the market value'. Itoh 1980, pp. 82-3. For Itoh, unsurprisingly, Uno's theory of market value forms the solution to the 'dilemma' by defining market value as 'social value determined through the mediation of the market'. Uno 1973 [1952] p. 9o, quoted in Itoh 1980, p. 86. This, however, as we have reconstructed above, would mean us abandoning the value determination of price. On the problem of market value in Marx, also see Ehara 2017/18. Ehara, however, altogether disregards the methodological architecture of the three volumes of Capital, i.e. the assumption of a value-price-congruence in the first two volumes as a structural necessity for the explanation of their deviation in Volume III. The value-price deviation, contrary to what Ehara believes, is not an inconvenient 'concession' by Marx. Again, Uno is invoked as delivering a better explanation for market value in providing the, in fact, tautological explanation of an equilibrium of supply and demand as regulating market value. We will show to the contrary that Marx, read carefully, at no point suggests demand and supply as an independent factor for price determination, so there is no 'conflation' to speak of. 
market value, even if price appears as the regulator of supply and demand, regardless of the mass of commodities supplied at the margins (i.e. under the extreme conditions of production). Uno: 'For the quantity of commodities, Marx fixed the cases of "being too low" (kashō) or "being too high" (kadai), but in contrast, he thought he should not consider the reactions of supply and demand in his determination of market value.'272 For Uno, the determination of market value by demand and supply becomes clear when 'in the process of fluctuation, the supply towards social demand of a commodity makes the social labour in the proportion to its production necessary, and this is the way market value is determined'. ${ }^{273}$ This is the 'commodities are sold at their market value if supply and demand are in equilibrium' - variant that Marx mockingly identifies in some of his predecessors, with the distinction that Uno brings in the dimension of value as socially necessary labour. However, Uno's interjection is not unfounded: Marx indeed seems to open his conceptualisation of market value to the motive of supply and demand as an essential presupposition. But this impression is superficial and, as we argue, unfounded. If we closely regard Marx's view, his considerations with regard to a) the quantities of commodities produced at the margins (under 'worse' and 'favourable' conditions of production, respectively), and b) the quantities with regard to fluctuating supply and demand, we can see the clear causal relation between value - reflected in various prices - and supply and demand. The causality lies in the fact that value and price determine supply and demand behaviour already at the stage of production, and not just after products must be socially distributed. In this sense, 'commodities produced under favourable conditions' are simply commodities produced with e.g. a relatively low organic composition of capital, and the relatively low prices resulting from this kind of capital employment accordingly determine demand's behaviour ${ }^{274}$ - not the other way around. Marx therefore remarks:

If demand and supply determine the market price, then market price in turn, and at a further remove market value, also determine demand and supply. As far as demand is concerned, this is self-evident, since this

\footnotetext{
272 Uno 1962, p. 208.

273 Uno 1962, p. 210.

274 On the presupposition that competition forces other capitals to try to sell at similarly low prices - and diminishing their chances for a profitable return. The tendency of capital in the course of cost saving, i.e. the production of relative surplus value, to acquire smaller returns as an effect of the lowering of the value of labour power or as an effect of a continuously higher organic composition, or both, is the symptom of crisis - which lies in the form of value acquisition itself. We will return to this topic in more detail in Chapter 4.4.
} 
moves in the opposite direction to price, expanding when it falls and vice versa. But the same is true of supply. For the prices of means of production that go into the commodities supplied determine the demand for these means of production, and hence also the supply of the commodities whose supply brings with it a demand for those means of production. Cotton prices determine the supply of cotton goods ... In other words, the relationship between demand and supply does not explain market value, but it is the latter, rather, that explains fluctuations in demand and supply. 275

As we can see more clearly from this passage, the concept of market value is in no way inconsistent with Marx's value theory: demand and supply can only ever be the executors of the dominant forces of competition for a share in the rate of profit, not their cause.

Uno however takes Marx's alleged confusion with regard to market value and price as an opportunity to hint at a more fundamental misrecognition. Uno sees Marx's dissatisfactory solution to the value-price-transformation as a methodological failure to have understood clearly the subsumption of the substance under the form of value in the course of capitalist development. Let us quote the complete passage:

In his value form theory, as well as in his theory of the measure of value, Marx determines the value of a commodity by the labour time socially necessary for its production. And the value form must be explained as its indicator (hyöji suru mono). We also think the function of money as the measure of value is the indicator passing through value, and is measured as such - even if we admit the possibility of a non-correspondence between price and value. However, in a commodity-economy ... the law of value is accomplished through the fluctuation of price. The value form of the commodity, as well as money's function of the measure of value, are the forms that adjust the fluctuations of price, making value their center. That is [value's] function. As being the indicator from the beginning, passing through value in the commodity value, its specific character was lost out of sight. We cannot help but say that the substance-theoretical determination of value provided before the form determination belies the method of form theory (keitairon no hōhō wo ayamaru). In the theory of market value, this becomes clear again in the possibility of social value

275 Marx 1981, pp. 292-3. Emphasis added. 
separated from the average of the individual values. The original problem becomes conflated with the problem of the divergence of the market price from market value through the non-correspondence of demand and supply. In the theory of market value, the content of value determination that originally was the substance determination in the general theory of value, is not directly explained. As said before, while having already explained value theory, the development of a theory of market value is necessary, but it shows a peculiar aspect of the theory of commodity value. It must not simply explain the substance of value as the social substance common to all societies, but it must explain that this substance, as the substance of commodity value itself, is subsumed (hōsetsu suru) by the form determination. However, at the same time, going hand-in-hand with the subsumption itself (hösetsu suru shikatajishin ni tomonau) is the insertion of a gap (zure no ireuru men) which is an aspect that must also be explained. The explanation does not halt at the temporary deviation of price from value, which is constantly annulled by the act of the mutual adjustment between demand and supply. We need an explanation for the deviation from social value to individual value that, too, enters the form a deviation that is not merely temporal and cannot be annulled by the act of adjusting demand and supply ... With regard to the principal (genriteki) determination of commodity value, this 'grasp' [of form] over substance is given in the tendency for individual values to be united in social value. However, this can for the first time be said of the form into which the gap is inserted. From the beginning, it was no substance conforming to its form (saisho kara keitai ni soku shita jittai to shite aru wake dehanai). As against the previous theory of market value [as being the average of the individual values], Marx leaves each of these points unclear, but that is a fundamental problem of the method of proof of the labour theory of value. $^{276}$

For Uno, as argued before at the level of value theory, the specificity of capitalism does not consist in the appropriation of unpaid and alien human labour, which the value forms manage to conceal in their thing-like absoluteness. Hence, it neither consists in the social form of labour that cannot but express itself in forms of value. Abstract labour, as the substance of value, is a transhistorical fact for Uno, slightly modified by its relation to concrete labour in the capitalist production process, as discussed in Chapter 3 . What is specific to cap-

276 Uno 1974 [1962], pp. 211-12. Emphases added. 
italism, then, for Uno, is the pure form in which the law of value imposes itself on the production and reproduction process. In the real process however, prices determined in the last instance by the demand-and-supply-relation (systematically deviating from the determination of (market) value by socially necessary labour time as their 'gravitational' centre), dominate the real relations between workers and capitalists, and capitalists and workers alike. The substance of value becomes subsumed to form, form determines substance. Here, at the level of the transformation problem, we can retrospectively determine the reason for Uno's insistence on the priority of form over substance against Marx: whether in emphasising reproduction against accumulation, the sale and purchase of labour power in the circulation sphere against exploitation in the sphere of production, or the 'form determination' of price over the real labour content in the aggregate values. As argued before, it is Uno's transhistorical understanding of abstract labour, his failure to consider the historically specific form determination of labour under capitalist relations, that makes him prioritise the forms over their content - and likewise, the forms of appearance over their essential determinations. The law of value degenerates into a theory of successful social reproduction, while the central critical insight of Marx's theory of (surplus) value, namely that the law of exchange becomes a law of appropriation of alien unpaid labour, becomes ephemeral. Uno consequently collapses the difference between the actual dynamic of capitalist selfvalorisation and the 'configurations of capital' as they appear 'in the everyday consciousness of the agents of production themselves.277 If Marx were alive to read Uno's criticisms, he would probably give the following answer to Uno's understanding of the problem, as he did to the vulgar economists:

We can also understand why those very economists who oppose the determination of commodity value by labour-time, by the quantity of labour contained in the commodity, always speak of the prices of production as the centres around which market prices fluctuate. They can allow themselves this because the price of production is already a completely externalized and prima facie irrational form of commodity value, a form that appears in competition and is therefore present in the consciousness of the vulgar capitalist and consequently also in that of the vulgar economist. ${ }^{278}$

277 Marx 1981, p. 117.

278 Marx 1981, p. 300. 
According to Uno, however, the structural nexus of capital's form determinations can only be fractured by highlighting the role of use value and 'social need', what he calls the 'passive constraint of use-value'. To explain, let us briefly return to Uno's concept of market value in the Principles.

For Uno, the proportional allocation of social labour to the different spheres of industry, according to 'social need', implies 'that the supply of every product can be varied according to the changing pattern of social demand. ${ }^{279}$ Market value is therefore 'not determined by the actual content of labour per unit of the commodity but rather by the individual value of the same kind of commodity supplied at the margin'.280 The market value for Uno is therefore subject to change of supply in response to changing demand. For him, too, however, it is the equilibrium of both that is essentially constitutive of market value: 'The market value as the gravitating center of market price is determined on the basis of an equilibrium of supply and demand ... Thus, the determination of the market-value of a commodity depends upon the conditions of production under which the supply of the commodity is adjusted to demand'.281 For Marx, to the contrary, the equilibrium of supply and demand ceases to explain anything, to have 'any effect'. Rather than rely on the equilibrium of supply and demand to explain market value, then, one would have to explore the inner dynamics affecting demand (and supply). These affects reflect themselves at the conceptual level of price, which are based on a social relation completely unrelated to demand and supply, namely the paid and unpaid components of abstract human labour in the process of production. Needless to say, for Marx, total social capital must 'function' in order for accumulation to take place on increasingly expanded scales of production. This also means that a particular structure of use values must be reproduced to guarantee the material reproduction of total social capital, as he shows in Part Three of Volume II of Capital (referred to here in Chapter 4.2.). However, only here, in the discussion of the real process of social reproduction at the surface of capitalist production as a whole, can Marx prove that demand itself must obey the laws of the repro-

\footnotetext{
279 Uno 1980, p. 85.

28 o Uno 1980, p. 85. Here, 'margin' refers to Marx's statement that '[i]f ... the quantity supplied is less than the demand, or alternatively more, this market price deviates from the market value. In the first case, if the quantity is too small, it is always the commodities produced under the worst conditions that govern the market value, while if it is too large, it is those produced under the best conditions ['margins']; i.e. it is one of the two extremes that determines the market value ...' Marx 1981, p. 286.

281 Uno 1964, p. 159. Translation in Itoh 1980, p. 87.
} 
duction of capital, and not the other way around. 282 Demand (and supply) is subordinate to the fact that all individual capitals must yield an average rate of profit to belong to total social capital at all. Hence, the emergence of a general rate of profit and the transformation of values into prices of production, for Marx, is not simply a technical requirement to understand capital's inner operations. The sale and purchase of commodities at prices that guarantee an equal share in the rate of profit 'is the form in which capital becomes conscious of itself as a social power (gesellschaftliche Macht), in which every capitalist participates in proportion to his share in the total social capital. ${ }^{283}$ As a social power,

capital is indifferent to the particular use-values it produces, and in fact to the specific character of its commodities in general. All that matters in any sphere of production is to produce surplus-value, to appropriate a definite quantity of unpaid labour in labour's product. ${ }^{284}$

Uno, while trying to grasp capitalism in terms of 'pure theory', ignores or at least gravely underestimates this fact. For him, it is the aspect of use-value in terms of demand meeting supply in appropriate measures that guarantees succeeding social reproduction. He misrecognises the problematic of Marx's inquiry, namely how reproduction subordinates social needs to its own imperative of growing accumulation and still manages to foster the illusion that capitalist production is not solely directed at profit, but at demand. In other words, Uno misrecognises the problem of fetishism generated by the very social form that consolidates capital's domination over human needs. This is why the valueprice-transformation is not simply successfully solved by admitting to a systematic 'gap' inserted by the form of price into the substance of value. In fact, the value-price-transformation has little to do with Marx's 'mistake' of clearly demarcating the 'subsumption' of substance under form at all, as we will see soon. To the contrary: in order to clarify Marx's specific consciousness of the problem that Uno so dramatically misrecognises, we will offer an interpretation that views the 'transformation problem' precisely as a problem of fetishism expressing itself in the forms of its appearance. At the same time, we will point to Marx's own shortcomings in coherently applying his own method of inquiry to this crucial theorem.

282 I thank Dr. Ingo Stützle for presenting me with his ideas on the relation between the theories of reproduction in Volumes II and III of Capital.

283 Marx 1981, p. 297.

284 Marx 1981, p. 297. 


\subsubsection{The Transformation Problem as a Problem of Fetishism}

Commodities as products of capital are the results of a specific social form of labour, namely capitalist wage labour. As such, they are explicitly thematised by Marx as late as the beginning of Chapter 9 of Volume III of Capital, 'Formation of a General Rate of Profit (Average Rate of Profit), and Transformation of Commodity Values into Prices of Production'. As products of capital, commodities are always-already bearers of an average rate of profit as the result of the unity of the process of production and circulation. However, the categories of value and of surplus value are logical-conceptual presuppositions to understand the categories of profit and production price. Therefore, addressing the issue of 'value' or 'surplus value', and addressing the issue of 'production price' and 'profit' means to address two different levels of abstraction. Yet, the level of abstraction required by the category of value is presupposed in the category of prices of production. The former is based on the confrontation between capital and labour in 'purer form' than the latter, in which the basic confrontation is already obscured by the 'apparent', i.e., fetishised form of profit. The specificity of the capitalist relations of production hence does not consist in the production of a surplus product, i.e., surplus labour. Most historical relations of production presuppose a surplus product. What is decisive for the specificity of capitalist relations of production is the social form in which the production of a surplus product, as surplus value, takes place: it does not rely on personal relations of dependence, but is mediated by the exchange of formally free and equal persons. The proof of unequal exchange between capitalist and labourer on the basis of equivalent exchange is therefore not only the centrepiece of Marx's explanation for the social form that the surplus product assumes as surplus value, it is simultaneously the centrepiece for the explanation of the false illusion of equivalent exchange between capital and labour, the central fetishism of bourgeois political economy. ${ }^{285}$ Heinrich explains: 'For the analysis of the capitalist form of exploitation, surplus-value is not decisive as a quantitative category, but rather to the extent that it expresses on an abstract level the form-content (Formgehalt) of the exchange between capital and labour.' ${ }^{286}$ In rejecting the quantitative congruency between surplus value and profit in favour of the qualitative significance of the basic categories for a scientific understanding of profit, Heinrich further remarks:

285 See Chapter 6 of Capital Volume I, 'The Sale and Purchase of Labour-Power'; Marx 1976, pp. 270-80.

286 Heinrich 1999, p. 282. 
What is essential for the category of surplus-value is not the arithmetic sum of profit, interest, and ground rent, but rather that it is a 'general form', a non-empirical category that underlies the concepts of profit, interest and ground rent, and with which the visible forms on the 'surface of society' ${ }^{287}$ can be grasped. ${ }^{288}$

Especially the first chapter of Capital Volume III, in which Marx develops the categories of cost price and profit, is revealing in this regard. It probably presents the most concise analytic deconstruction of the fetish-characteristic value form of profit we can find in his complete oeuvre. The relation between surplus value and profit here presents the critical relation between the essence and the appearance of the relation between capital and labour:

In surplus-value, the relationship between capital and labour is laid bare. In the relationship between capital and profit ... capital appears as a relationship to itself, a relationship in which it is distinguished, as an original sum of value, from another new value that it posits. It appears to consciousness as if capital creates this new value in the course of its movement through the production and circulation processes. But how this happens is now mystified, and appears to derive from hidden qualities that are inherent in capital itself. ${ }^{289}$

Yet, what does it mean to say that it 'appears to consciousness as if capital creates this new value', which generates the impression that, in profit, 'capital appears as a relationship to itself'? What does it mean to say that 'surplus-value must appear as profit, profit is the transformed form of surplus value'? ${ }^{290}$ In other words, what does it mean to say that 'essence must appear'?291 In order to grasp the necessary nexus between the non-empirical, conceptual foundation of profit, and the simultaneous illusion and 'mystification' it creates by simply being itself, we must take a closer look at the determining factor of the rate of profit, i.e. cost price. As is known, the rate of profit is represented by the ratio of surplus value to the total capital invested, i.e. both constant and variable capital, or the cost price of capital ( $\mathrm{s} / \mathrm{c}+\mathrm{v}$ or $\mathrm{s} / \mathrm{C})$. It is already obvious that this shift from the rate of surplus value which only sets the ratio between surplus value

287 Marx 1981, p. 33.

288 Heinrich 1999, p. 282.

289 Marx 1981, p. 139.

290 Murray 2014, p. 192.

291 Hegel 2010 [1813], p. 418. 
and the creator of value, i.e. the variable capital employed in the production process ( $(\mathrm{s} / \mathrm{v})$, to a ratio that also accounts for the components that do not create new value, results in a lopsided view of valorisation. For Marx,

[p]rofit ... is thus the same thing as surplus-value, save in a mystified form, though one that necessarily arises from the capitalist mode of production. Because no distinction between constant and variable capital can be recognized in the apparent formation of cost price, the origin of the change in value that occurs in the course of the production process is shifted from the variable capital to the capital as a whole. ${ }^{292}$

The loss of the distinction between constant and variable capital however is constitutive to how capitalists perceive of their own act of 'advancement' of capital. Here is a first hint at how capital can 'appear as a relation to itself', namely in the fact that, for the capitalist and his 'investment', the 'capitalist cost is measured by the expenditure of capital, whereas the actual cost of the commodity is measured by the expenditure of labour'. ${ }^{293}$ Here we can detect the importance of the concept of 'transformation' for Marx, which he uses as chapter and part titles throughout Volume III:294 'transformation', for Marx, is not simply an affair of relegating the mode of presentation towards different relational quantities, co-efficients or variables. The concept of transformation, carefully chosen by Marx, denotes a reduction or even contraction, not just with regard to the informative content of our view of the problem, but of the way that the problem poses itself to the vulgar perspective. Because the notion of profit relates the 'extra' value to the total capital invested, we will only be inclined to look for the difference between capital invested and the surplus it yields, without further questioning which component of the 'value' invested is productive of new value at all - they all equally seem to yield a 'profit'. Yet, 'the category of cost price has nothing to do with the formation of commodity value or the process of capital's valorization.' ${ }^{295}$ The result of this shift or, indeed, transformation of the problematic is twofold: first, it abets the conflation of variable with circulating constant capital, muddling their respective share in the value composition of the product, and second, it abets the illusion that

\footnotetext{
292 Marx 1981, p. 127.

293 Marx 1981, p. 118.

294 As e.g., the titles of Part One and Two of the manuscripts to Volume III indicate, i.e. 'The Transformation of Surplus Value into Profit' and 'The Transformation of Profit into Average Profit'.

295 Marx 1981, p. 119.
} 
profit is necessarily 'profit upon alienation', i.e. resulting from the circulation process of capital. The latter is a result of the former. For a better grasp of this crucial theorem related to the fetishism of the bourgeois relations of production, the 'transformation' from essence to appearance, ${ }^{296}$ let us consider separately the two results of viewing all value components of cost price as equally yielding profit. As for the first problem arising from the concept of the rate of profit $(\mathrm{s} / \mathrm{C})$, this is still quite obvious. For the capitalists, the constant fixed capital used in production does not completely enter into the commodity's cost price at once and directly, but only partially (e.g. pump press machines require substitution only after several years of use). Both circulating capital and variable capital, however, appearing to the capitalist merely as costs in general, completely enter the cost price, because they are thoroughly used up in production (circulating capital as e.g. the paint needed for the fabrication of mock Olympic medals in pump pressing is physically used up after production comes to a halt). Hence, " $[\mathrm{t}]$ his difference between fixed and circulating capital in connection with the calculation of the cost price, thus only confirms the apparent origin of the cost price in the capital expended, or the price that the expended elements of production, labour included, cost the capitalist himself'. But with regard to value formation,

the variable portion of capital, that laid out on labour-power, is expressly identified here with constant capital (the portion of capital consisting of production material), under the heading of circulating capital, and the valorization process of capital is completely mystified. ${ }^{297}$

This mystification, however, is not without consequence for the theory of the source of profit. In Chapter 1 of Capital Volume III, Marx arguably presents the clearest and most condensed critique of 'circulationist' theories of profit (or rather, of 'surplus') that demonstrate the fetishistic predicament of the theorists in question - predominantly Col. Robert Torrens and his Essay on the Production of Wealth (1821) - as well as pointing to the blind spot of the mechanism in which the concept of the profit and the rate of profit obfuscate the essential relation between capital and labour in the production process. ${ }^{298}$ Two faulty premises here give rise to the fetishistic illusion that labour is just a

296 This transformation of essence to appearance, needless to say, pertains only to an analytical distinction. It does not occur anywhere in 'reality'.

297 Marx 1981, p. 124.

298 For reasons of space, Marx's critique of Torrens must be limited to sketching out the fetishistic component of circulationist theories of profit. 
value component among others: first, for the capitalist, if a commodity is sold beneath its cost price, the capital expended cannot be fully replaced. If this process continues long enough, 'the capital value will disappear completely'. ${ }^{299}$ If relations present themselves this way, it is very understandable that 'the capitalist is inclined to treat the cost price as the real inner value of the commodity, as it is the price he needs merely to preserve his capital' ${ }^{300}$ Second, however, as Marx says now with regard to Torrens, 'is the fact that the cost price of the commodity is the purchase price which the capitalist has paid for its production, i.e. the purchase price determined by the production process itself'. 301 The source of profit therefore must appear to consist in the excess value over the cost price of the commodity, realised with the sale of the commodity, in the

excess of its sale price over its value instead of an excess of its value over its cost price, so that the surplus-value concealed in the commodity is not simply realized by its sale, but actually derives from the sale itself. ${ }^{302}$

Because the difference in the costs of production and the surplus gained from the sale apparently seems to spring from the sale itself - in that the difference is thought to consist between $\mathrm{C}$ and the sales price, not between $\mathrm{k}$ and $\mathrm{C}$ - the source of profit is determined to be in the circulation process, in 'profit upon alienation. ${ }^{303}$ This argument has already been presented in the 'Contradictions in the General Formula' in Chapter 5 of Volume I of Capital. But it is not until at this exact point in the presentation, with the specification of the concept of cost price, that we finally comprehend not only that a fetishistic illusion occurs, but also why. In other words, with the analysis of the notion of profit and cost price, we can determine the mechanism by which the fetishistic view of capital as a 'self-valorising force' takes hold of capitalism's self-understanding. ${ }^{304}$ Needless to say, the fetishistic illusion of capital as a 'relation to itself', a relation of immediacy, will finally consolidate itself in the notion of interest-bearing capital. But it is already in Marx's discussion of profit that the inversion of subject and object, the structural mechanism by which capital's various fetishisms come into being, becomes central.

\footnotetext{
299 Marx 1981, p. 128.

$300 \quad$ Marx 1981, p. 128.

301 Marx 1981, p. 128.

302 Marx 1981, p. 129.

303 For this argument, see Torrens's Essay on the Production of Wealth, London 1821, pp. 51-3 and 349, quoted in Marx 1981, pp. 128-9.

304 For a similar stress on the importance of Chapter 1 of Volume III of Capital for Marx's 'deconstruction' of the conventional theories of profit, see Murray 2014, pp. 208-9.
} 
... the way that surplus-value is transformed into the form of profit, by way of the rate of profit, is only a further extension of that inversion of subject and object which already occurs in the course of the production process itself ... This inverted relationship necessarily gives rise, even in the simple relation of production itself, to a correspondingly inverted conception of the situation, a transposed consciousness, which is further developed by the transformations and modifications of the circulation process. ${ }^{305}$

Yet, if the problem at hand is one of a 'transposed consciousness' (ein transponiertes Bewusstsein), an epistemological problem arising from the capitalist mode of production itself, then why did Marx feel the need to abandon the investigation of the qualitative dimension of the relation between surplus value and profit for a quantitative solution?

First, it must be noted that the emphasis on a qualitative (or 'conceptual') problem that is at stake in the value-price-transformation, as analysed by Heinrich et al., is justified on the basis of Marx's method itself. In this sense, the transformation of values into production-prices is not a temporal-spatial act, but a conceptual-logical one. ${ }^{306}$ However, what is at stake at this point of the investigation of the relation between value and prices of production (i.e., between the rate of surplus value, indicating exploitation, and the rate of profit in which any relation to exploitation is extinguished) is precisely what 'conceptual transition' ('begrifflicher Übergang', Heinrich) is supposed to designate. This is because, by saying that the value profit rate and the priceof-production profit rate denote different 'conceptual levels', one has in fact not said much yet. We are therefore inclined to ask the following: does Marx's diagnosis of a 'transposed consciousness' involved in the emphatically unconscious transformation from values to prices (of production) deliver significant epistemological insights for his own method of demystifying the concepts of conventional political economy? And if yes, does this involve that the relation between values and prices of production is exhausted in an epistemological problematic of the qualitative relation between essence and appearance, without further application of this relation? Or did Marx, by reducing the deep epistemological, i.e. qualitative challenge related to the transformation problem to a quantitative proof of the two axioms (sum of profit = sum of

305 Marx 1981, p. 136. Note how explicitly Marx identifies the concept of 'transformation' with a fetishistic inversion.

306 Heinrich points to the obvious fact that commodities are never sold at market values, only to be later 'transformed' into market production-prices. They are market productionprices to begin with. Heinrich 1999, p. 283. 
surplus value; sum of prices of production = sum of values) at this point abandon his own fetishism-critical method and strategy? The centrality of Marx's critique of fetishism pivotal to the architecture of his intervention is specifically discussed at three conceptual trajectories: first, as the introduction to the theme of Capital, the conceptual development of value in Chapter 1 of Capital Volume I; second, in his introduction to the notion of profit in Chapter 1 of Capital Volume III; and third, in his deconstruction of the 'Trinity Formula' in Chapter 48 of the same volume. The interrelation of the three conceptual stages is crucial at this point, in that how they mediate the previous levels of abstraction with the new one is the symptom of the newly reached level of obfuscation or 'mystification'. At the same time, the analysis provides the key to unravel the mystification at hand: in the concept of profit, i.e., the notion of cost price as it presents itself to the capitalist, as well as in its real determination, we can explain how the appropriation of alien unpaid labour must disappear from the surface. The interrelation between this conceptual trajectory (i.e., value to price) and its analysis, however, is already manifested in the 'three particularities of the equivalent form' we were introduced to at the very beginning of Marx's analysis. In the equivalent form (money), it should be remembered, use value becomes the form of appearance of its opposite, value, concrete labour becomes the form of appearance of its opposite, abstract labour, and private labour becomes the form of appearance of its opposite, labour in immediately social form. These inversions are not simply one of the imagination. Money in reality becomes value, a social relation that mediates all concrete labours to one another by making them relate to itself as their common denominator, as abstract labour. In an additional further twist however, we can say that the category of value becomes the form of appearance of its opposite in the category of price (price of production and, at a further remove, market production-price). This is already obvious from the fact that money is always attached to the form of price. We can therefore add a fourth peculiarity ${ }^{307}$ to the ones Marx lists in the first chapter of the first volume of Capital. With the price form as a fourth peculiarity, the mystification is completed. The 'obvious' dynamic of capitalism, located in movements of price, altogether erases any epistemological residues of unequal exchange between capital and labour. The 'obvious' dynamic of the capitalist mode of production, however, embodied in price

307 That is, if we base our argument on the text of the 'official', the fourth edition (1890). In the first edition, the fact that the 'fetishism of the commodity-form is more striking in the equivalent form than in the relative value-form' already forms a fourth peculiarity and is not yet, as in the subsequent editions, relegated to the separate Section 4 in the first chapter. In this case, mutatis mutandis, the price form would indicate a fifth peculiarity. 
movements, is competition. Competition is the necessary condition that inadvertently leads to the equalisation of profit rates, so that it is also the inner mechanism or cause (Grund, in the Hegelian sense) for the emergence of prices of production. 'In competition, therefore, everything appears upside down',308 as Marx observes: average profits seem to be independent of the organic composition of capital, the wage level seems to determine rises and falls in the prices of production, fluctuations in market prices seem to reduce the average market price of a commodity to its production price, not to its value. Hence, at the level of Capital Volume III, the real mechanism of competition ${ }^{309}$ informs the inversion of appearance and essence in the conventional understanding:

The finished configuration of economic relations, as these are visible on the surface, in their actual existence, and therefore also in the notions with which the bearers and agents of these relations seek to gain an understanding of them, is very different from the configuration of their inner core, which is essential but concealed, and the concept corresponding to it. It is in fact the very reverse and antithesis of this. ${ }^{310}$

At this point, we can retroactively determine the fetish-character of value as it appears to us already at the very beginning of Marx's exposition in Capital. At the same time, we can finally comprehend why 'essence must appear'. Yet, the attempt to 'demystify appearance' is itself not indicative of a particular strategy. The strategy by which to achieve demystification, so to speak, lies outside its objective, is not 'automatically' provided by its intended purpose alone. We therefore confront the epistemological problem of the 'dialectic' of precondition (Voraussetzung) and result (Resultat) that Marx was very well aware of as a problem of the inversion of appearance and essence, hence of fetishism. ${ }^{311}$

308 Marx 1981, p. 311.

309 This is not to say that competition is the inner cause for capital's need to obtain a share in social production's aggregate surplus value. The contrary is the case: the necessity of individual capitals to self-valorise, i.e. obtain a share in the social surplus value, constitutes competition in the first place. In a critique of Smith's notion of competition in the Grundrisse, this becomes clear: 'Competition executes the inner laws of capital; makes them into compulsory laws toward the individual capital, but it does not invent them. To try to explain them simply as results of competition therefore means to concede that one does not understand them'. Marx 1973, p. $75^{2}$.

310 Marx 1981, p. 311.

311 'Every precondition of the social production process is at the same time its result, and every one of its results appears simultaneously as its precondition. All the production relations within which the process moves are therefore just as much its products as they are its conditions. The more one examines its nature as it really is, [the more one sees that] in 
Here, we face it in the context of the value-production price transformation: while a coherent theory and concept of value is presupposed for the analysis of cost price, profit, and prices of production, it is prices of production, or rather market production-prices, not the category of value, that we are confronted with in reality, at the surface, as that which is posited as appearance. Yet, even accepting the objective of 'demystifying' the obvious as a given - 'all science would be superfluous if the form of appearance of things directly coincided with their essence'312 - the question would be this: how did Marx even know what he was supposed to lookfor? How did 'value' become a key heuristic to defetishise the categories of bourgeois political economy - and how did it become a prerequisite by which to unravel the mystifications of capital? In the following, we will attempt to give a sketch, if for reasons of space only a brief one, of what we believe are answers to questions that Marx himself was not thoroughly aware of. In his monumental Money as Measure, Means and Method. Calculating with the Identity of Time (2014) (Das Geld als Maß, Mittel und Methode. Das Rechnen mit der Identität der Zeit), Frank Engster explores the condition of possibility of uniformly relating the different kinds of labour to one another through money. This, for him, is the fundamental epistemological question with regard to the value-price-transformation, revealing the status of Marx's critique. ${ }^{313}$ The question here follows up on the method of inquiry posed above: even if we assume that 'essence and appearance never coincide', how does the inquiry the investigation of the nature of price and a uniform rate of profit - point at 'its' inner core, namely the production of value and surplus value? Under which conditions could we, being confronted with prices only, assume their determination by value 'in the last instance (in letzter Instanz)'? ${ }^{314}$ Engster suggests that the initial question - how do we get from value to price? - should be reversed: what permits us to go from prices back to value? This important question however hints at where Marx in fact underestimates the impact of his own

the last form it becomes increasingly consolidated, so that independently of the process these conditions appear to determine it, and their own relations appear to those competing in the process as objective conditions, objective forces, forms of things, the more so as, in the capitalist process, every element, even the simplest, the commodity for example, is already an inversion and causes relations between people to appear as attributes of things and as relations of people to the social attributes of these things'. Marx 1989b, p. 507 .

312 Marx 1981, p. 956.

313 'The status of Marx's critique of value is ultimately revealed only in the transformation and inversion of price'. Engster 2014, p. 615 .

314 '... die Werte, die hinter den Produktionspreisen stehen und sie in letzter Instanz bestimmen'. Marx 1964 [1894], p. 219. Fernbach translates: '... (values) ultimately determine them'. Marx 1981, p. 311 . 
inquiry, namely that it supposes not only a quantitative, but both a quantitative and qualitative incommensurability of value and price. This is the real significance of the fetishistic illusion of the superficial presentation of the aggregate surplus value in profit rates: that they in fact do not and cannot correspond, neither in quantity, nor quality - and, yet, that they need not. We agree with Engster's view that the relation of value and price must be incommensurable, since the notion of 'price' itself is only a fetishised form of appearance of value. Therefore, we must not only concede a quantitative incommensurability concerning their magnitudes, but also of a qualitative one that points us to the fact that they address different conditions of valorisation, and, respectively, different relations of capital to itself. Engster expresses this in the notion of 'rupture' (Bruch): 'The essence of capitalist society, the valorisation of value, appears and must appear. It is not only ruptured by a definite unit (maßgebliche Einheit) [i.e. money $]^{315}$ in that this rupture itself ${ }^{316}$ makes valorisation appear at all - with this rupture by a definite unit, all labours and all capitals are put into a total social proportion (Verhältnis) and transformed into prices. This rupture both comes to appear in the prices of commodities and in money, and is simultaneously obscured in them'. ${ }^{317}$ Accordingly, the two incommensurables of value and price cannot be overcome by money as the measure of value (as e.g. in simple commodity exchange). First, Engster explains why the traditional attempts at quantitative 'solutions' to the transformation problem within the Marxist camp had to fail:

The problem of transformation seemed to consist in the fact that one and the same quality - value - appears to be quantitatively determined in different terms, in so far as the values created by labour and the final prices (of production) diverged. The transformation was reduced to the attempt of a mere conversion (Umrechnung) of given quanta (labour quanta or labour time) into equally quantitative prices of production. If however, on both sides of the calculus, determinate quantities are already treated as given, then the transformation can only mean to converse two quantities of the same quality ${ }^{318}$ and to determine their relation through

315 In literal translation, a 'measure-giving' unit: 'With money, the relation to a common unit takes place, in which all labours and commodities are put into proportion to another by mediation, in such a way that the realisation of commodity-relations also puts all labours into relation [to one another] by a definite unit of value'. Engster 2014, p. 611.

316 Emphasis added.

317 Engster 2014, p. 614.

318 Emphasis added. 
it. Moreover, the transformation of values into prices is understood as a spatial-temporal act. On the one hand, the transformation is performed as mathematical accounting (Verrechnung), which, on the other hand, must be carried out in space and time in order to put individual labour in relation to total labour in order to draw their average, and also to put the total sum of surplus value in relation to individual capitals to form the general rate of profit. The question however, which forms the basis of this transformation, namely, why the individual labours as well as their results can be put into one and the same relation and why this relation can be realised as an identical quality (a quality which consists in nothing but its quantification - this question is uncritically left aside, above all because money as the 'locus' of the transformation is completely ignored ... But while it is correct that value has no quantitative determination before price, and accordingly, in price, value quanta are not transformed, it is too hastily concluded [by Heinrich] that the level of value is merely 'conceptuallogical. ${ }^{319}$

Second, Engster argues that value can never become the object of empirical verification:

It is precisely the indeterminacy and 'vagueness' (Unschärfe) of value which ... signalises its determinacy as pure relation (a relation in and for itself) and as the reality of social mediation. ... Precisely because money is accompanied by the realised quality of 'value', and value is by all means (unhintergehbar) mediated by money and transformed into prices, the question of transformation poses itself at all. But this question must be asked in a different way than usual: because if value by all means appears as transformed into prices, and can never be known in any other way, then the transformation of values into prices must be reverted: why does it have to seem, by the appearance of prices, as though appearance was based on a previously vague, but ultimately decided relation? Why, in the category of price, does it have to seem that it results from a transformation of this relation into individual prices - a transformation, which cannot be reconstructed from determinate, given values, and which, viewed quantitatively, must rather remain indeterminate and insofar out of the scope of empirical verification? ${ }^{320}$

319 Engster 2014, p. 612. Footnote.

320 Engster 2014, pp. 612-13, footnote 155. Christoph Deutschmann has also pointed to the 
In Marx's quantitative transformation procedure it seems as though the non-empirical category of value retroactively acquires an empirical, determinate quality introduced by the concept of production price. But that would mean that values and prices were of the same inherent quality, so that the fetishistic displacement occurring through the ratio of the surplus to the total capital invested - Marx's own critical insight from the analysis of profit and cost priceno longer had a heuristic function explaining its necessarily fetishistic character. $^{321}$ Instead of emphasising the significance of the fetishistic illusion of price and the equalisation of profit rates that accounts for the 'upside down' view of conventional political economy, Marx accepts the premise of profit-rate equalisation as a fact to subsequently prove the compatibility of the sum of surplus value and the sum of profit, and of the sum of values with the sum of prices. It seems that his insights into the fetishistic character of competition and the formation of a general rate of profit, ${ }^{322}$ fostering false assumptions about the essential dynamic of valorisation, and hence, the qualitative incompatibility of value and price, 'goes by the board'323 in Marx's own quantitative transformation procedure. Against this background, attempts at denying Marx's clear claim as to the numerical equivalence of surplus value and profit ${ }^{324}$ seem untenable. Hyeon-Soo, for example, drawing on Paul Mattick's estimation, ${ }^{325}$ con-

necessary 'indeterminacy' (Unbestimmtheit) and vagueness (Unschärfe) of value as precisely its quality, in contradistinction to price. See Deutschmann 20o1, p. 99, quoted in Engster 2014, p. 612, footnote.

321 Himmelweit and Mohun seem to point at a similar argument concerning the systematic specific difference between values and prices of production: '... the development of capitalist competition does not introduce a deviation of prices from previously existing socially necessary labour-times, but instead gives those socially necessary labour-times an independent quantitative aspect they did not previously possess'. Himmelweit and Mohun 1981, p. 240 .

322 '[With the formation of a general rate of profit], [the] actual difference in magnitude between profit and surplus-value in the various spheres of production ... now completely conceals the true nature and origin of profit, not only for the capitalist, who has here a particular interest in deceiving himself, but also for the worker. With the transformation of values into prices of production, the very basis for determining value is now removed from view'. Marx 1981, p. 268.

323 Marx 1981, p. 268.

324 '... the difference in magnitude ... was simply between rate of surplus value and rate of profit, and not between surplus-value and profit themselves'. Marx 1981, p. 267.

325 "There is no direct way of discovering a commodity's price in its "value", or, by a reverse procedure, of discovering its "value" in its price. There is no observable "transformation" of values into prices; and the value concept has meaning only with regard to total social capital'. Mattick 1969, p. 25 . 
tends: 'I am convinced that Marx has nothing to do with the attempt to derive the theory of capitalist economy (sic) and the price of production, among other things, immediately from the theory of value or, which is the same, Marx never intended "to descend from the general idea of value ... by means of ever closer determinants to a direct determination of the prices of commodities". ${ }^{326}$... Value analysis does not deal with concrete capitalist relations of exchange, but especially with the disregarded and superficially unrecognisable realities, which form the basis of these exchange relations.' ${ }^{327}$ This estimation is beside Marx's point, i.e. the intent to scientifically prove the equivalence of the aggregate sums in Chapter 9 of Capital Volume III. It also misrecognises Marx's several dubious attempts to 'explain away' the unresolved problem of 'untransformed' cost prices by way of calculus. If Marx were only interested in pointing to 'unrecognisable realities' (nicht erkennbare Realitäten), he could have saved himself the whole exposition of both chapters 9 and 10 in Capital Volume III. Yet, Marx was explicit in his intention to demonstrate how the process of capital's valorisation is not only abstractly based on the appropriation of alien labour without an equivalent, but how this can be proven in the actually existing relations of production, relations in which we are confronted with the fact of the equalisation of profit rates and the existence of prices. In Engster's view, Marx himself has conceived of the fetishism already thematised in the 'three particularities' in a 'new' way in his thematisation of the value-price-transformation. This, for Engster, becomes evident in the notion of 'rupture' (Bruch). While at the level of simple commodity exchange (i.e. commodity exchange considered at the most abstract level), it is merely commodities that engage in a social relation through a 'measure-giving' (maßgebliche) unit (money), but at the level of prices of production, not commodities, but their (previous) production is put into relation with the measure-giving unity in money-price. The rupture in both cases concerns value itself - first, insofar as it pertains to the rules of value's process of valorisation (the production process of capital) and, second, its appearance in price. The rupture then includes 'the complete difference between, on the one hand, the becoming of value through its valorisation and, on the other hand, its finished appearance as price at the surface of society'. ${ }^{328}$ In the concept of price, therefore, 'the whole essence of valorisation must necessarily appear in inverted form - if only by the fact that value, while being by all means a total social relation and a total social process of valorisation, appears in the price of a

326 Korsch 1939, p. 159. Quoted in Mattick 1969, p. 49.

327 Hyeon-Soo 1995, p. 193.

328 Engster 2014, p. 615 . 
commodity in an immediate and singular, explicit and final fashion'. ${ }^{329}$ In other words, the difference between value and price can only appear as their rupture. This is especially true for the implicit argument Marx makes with regard to the fetishistic transformation - and yet, he was intent on deriving the obvious, 'apparent' form from its fundamental social grounding in value quantitatively. Interestingly, Engster's notion of rupture between the rules of valorisation in the process of production and the appearance of singularly 'explicit' prices, is quite the opposite of Uno's notion of a 'gap'. For Uno, the systematic gap in the form in which the law of value 'accomplishes' the production process, namely the 'fluctuations of price', bears no relation to the fetishistic view of the laws of valorisation itself. Hence, for Uno, Marx was wrong to hypostatise the substance of value as the guiding principle under which the forms of value assume different forms of appearance, for, in Uno's view, form subsumes substance. The process of reproduction for Uno therefore cannot be meaningfully explained by the 'substance theory of labour value' alone, but must be supplemented by the notions supply and demand in its relations to the conditions of production. The opposite is the case for Engster: because valorisation (a term Uno never uses in this context) must be reflected in commodities as the products of capital, valorisation appears as the singular price of a singular commodity - i.e. in necessarily inverted form - although valorisation always concerns the relation of the total social labour and the total capital invested in total social production.

For Uno, the 'transformation problem' does not present itself as a problem of fetishism at all - to the contrary: at this stage of the presentation, according to Uno, Marx had unwittingly confronted his own shortcomings in the theory of value. To ultimately show how this estimation owes to Uno's deep misunderstanding of the concept of value, let us turn to the law of value as the law, not of social equilibrium, but of crisis.

\subsection{The Law of Value as the Law of Crisis (Marx)}

As we have indicated above, the capitalist crisis of valorisation for Uno presents a 'breakdown' in the law of value, not a consequence of the 'law' of value itself. In the following chapter, we will counter this view by demonstrating that the theory of crisis is tantamount to the law of value itself - and vice versa. The 'law of crisis' so fundamental for understanding capitalist relations, therefore coin-

329 Engster 2014, p. 615. 
cides with the 'law of value', and more precisely, its inherent contradictions: 'To understand Marx is to understand in what sense the theory of value is the theory of crisis.' ${ }^{330}$ What follows is that Marx's theory of crisis, is the persistent underlying theme of his value theory, even if it is nowhere coherently and systematically elaborated in his published and unpublished works. What follows from this, too, is that Marx had no 'different crisis theories,', ${ }^{331}$ but only one theory of crisis. That is, no separate mechanism often associated with explaining both the secular and periodic crisis - such as underconsumption, disproportionality, or the 'law of the tendency of the rate of profit to fall' can sufficiently account for the logic of crisis already at work in the logic of an economic system solely oriented towards the appropriation of surplus value. As we will see in short, the potentiality of crisis is already contained in the contradictory character of the capitalistically determined commodity, consisting both of use value and value. While the dominant interpretative strands of underconsumption, disproportionality, and the falling rate of profit theories, can all be found in Marx at various points, none of them taken in isolation can give a holistic explanation - not of why the capitalist mode of production is bound to be 'crisis-ridden', but of why capitalism itself is the crisis, characterised by the fundamentally contradictory conditions of its (re)production and its valorisation. For Marx, the capitalist system is constituted through a processual contradiction between its 'voracious appetite for surplus labour' through constant development of the forces of production without limit, and the inner limit that capital imposes on itself in terms of profitability - not the market. The market, for capital, is only another barrier to be overcome by the unlimited development of the forces of production. Hence, the market expands and contracts according to the level of the forces of production. This phenomenon, too, is a premise given by the very way in which commodities are produced under capitalist conditions - directed solely at profit, presupposing overproduction without regard to the 'purchasing power' of the market. We will return to this crucial property of production in the forthcoming section. ${ }^{332}$ As shown

330 Bellofiore 2011, p. 95 .

331 That Marx had 'different crisis theories that can be derived from Capital' is a dominant view. See e.g. Bellofiore 2011, p. 82.

332 In his critique of Ricardo's theory of accumulation, Marx stresses that overproduction, as a result of that tendency, remains unaffected by the presumed limits of the market: 'Overproduction is specifically conditioned by the general law of the production of capital: to produce to the limit set by the productive forces (that is to say, to exploit the maximum amount of labour with the given amount of capital), without any consideration for the actual limits of the market or the needs backed by the ability to pay; and this is carried out 
in Chapter 3, the contradiction of money as the physically palpable expression of a purely social relation, value, hence, as a value form, finds its exacerbated mode of expression in capital as the more developed value form, a 'moving contradiction'. For Marx, this contradiction is inherently manifested in the very mode in which capital produces value (commodities), namely precisely by constantly depressing the value of the labour power commodity which functions as the exclusive source of value in the process of production. The production of relative surplus value, the technical term for the 'development of the forces of production without limit', coincides with real subsumption insofar as its technical employment shows not only how capital produces (commodities), but produces itself. ${ }^{333}$ Therefore, as soon as real subsumption has taken hold of the production process as a necessary, by no means contingent development of the forces of production, the inherent contradiction comes to the fore in the following way:

Capital itself is the moving contradiction, [in] that it presses to reduce labour time to a minimum, while it posits labour time, on the other side, as sole measure and source of wealth. Hence it diminishes labour time in the necessary form so as to increase it in the superfluous form; hence posits the superfluous in growing measure as a condition - question of life or death - for the necessary. On the one side then, it calls to life all the powers of science and of nature, as of social combination and of social intercourse, in order to make the creation of wealth independent (relatively) of the labour time employed in it. On the other side, it wants to use labour time as the measuring rod for the giant social forces thereby created, and to confine them within the limits required to maintain the already created value as value. ${ }^{334}$

This passage does not appear randomly in the Grundrisse. The manuscripts of the Grundrisse, as well as those of the Theories of Surplus Value, provide the fullest account of crisis in Marx's economic-critical work. It is worthwhile to mention that the writing of the manuscripts was accompanied by what counts as one of the first worldwide economic crises in history, the 'finan-

through continuous expansion of reproduction and accumulation, and therefore constant reconversion of REVENUE into capital ...' Marx 1989b, pp. 163-4.

333 '... it is necessary to describe the circulation or reproduction process before dealing with the already existing capital - capital and profit - since we have to explain, not only how capital produces, but also how capital is produced'. Marx 1989b, p. 143.

334 Marx 1973, p. 706. 
cial panic' in the United States of 1857-61. Both Marx and Engels were intrigued by this first 'global' crisis, and Marx concentrated his theoretical efforts on elaborating on its cause. ${ }^{335}$ The $1857-8$ manuscript of the Grundrisse hence takes its vantage point from the critique of the predominant theories of money, exemplified in Proudhon and Proudhonians like Darimon. It also provides a rich source for Marx's conceptualisation of crisis that he, not too accidentally, developed alongside his theory of surplus value. The kernel of his theory of production, circulation and distribution from which he develops the concepts of his critique of the political economists (necessary labour, surplus labour, surplus value, the rate of surplus value, etc.) has been first developed in this unpublished manuscript, and the corresponding passages in the later 1861-3 manuscripts (Theories of Surplus Value). References to the fundamental theory of crisis, in the metamorphosis of the commodity, and in the contradiction of money as a means of circulation and means of payment, are also delivered throughout Capital, but in his later work, references to crisis are more scattered. In the next section, we will look at the topic of the inherent contradiction of the capitalist mode of production, predominantly expressing itself in money, more closely, both in the Grundrisse and in the Theories of Surplus Value, as well as Capital. After that, the much debated issue of the law of the tendency for the rate of profit to fall', of which we have only Engels' account in the third volume of Capital, will be elucidated as one expression of the more fundamental contradiction that manifests itself as the result of the rising organic composition of capital, which however itself results from the 'development of the forces of production without limit' and the production of relative surplus value. In this context, we are well advised to look more closely at the rejection of Marx's proof of the falling rate of profit, prominently formulated by Michael Heinrich, to draw attention to not only the unfinished character of the context in which the law is formulated, but also its questionable foundations as a systematic law of crisis. We attempt to show that Marx, similarly to his underestimation of his own fetish-critical method with regard to the transformation problem, the law of the tendency of the rate of profit to fall' presents much less an insight into his own analytical framework as the framework that he otherwise confronts political economy with, namely that the 'drive' to valorisation contradicts its own foundations in the process of circulation: the production for the sake of surplus value (profit). The discussion of Marx's view on crisis will conclude with the expression of the fundamental contradiction of a mode of produc-

335 See Goldberg 1987. 
tion that is solely oriented towards tearing down the barriers to the creation of abstract wealth, and precisely by tearing down these barriers, reproduces them at a higher and more conflicted level.

These accounts serve to put Uno's theory of business cycles and his equilibrium theory of social reproduction into the context of Marx's own conceptualisation. At the end of this chapter, we will therefore revisit aspects of Uno's theory of 'crisis' in the Principles, insofar as we haven't discussed them yet. ${ }^{336}$ Uno's emphasis of the supply of labour power as the sine qua non of capitalist production, so that the expansion of production with the given technical method is potentially unlimited, ${ }^{337}$ as well as his rejection of the possibility of overproduction, will be countered with Marx's understanding. Again, this chapter will draw attention to Uno's theoretical parallels with classical bourgeois economy, especially Ricardo, in their view of crisis. Finally, and in contrast to this, we hope to demarcate the ways in which Marx, much rather than offer a technical-mechanical 'theory' of crisis, as Simon Clarke puts it, '[offers] a fundamentally different foundation for the analysis of the capitalist economy from that on which bourgeois economics is built.'338 In that sense, it is because of the contradictory process of the development of the forces of production, due to the appropriation of surplus value and the conditions of profitability of the same surplus value - a contradiction not even fathomed by his predecessors that, for Marx, the theory of crisis lies 'at the heart' of the critique of political economy. 339

\subsubsection{The Inherent Contradiction of the Capitalist Mode of Production (1): Money}

What is an economic crisis? Before we come to Marx's 'deflated' definition - the possibility of a crisis is already given in the separation of purchase and sale in

336 Within the theory of the business cycle which we have briefly presented in 4.1., Uno has more specifically a) a theory of surplus population, b) a theory of cyclical crisis in relation to the renewal of fixed capital, and c) a theory of a cyclical falling rate of profit based on 'profit squeeze', which are all loosely connected. They will be discussed later in this chapter.

337 '... there is no inherent limit to the accumulation of capital so long as capital is well supplied with labour-power, which it cannot directly produce, in the form of surplus population. Hence, so long as labour-power is available, there is no theoretical reason why capital may not continue to expand its production with the given technical method'. Uno 1980, p. 88.

338 Clarke 1994, p. 285.

339 See Clarke 1994, p. 279. 
the capitalistically produced and therefore money-mediated commodity - let us turn to a more general definition generally in line with the macroeconomic view:

An economic crisis is a situation in which the reproduction of an economic unit is suddenly compromised, typically when it is unable to meet its contractual obligations. A crisis may be generalised from one unit to the system as a whole, with the crisis being transmitted through a breakdown of the financial system as one failure provokes others and undermines the confidence of investors. ${ }^{340}$

A good theory of capitalist crisis should not only cover the ground relating to the specific instances where this inhibited valorisation occurs, or which sectors of the economic system it may expand (i.e. financial system, banking) but should be able to encompass the conditions of the problem to include the foundations on which the distribution or circulation of total social capital rests, and that is the process of production. Hence, in the Grundrisse, Marx observes that

The result at which we arrive is, not that production, distribution, exchange and consumption are identical, but that they are all elements of a totality, differences within a unity. Production is the dominant moment, both with regard to itself in the contradictory determination of production and with regard to the other moments. The process always starts afresh with production. That exchange and consumption cannot be the dominant moments is self-evident, and the same applies to distribution as the distribution of products. As distribution of the agents of production, however, it is itself a moment of production. A definite [mode of] production thus determines a definite [mode of] consumption, distribution, exchange and definite relations of these different moments to one another. $^{341}$

340 Clarke 1994, p. 74. For Joseph Schumpeter, one of the few bourgeois theorists who takes crisis seriously as a theoretical problem, this 'inherent' character of economic crisis is not a necessity: 'Of course, there can be no doubt that the phenomenon of crisis essentially belongs to the sphere of the economy. But it is by no means certain that it belongs to the essence of the economy, or even to just some economic form in the sense that it necessarily results from the effects of factors in the economy left to themselves'. Schumpeter 1911, p. 417. Original emphasis. Translation our own.

Marx 1986 [1857-61], 36. 
An adequate theory of crisis therefore 'must be a theory of the dynamics of the capitalist mode of production which establishes the tendency to crisis as something inherent in those dynamics. ${ }^{342}$ This is precisely Marx's claim to his own theory with which he confronts conventional political economy. Quite an influential theory of both money and crisis in Marx's time was Proudhon's and his school's, which forms the starting point of Marx's criticism in the Grundrisse. The passage quoted above sets the methodological tone for the critique of Proudhonist positions and especially their view of crisis.

'The Chapter on Money', which forms the first part, begins with a review of Darimon's De la Réforme des Banques (1856). By the 185os, Proudhonian socialism has moved away from questions of social distribution and the view of property as 'theft' and shifted its emphasis to circulation, especially of money and the means of consumption. In sum, the Proudhonian socialists believed that the ultimate cause for crisis was to be detected in the obstacles to commodity circulation (commodities as means of consumption), caused by the shortage of money. They saw capital and money precisely as a hindrance to free exchange relations, a position already held by Proudhon in his early 'Qu' est-ce que la propriété?' (1840). ${ }^{343}$ Proudhon's followers 'believed that a system of free credit, unconstrained by the limits of metallic convertability [hence the idea of 'labour certificates' and the 'People's Bank'] would eliminate both the capitalistic exploitation of the producers by the bankers, and the periodic crises to which the system of metallic money gave rise. ${ }^{344}$ They equally rejected a revolution of the conditions of production which would overcome the antagonistic social classes in the production process - capitalists and labourers since they primarily regarded bankers as the beneficiaries of the economic system, not the capitalist class as a whole. By the same token, they did not view the capitalist system as one in which private property of the means of production presented the differentia specifica against other historical formations. This view of money shortage as the cause of crisis made Marx formulate a per-

\section{Clarke 1994, p. 74.}

343 See Proudhon 1994 [1840].

344 Clarke 1994, p. 125. See Darimon, in De la Reforme des Banques (Paris 1856): 'Donc, dironsnous à notre tour en manière de parenthèse, c' est à ce privilège, dont jouissent l'or et l'argent, d'être les seuls instruments authentiques de circulation et d'échange qu'il faut attribuer non-seulement la crise actuelle, mais les crises périodiques qui frappent le commerce. C' est à cause de cela que les banques, au lieu de venir en aide à l'industrie dans ces moments difficiles, n' ont jamais servi qu' à précipiter sa ruine.' Darimon 1856, p. 6. See also: 'The root of the evil is the predominance which opinion obstinately assigns to the role of the precious metals in circulation and exchange.' Original quote in Darimon 1856, pp. 1-2. Quoted in Marx 1973, p. 115. 
tinent critique of 'quantitative money theories' (also conducted against the currency school in the Contribution and the third volume of Capital). At the same time however that the Proudhonists demand 'free credit' (crédit gratuit) to circumvent the obstacles to consumption, they reject money and strive to abolish the money form as universal equivalent by bestowing 'all commodities' with the monopoly of purchase. ${ }^{345}$ Instead, labour certificates should substitute metallic money, the 'root of the evil'. ${ }^{346}$ In his critique, Marx made clear often polemically - that Darimon failed to understand the difference between the need for money as money (unifying the functions of being the measure of value/measurement of prices and means of circulation) and the need for money merely as means of circulation. Most of all however, Darimon failed to comprehend that the character of money as the universal equivalent already presupposes a particular form of social production:

The real question is: does not the bourgeois system of exchange itself necessitate a specific instrument of exchange? Does it not necessarily create a specific equivalent for all values? One form of this instrument of exchange of this equivalent may be handier, more fitting, may entail fewer inconveniences than another. But the inconveniences which arise from the existence of every specific instrument of exchange, of any specific but general equivalent, must necessarily reproduce themselves in every form, however differently. ${ }^{347}$

The misconception of solving the limited means to the access of consumption by either inflating the quantity of money or by wresting the monopoly position from metallic money to 'debase' gold and silver as the 'gods of commodities', is based on the failure to comprehend the function of money as the mediator of the different kinds of labour in one specific commodity, and likewise on the failure to see money as 'abstract-general, social labour'. ${ }^{348}$ Hence, in

345 'Then you no longer have the specific evils of gold and silver money, or of notes convertible into gold and silver. You abolish all evils. Or, better, elevate all commodities to the monopoly position now held by gold and silver. Let the Pope remain, but make everybody Pope'. Marx 1973, p. 126.

346 Darimon 1856, p. 1. Quoted in Marx 1973, p. 115.

347 Marx 1973, p. 127.

348 Marx 1989b, p. 135. Here is not the place for a general critique of Proudhonism. Suffice it to say that Proudhon, in Brentel's words, is the paradigmatic 'theorist for the necessary semblance of the bourgeois mode of production, the semblance of simple circulation' (Brentel 1989, p. 209) in that Proudhon takes simply commodity exchange to represent the essence of capitalist relations, devoid of the conceptual presuppositions of unequal 
a crisis, commodities (in the form of commodity capital) remain unsold - not because there is not enough money to effect the exchange, but because there is nothing 'against which they can be exchanged'. ${ }^{349}$ The problem is not the shortage of money as the means of circulation to facilitate exchange, but a shortage of money as equivalents for the commodities themselves: precisely because in a crisis money no longer fulfils the function as a measure of values, as a measure of the socially necessary labour time expended in production, the commodity cannot be sold. In other words: in a crisis, money no longer measures the labour time of the commodity it is confronted with - it is no longer 'valuable'. Inflation only abets this problem - while the quantity of money grows, its value diminishes, and is less and less capable of representing the value of commodities. In this respect, in a crisis, inflating money as a means of circulation will never solve the more fundamental problem of money's incapability to function as the measure of value. In a situation of crisis, therefore, capitalists cannot realise the value of their commodities. In money, we already confront the basic contradiction between its function as a means of circulation and its function as the measure of value: '... none of [the various forms of money] can resolve the contradictions inherent in the money relationship, they can all only express these contradictions in one form or another.' ${ }^{350}$ The task then would be to determine the character of money at its most basic level to see how the germ of crisis already consists in the concept of money itself.

\subsubsection{The Inherent Contradiction of the Capitalist Mode of Production (2): Say's Law}

The metamorphosis of the commodity is a good indicator for a more general view of this task. In relation to the metamorphosis, in the Grundrisse, the 186163 Economic Manuscripts, and Capital, Marx makes the most 'abstract' obser-

exchange between labour and capital that Marx's analysis of the money already contains. Unlike Marx who views the contradiction between use value and value as an objective phenomenon at the heart of the contradiction in the capitalist mode of production, Proudhon saw the contradiction between value and use value merely as a principally rectifiable flaw within capitalist relations. This understanding ultimately culminates in a normative-subjective theory of value, directed towards a harmonic system of exchange where commodities are always exchanged in 'just' proportions of the directly and immanently measured labour time they contain. For Proudhon, money is therefore not a specific social relation necessitated by the objective contradiction between value and use value, but a corrigible flaw of a principally harmonious system of exchange in capitalism. For a detailed account of Proudhon's economic views, see Brentel 1989, pp. 187-242.

$35^{\circ}$ Marx 1986 [1857-61], p. 61. 
vations in relation to crisis. The discussion of the potentiality and actuality of crisis is here embedded in a critique of the dominant law of classical - and today, neoclassical - economy: Say's Law, on the one hand, and Ricardo's theory of accumulation on the other. ${ }^{351}$ Let us first deal with Marx's critiques of Say's Law as a problem of the contradiction manifested in money and exchange before we move on to Marx's critique of Ricardo's theory of accumulation as a problem of the contradiction in production, the latter which can be considered the culmination of Marx's critical insights. According to the influential French economist Jean-Baptiste Say (1767-1832), '[a] product is no sooner created, than it, from that instant, affords a market for other products to the full extent of its own value'.352 For Say, in sum, crises on the market cannot occur, because 'every seller brings his own buyer to the market with him'. ${ }^{353}$ Say's Law therefore postulates that every sale is a purchase and every purchase a sale, implying a general equilibrium. Marx confronts the equilibrium theory of social reproduction which we have already encountered in Uno on three levels: a) in the formal or 'abstract' possibilities of crisis in the simple metamorphosis of the commodity, b) in the misrecognition of the relations of capitalist production in which capital confronts the labourer not as 'consumer'/'customer', but as the living source of profit, and c) in the substantial reality of overproduction crisis, conditioned by the tendency of the total growth of capitalist production (unconditioned by the market). Let us consider these three objections, which appear unsystematically over the Grundrisse, the 1861-63 Economic Manuscripts, and Capital, in a more systematic form:

a) Directing his argument against J.B. Say, for Marx, the metamorphosis of the commodity, C-M-C, already presupposes that the sale of the commodity potentially does not happen smoothly at all. It is here, in simple circulation, that the formal possibility of crisis already becomes apparent: ${ }^{354}$

351 The relation between the two is obvious since, as Brentel observes, 'Marx criticises Ricardo because of the adaptation of Say's harmonious model of reproduction, according to which no general overproduction of commodities, or "no general glut of the market" ... is possible, and points to the origins of this view in James Mill who insinuates a "metaphysical balance of sellers and buyers", a view that developed into the claim of the identity of supply and demand being solely determined by production itself'. Brentel 1989, p. 163 .

352 Say 1834 [1803], p. 138. Also, for Say, '[as] each of us can only purchase the productions of others with his own productions - as the value we can buy is equal to the value we can produce, the more men can produce, the more they will purchase'. ibid., p. 3 .

353 Marx 1976, p. 208.

354 Marx here only presents the most formal and abstract exchange (simple circulation) in which the concepts of credit, profit and fully established capitalist relations are not yet considered. Economists, however - like J.S. Mill for example - mistake their own presentation resting on barter or money-mediated barter for developed capitalist exchange rela- 
The possibility of a crisis, in so far as it shows itself in the simple form of metamorphosis, thus only arises from the fact that the differences in form - the phases - which it passes through in the course of its progress, are in the first place necessarily complimentary and secondly, despite this intrinsic and necessary correlation, they are distinct parts and forms of the process, independent of each other, diverging in time and space, separable and separated from each other. The possibility of crisis therefore lies solely in the separation of sale from purchase. ${ }^{355}$

According to Marx, "[nothing] can be more foolish than the dogma that because every sale is a purchase, and every purchase a sale, the circulation of commodities necessarily implies an equilibrium between sales and purchases'. ${ }^{356}$ The commodity is useless if it is not converted into money. However, even when 'the first difficulty'357 - the metamorphosis C-M - is solved, the new owner of money does not need to immediately purchase a use value, i.e. throw her money back into circulation. The immediate identity of the exchange of one's own product with the acquisition of someone else's is split up into two processes which are not necessarily reconcilable: hence the possibility of crisis already at the level of simple circulation. The necessity of an inner unity of the autonomously existing acts of purchase and sale hence must manifest itself 'violently', i.e. in crisis - which gives proof that their 'internal unity moves forward through external antitheses. ${ }^{358}$ It is the inverted presentation of use value in value, concrete in abstract labour, performed by the universal equivalent, money, which presents a barrier to the act of exchange. Exchange exacerbates the fetish character of money at the level of circulation. Marx contends:

There is an antithesis, immanent in the commodity, between use-value and value, between private labour which must manifest itself simultaneously as directly social labour, and a particular concrete kind of

tions and therefore only 'explain the possibility of crises, by no means explain their actual occurrence. They do not explain why the phases of the process come into such conflict that their inner unity can only assert itself through a crisis, through a violent process'. Marx 1989b, p. 133. Marx does not so much criticise the attempt to only present the 'possibility' of crisis - which he does himself - as the fact that economists like Mill take the presentation of crisis in simple circulation for a presentation of fully developed relations. See Marx 1976, p. 209, footnote 24 and Marx 1973, p. 198.

355 Marx 1989b, p. 133 .

356 Marx 1976, p. 208.

357 Marx 1989b, p. 138.

$35^{8}$ Marx 1976, p. 209. 
labour which simultaneously counts as merely abstract universal labour, between the conversion of things into persons and the conversion of persons into things; the antithetical phases of the metamorphosis of the commodity are the developed forms of motion of this immanent contradiction. ${ }^{359}$

Again, as with the Proudhonians, Say and his followers misrecognise the deeper characteristics of the role of money. They fail to see it as the mediator of different kinds of privately performed concrete labour in a social context, as abstract labour, and therefore as the materialisation of any, and, at the same time, no particular kind of labour. In direct or money-mediated barter, as which the classical economists, including Say, view the exchange of commodities sub specie aeternitatis, not capitalis, ${ }^{360}$ this difficulty does not arise. ${ }^{361}$ Here, exchange takes place because what is demanded is use value, and money only 'facilitates' this process. If the end of the exchange is a particular use value, there should be no reason why every purchase should not be a sale and vice versa. Under these 'eternal laws of human interaction' or the 'proclivity to exchange', i.e. under the conditions of barter, the equalisation of supply and demand, in which Say and also Uno believe, is indeed possible. But these economists forget that in a capitalistically determined money economy, the difficulty of transforming a commodity - the particular product of individual, concrete labour - into its opposite, money - abstract-universal, social labour - is that 'money does not appear as the particular product of individual labour',362 so that 'the person who has effected a sale, who therefore has commodities in the form of money, is not compelled to buy again at once, to transform the money again into a particular product of individual labour.'.63 This is the way of a society in which use value is not the aim of production. Like Say, Ricardo is unaware about the specific character of money as the expression of abstract and general human labour, and reduces money to a simple means of exchange of a more or less 'balanced' exchange process, directed towards use value. Marx therefore con-

\footnotetext{
359 Marx 1976, p. 209.

360 In contrast to Marx who views these relations 'sub specie capitalis, not sub specie aeternitatis'. Marx 1987, p. 13 .

361 See also the corresponding passage in the Grundrisse: 'After the economists have most splendidly shown that in barter, in which both acts coincide, does not suffice for a more developed form of society and mode of production, they then suddenly look at the kind of barter which is mediated by money as if it were not so mediated, and overlook the specific character of this transaction'. Marx 1973, p. 198.

362 Marx 1967 [1861-63], p. 510. Own translation.

363 Marx 1989b, p. 139. See also Clarke 1994, p. 169.
} 
tends that Ricardo's insights mark 'a return not only to the time before capitalist production, but even to the time before there was simple commodity production; and the most complicated phenomenon of capitalist production - the world market crisis - is flatly denied, by denying the first condition of capitalist production, namely, that the product must be a commodity and therefore express itself as money and undergo the process of metamorphosis. ${ }^{364}$ What follows from this is that precisely because production is oriented towards the production of value and surplus value, not use value, and hence not directed towards social need, there is no necessary relation established between the supply of commodities as use values and the demand for them. ${ }^{365}$ In capitalism, to use this infamous term for once, use values are only ever produced because they serve as the bearers of (surplus) value, not to satisfy a need. From this also follows that the market cannot have the function of limiting or expanding demand. Demand in fact does not present a decisive criterion for production at all. It is therefore also in the context of the contradiction inherent in production itself, not only in the contradiction inherent in the exchange of commodities, that Say's Law must be confronted. Marx does so by rejecting the impossibility of overproduction implied by Say's Law and reiterated by Ricardo. Needless to say, our context shows that the arguments directed against them must be repeated against Uno's claim that 'generally, overproduction does not occur'. 366 Before we move to confronting the problem of general overproduction, let us confront a further problem in Say's Law:

b) In the beginning of the section on the 'Contradictions between Production and Consumption under the Conditions of Capitalism. Transformation of the overproduction of leading articles of consumption into general overproduction' in Notebook XIII of the Theories of Surplus Value, which addresses Ricardo, Marx discusses the conditions of reproduction and consumption of labourers (in both his own and Ricardo's example, weavers). Ricardo, as a follower of Say's Law and like Say himself does not acknowledge the possibility of general crisis or a crisis of overproduction because the exchange of the total social aggregate should always happen without obstruction - every commod-

364 Marx 1989b, p. 132. (MECW 32).

365 Clarke 1994, p. 127.

366 Uno 1964, p. 207. Uno: 'The phenomenon of crisis is not directly caused by an overproduction of commodities. Both the means of production and the articles of consumption that capital requires for its expanding reproduction are produced, as they are socially regulated by the movements of prices, so that no general over-production of commodities is theoretically possible [rather: 'so that, generally, overproduction does not occur']. Some partial over- and under-production of commodities are indeed unavoidable, but these must eventually be corrected by the movement of prices'. Also see Uno 198o, p. 121. 
ity will find its buyer. But what about the product that the direct producers, the labourers, do in fact produce themselves, like machinery, but do not buy? The labourer herself does not own the conditions of the means of the realisation of her own labour. She is not a 'customer' or 'consumer' of capital in the circulation process - even if she, by expending her labour power, 'consumes' capital in the process of production by producing new value. But she can never represent demand for any other commodities than those which enter into individual consumption: ${ }^{367}$

Hence nothing is more ridiculous than to speak of the identity of producers and consumers, since for an extraordinarily large number of TRADES - all those that do not supply articles for direct consumption the mass of those who participate in production are entirely excluded from the purchase of their own products ... This also shows the ambiguity of the word consumer and how wrong it is to identify it with the word buyer. As regards industrial consumption, it is precisely the workers who consume machinery and raw material, using them up in the labour process. But they do not use them up for themselves and they are therefore not buyers of them ... nothing is more absurd as a means of denying crises, than the assertion that the consumers (buyers) and producers (sellers) are identical in capitalist production. They are entirely distinct categories. $^{368}$

This is already apparent in the fact that the landlord does not produce anything, but consumes - and the same goes for 'moneyed interest', i.e. the banking sector. Say's Law, to sum up, fails as soon as it is employed upon the actual relations of the capitalist mode of production. Because the contradictions of this mode of production, most notably the contradiction between capital and wage labour, are 'erased in their imagination' (wegphantasiert), they cannot develop an adequate theory of crisis.

c) In the problem of overproduction, the formal contradiction embodied in money, has hence turned into a substantial one. Marx here confronts Say's

367 With the presentation of the 'Reproduction Schemas' in Chapter 4.2., we have seen that $\mathrm{v}$ can only ever substitute a part of the invested capital, never the total capital invested. Hence, Marx not only rejects equilibrium theories like that of Destutt de Tracy, which claim that the consumers buy back what they produce (see Marx 1978, pp. 556-65), but also rejects theories of crisis that see the failure in social reproduction to 'find buyers' for the aggregate products, i.e. theories of underconsumption.

368 Marx 1989b, pp. 147-8. 
Law to demonstrate the actual tendency, and not just the possibility of overproduction. The tendency of overproduction cannot be circumvented by the 'regulation of the market', since the market itself is fundamentally dependent on the development of the forces of production. It may appear as though a shortage in money, as the Proudhonians believed, hampers the realisation of value. But in order to understand that this 'formal' barrier to valorisation has its origin in the 'substantial' one in the way that general capitalist production is organised, we have to look at the implications of the realisation of surplusvalue. Indeed, the first systematic (not temporal) barrier the total social product (consisting of commodities) confronts is the transformation of the products into money, as we have seen in the contradictory moments within exchange. In a second step, however, it is not only the value that has to find its money equivalent to realise the product, but the product's surplus value. This surplus value, again, must meet its monetary equivalent in order to be realised. The problem of extended reproduction is therefore confronted with the conversion of a surplus value consisting in commodities into even more money, as we have seen in Chapter 4.2. But the money equivalent of the surplus mass of commodities cannot be 'conjured out of thin air (nor created by a banker)'. ${ }^{369}$ Marx, methodologically presupposing 'capital in general', not individual capitals, shows in Volume II of Capital that the money for the realisation of the surplus comes from the other capitalists involved at a different point in the total circulation of the aggregates. As Clarke observes:

[The money for the realisation of the surplus] can only exist if capitalist production has also taken place elsewhere, producing an equivalent surplus value embodied in commodities against which the first can be exchanged. Behind the need for a consumer of the increased production, therefore, lies the need for another capitalist producer whose activity will have promoted the increase in demand ... Behind the growing market required to absorb the growing product, therefore, lies the systematic growth of capitalist production..$^{370}$

This 'systematic growth' can only express itself in a general overproduction. Consequently, the market constitutes no external barrier to this systematic growth. It is solely conditioned by the mode of existence of the capitalist form of production, the production oriented towards surplus value, neither towards

$369 \quad$ Clarke 1994, p. 134.

$370 \quad$ Clarke 1994, p. 134. 
needs, nor towards 'the consumer'. This is yet another way in which Say's Law or the law of a necessary equilibrium is based on dubious foundations when it is confronted with the organisation of capitalist production.

\subsubsection{The Inherent Contradiction of the Capitalist Mode of Production (3): Overproduction}

If, however, the inner barrier to capitalist production is not set by the market or consumption, but by the organisation of production in terms of profitability itself - how does it work? And how does the fundamental contradiction the development of the productive forces without limit and the limit simultaneously set to the very foundations of the same development, namely the reduction of the value of labour power - necessarily culminate in general, and not just a partial, overproduction as the overarching feature of capitalist crisis?

In a passage in the Grundrisse (where Marx also for the first time introduces the concept of necessary and surplus labour to describe the method of increasing productivity), he pertinently characterises how capitalist production must always tear down the barriers to its valorisation in terms of value.

... since capital represents the general form of wealth - money - it has a boundless and measureless urge to exceed its own limits. Every boundary is and must be a barrier for it. Otherwise it would cease to be capital, money reproducing itself. If a particular boundary were not to be a barrier for it, but one to which it could confine itself without difficulty, capital would itself have declined from exchange value to use value, from the general form of wealth to a particular substance of it. ${ }^{371}$

The systematic growth of capitalist production confronts itself in the realisation of value, i.e. the circulation process. It is here that capital must face its barrier set by its own mode of organising social reproduction oriented towards value. Paradoxically however, capital, whose raison d'être is the production of commodities containing value and surplus value, cannot comply with itself when confronted with its own mode of the realisation of that (surplus) value, namely in circulation. Overproduction under the conditions of capital is therefore not an overproduction 'bare and simple', understood as an overproduction of 'products': rather, it is an overproduction of commodities, values and capitals, hampered by the lack of moneyed demand. ${ }^{372}$ It is decisive here that money

371 Marx 1986 [1857-61], pp. 259-6o.

372 'The world OVERPRODUCTION in itself leads to error. So long as the most urgent needs 
steps between supply and demand. In other words, for succeeding reproduction on an ever extended scale, 'demand' bare and simple is not enough: capitalist reproduction demands moneyed demand, and better even, 'surplusmoneyed' demand, which again depends on the conversion of the surplus product of other capitalists into surplus money, and so on - a completely fragile process. In more precise terms therefore, overproduction as the cause for crisis is simultaneously the cause for the crisis of reproduction, but reproduction not on an even, but a constantly expanding scale. Under the conditions of the need for reproduction on a higher scale, therefore, supply and demand do not regulate (re-)production at all. To the contrary: the irrational production of surplus value for the sake of surplus value, mediated by moneyed demand, constantly shakes up the equilibrium of supply and demand. An equilibrium is the exception from the rule, not the rule. In other words: the market cannot serve as a limit to production, because production is by its own standards limitless. Hence, it is not demand that gives the incentive to production, but the production of profit itself. The contradiction of value and use value therefore manifests itself on the substantial level: disproportionality does not only express itself as an 'imbalance' of production, but as general overproduction. Furthermore, on the substantial level of the organisation of production itself, we can see how the lowering of the value of labour power to extend its use value is the precise expression of that contradiction. The substantial contradiction within production itself is therefore two-fold: capitalist production is directed at 'general wealth', at money, not at any particular wealth, expressed in any use value. Hence the breakdown of theories that view social reproduction primarily serving the need of social reproduction by the consumption 'in the private lives of workers themselves.'373 Money (capital) as the 'living con-

of a large part of society are not satisfied, or only the most immediate needs are satisfied, there can of course be absolutely no talk of an overproduction of products - in the sense that the amount of products is excessive in relation to the need for them. On the contrary, it must be said that on the basis of capitalist production, there is constant underproduction in this sense. The limits to production are set by the profit of the capitalist and in no way by the needs of the producers'. Marx 1989b, p. 156 .

373 Uno 1980, p. 52. And yet Uno seems to be unaware that what he terms the muri (the 'impossibility') of labour-power. i.e. that labour-power is the only commodity capital cannot directly produce which therefore relies on non-capitalist forms of 'reproduction' and is not subsumed to capital's logic, is the precise condition of capital's valorisation to take place - and not, as authors of the Uno tradition such as Bell (Bell 2009) would have it, forming a potential 'use value space' of resistance against capital. That this view is mistaken can be shown in Patrick Murray's spot-on commentary on the role of 'domestic labour': 'The ordinary point of paying wages is to reap profits. But profits can be reaped from household labour only on the assumption that it produces commodities with a big 
tradiction' radicalises the opposition of value and use value in the commodity, precisely by materialising the crisis of valorisation. We saw this in the above discussion of money's failure to represent the measure of value characterising a crisis on the level of exchange (formal possibility of crisis). Second, and more pertinently, the contradiction of value and use value here consists in the contradiction between necessary labour and the total labour (necessary plus surplus labour) expended in the production process. It characterises the crisis in the structure of production itself: the proportions are constantly shifted towards diminishing the proportion of necessary against surplus labour. It is here that the inner barrier to capitalist production results from the internal foundation of this mode of production itself:

The stages of production which precede capital appear, when looked at from the standpoint of capital, as just so many fetters upon the productive forces. But capital itself, correctly understood, appears as the condition for the development of the productive forces only so long as they require an external spur, a spur which at the same time appears as their bridle. It is a discipline over them, which at a certain level of their development becomes quite as superfluous and burdensome as [previously] the corporations, etc. These inherent limits must coincide with the nature of capital, with the essential character of its very concept. ${ }^{374}$

The inherent limits are those of 1 ) necessary labour as the limit to the exchange value (value) of the living labour capacity, 2) surplus value as the limit of surplus labour and the development of the forces of production, 3) money as the limit to production and 4) the limitation of the production of use values by value: 'The limits to production are set by the profit of the capitalist and in no way by the needs of the producers'. ${ }^{375}$ Hence overproduction is 'a sudden reminder of all these necessary moments of production based on capital. ${ }^{376}$ In order to answer why the tendency to overproduction is not just a partial, but a general phenomenon, or why partial crises are always generalised, it is useful to remain a little with Marx's critique of Ricardo's theory of accumulation and

surplus-value. But what would those commodities be? Wage-labourers? ... In a system of unfree labour, you cannot exploit workers in the capitalist manner: without wages, there is no gap between wages and the value produced by workers. Where there is no gap, there is no surplus-value ... Without surplus-value, there is no capital'. Murray 200o, p. 131.

375 Marx 1989b, p. 156.

376 Marx 1986 [1857-61], p. 342. See also Marx 1953 [1857-8], p. 319. 
crisis, in order to highlight the convergences of his approach with that of Uno. Both Ricardo and Uno, as had been shown before in the case of Uno, generally deny the possibility of general overproduction.

In general, for Ricardo, as long as there is demand for the products of capital, capitalist production is limitless. ${ }^{377}$ The competition of capitals sees to the conditions of proportionality of production, so that overproduction or a general glut of the market is impossible. ${ }^{378}$ On these grounds, the possibility of crisis expressed in a lower profit rate can only occur as an effect of rising wages which themselves are a quasi-natural result of the growth of the national populace. ${ }^{379}$ Ricardo develops this as a counterargument against Smith's conception of crisis as the result of competition. Against Ricardo, Marx points out that the 'disproportionality' of production countered by competition itself however presupposes a crisis tendency of this production mode itself - proportionate production is, however, always only the result of disproportionate production on the basis of competition' 380 - so that Ricardo fails to see that competition itself imposes a constant tendency to disproportionality. Competition however only reinstalls proportionality 'through the pressure to develop the forces of production in order to reduce the labour time necessary to production', in other words, precisely by driving 'capitalist production constantly beyond those limits. ${ }^{381}$ Competition is therefore capital's external, and yet self-imposed contradiction, a contradiction arising from the 'rules of the game' of valorisation itself. However, it only 'executes the inner laws of capital. It does not invent them'. ${ }^{382}$ But precisely by being guided by the principle of competition as its executor, the dynamic of the law of value (valorisation) coincides with the dynamic of the law of crisis in the first place. It is true that, next to the drive imposed by

377 'It follows then ... that there is no limit to demand - no limit to the employment of capital while it yields any profit, and that however abundant capital may become, there is no other adequate reason for a fall of profit but a rise of wages ...' Ricardo 1969 [1817], p. 197.

378 'That is why Ricardo admits that a GLUT of certain commodities is possible. What is supposed to be impossible is only A SIMULTANEOUS, GENERAL GLUT in THE MARKET'. Marx 1989b, p. 158.

379 '... and further it may be added, that the only adequate and permanent cause for the rise of wages is the increasing difficulty of providing food and necessaries for the increasing number of workmen'. Ricardo 1969 [1817], p. 197. Agricultural production is the decisive sector here: Because with general social development and a growing population, capital will increase, and so will the demand for labour. The demand for it may accordingly rise in greater proportion than the supply for it. See Ricardo 1969 [1817], pp. 55-6.

$380 \quad$ Marx 1989b, p. 15 o.

$381 \quad$ Clarke 1994, p. 142.

$382 \quad$ Marx 1973, p. $75^{2}$. 
competition, supply and demand can provide a counter-tendency to disproportionality in production, because in such a case, e.g. in a leading commodity of consumption, its price will fall. However, since the production and the provision of commodities to the market are temporally separated, demand can only have an ex-post effect to counter overproduction of that particular commodity. What happens is devaluation and the destruction of productive capacity in the overextended branches of production. This however leads to a generalisation of the losses of overproduction, because the capitalists in question will now save their costs in their purchase from other capitalists. Consequently, money influx to these other branches of capital is hampered, so that, theoretically, reproduction cannot continue on the same or even an expanded scale. The distinction made by classical economists between 'particular' and 'general' overproduction is therefore 'entirely spurious', as Clarke points out. ${ }^{383}$ In sum, 'the momentum of the development of production in any branch is not determined by the demand for the product, but by the opportunities for acquiring a surplus profit by advancing the productive forces' ${ }^{384}$ However, if Ricardo's failure to see the inherent contradiction of capitalist production is conditioned by his 'bourgeois standpoint' alone, how do we classify Uno's very similar estimation? Before we come to a closer look at Uno's aspects of periodic crisis in the Principles, let us sum up what we have already presented in this chapter as Uno's theory of value as the law of general equilibrium, and in the previous chapter as Uno's 'formal' theory of money. Recall that Uno hypostatises 1) the role of money and commodity as 'circulation forms' subsuming the capitalist production process and 2) the latter as a system of social reproduction, as 'common to all social formations', so that

[the] unfolding of the circulation forms of the commodity, money, and capital, when clarified to grasp the production process at the basis of the capital form, must explain the labour-and-production process as the social substance that is common to all social formations ... The labour process common to all societies is subsumed under its specific social forms. ${ }^{385}$

383 Clarke 1994, p. 143. This is less Marx's than Clarke's own argument, concluded from Marx's remarks in the Grundrisse: 'In fact, the departure from the given proportion in one branch of production drives all the other branches out of that proportion, and at unequal rates'. Marx 1986 [1857-61], p. 341.

384 Clarke 1994, p. 143.

385 Uno 1974 [1962], p. 29 o. 
We have also seen that money, for Uno, unlike Marx, does not conceal a particular social relation, namely abstract labour, under its palpable shell. Money is only valuable as it is useful, for Uno, in its exchange for use values, measured by the subjective evaluation of the commodity owner of the linen (i.e. the commodity in the relative form of value). Hence, for Uno, 'if we say that it is labour through which the value of a commodity is constituted, we have definitely not understood the value of a commodity'.386 Furthermore, we have seen that for Uno, circulation determines production. In lieu of a critical response to Uno, let us hear instead Marx's own critical summary of Ricardo:

If Ricardo thinks that the commodity form makes no difference to the product, and furthermore, that commodity circulation differs only formally from barter, that in this context the exchange value is only a fleeting form of the exchange of things, and that money is therefore merely a formal means of circulation - then this in fact is in line with his presupposition that the bourgeois mode of production is the absolute mode of production, hence it is a mode of production without any definite specific characteristics, its distinctive traits are merely formal. He cannot therefore admit that the bourgeois mode of production contains within itself a barrier to the free development of the productive forces, a barrier which comes to the surface in crises and, in particular, in overproduction - the basic phenomenon in crises. ${ }^{387}$

Like Ricardo, Uno denies the secular tendency to crisis which is conditioned by the substantial contradiction of the capitalist production mode - the development of the forces of production without limit and the limits to the same development set by the law of value - because, like Ricardo, Uno perceives of the capitalist mode of production in mere formal terms. In other words, precisely because Uno only considers the forms without the content in his 'pure theory of capitalism', he is blind to the content hidden by these forms. With regard to the equilibrium of profit rates, furthermore, Uno claims that '... capital possesses the faculty of allocating itself to the various spheres of production so as to supply all the products that society demands' ${ }^{388}$ and, with regard to the satisfaction of the 'commodity-economic norms', Uno says:

386 Uno 1973 [1947], p. 312.

$387 \quad$ Marx 1989b, p. 156.

388 Uno 198o, p. 76. 
In all societies, the continuation of annual reproduction depends on the distribution of both labour power and the means of production in the two departments (of social production), in accordance with the degree of social demand. This presents nothing but the implementation of the norms (gensoku) existing as a matter-of-fact in the rational process of economic life, and equally pertaining to all societies that assume the commodity form. A capitalist commodity-economy realises this norm through the law of value, which is regulated by and asserts itself in the movement of price. Capital, in other words, provides every sector of production with labour power and means of production in order to, with the given labour time necessary for the production of individual products, satisfy social demand. ${ }^{389}$

This view is close to both Say's and Ricardo's view of general social reproduction in which supply always meets its proportional demand. It is only logical that in such a society, 'generally, overproduction cannot occur. ${ }^{390}$ What does Marx have to say on this?

All the objections which Ricardo and others raise against overproduction, etc., rest on the fact that they regard bourgeois production either as a mode of production in which no distinction exists between purchase and sale - direct barter - or as social production, implying that society, as if according to a plan, distributes its means of production and productive forces in the degree and measure which is required for the fulfilment of the various social needs, so that each sphere of production receives the quota of social capital required to satisfy the corresponding need. This fiction arises entirely from the inability to grasp the specific form of bourgeois production and this inability in turn arises from the obsession that bourgeois production is production as such, just like a man who believes in a particular religion and sees it as the religion, and everything outside of it only as false religions. ${ }^{391}$

Unlike Ricardo, needless to say, Uno perceives bourgeois production as a 'specific form'. However, he resorts to an understanding of that form which halts at being formal. This is implied in his idea of the general equilibrium which believes that the reproduction of total social capital is exhausted in aiming to

389 Uno 1964, p. 116.

390 Uno 1964, p. 207.

$391 \quad$ Marx 1989b, p. 158. 
show that 'capitalist society too satisfies ... the fundamental condition of simple and expanded reproduction which all societies must satisfy', ${ }^{392}$ eliminating not only the critical impetus of Marx's analysis, but also naively subsuming capitalist reproduction under a quasi-natural law of the need for reproduction in which society 'sees to' providing its own self-sustenance: instead of seeing that the reproduction of that society is not only a constant administration of crisis, but takes place in the mode of the subordination of humans to the law of value. In this sense, Uno's strangely un-Marxian understanding of capitalist society also receives an apologetic moment in its approach to capitalism as mere formality that has no bearing on Marx's critique of the bourgeois relations of production.

\subsubsection{The Systematic Crisis Tendency of Capital: The Problem of Marx's Law of the Tendency of the Rate of Profit to Fall}

For Marx, the tendency of general overproduction was not the only problem associated with the historical tendencies of capital to develop the forces of production without limit. The historical tendencies towards unlimited production manifested themselves in different ways, which, however, all contribute to a general tendency for crisis.

Just as the transformation of values into prices of production presented the one big challenge to Marx in his attempt to overcome the contradictions and insufficiencies of classical political economy, especially in Ricardo, the coherent and 'law-like' explanation for the tendency for a falling rate of profit presented the other big challenge for Marx as he tried to expose the 'fallacies' of his predecessors. Indeed, the discovery of the law, for Marx, as he has written in a letter to Engels, presented 'one of the greatest triumphs over the pons asinorum of all previous economics'. ${ }^{393}$ Marx considers his own intervention in giving a law-like explanation of the fall in the rate of profit, which had already been asserted by Smith and Ricardo, in the following way:

And given the great importance that this law has for capitalist production, one might well say that it forms the mystery around whose solution the whole of political economy since Adam Smith revolves and that the difference between the various schools since Adam Smith consists in the different attempts made to solve it. If we consider, on the other hand, how previous political economy has fumbled around with the distinction between constant and variable capital, but has never managed to formu-

392 Uno 198o, p. 58.

393 The letter is dated 30 April 1868. See Marx 1983, p. 137. 
late this in any definite way; how it has never presented surplus-value as something separate from profit, nor profit in general, in its pure form, as distinct from the various constituents of profit which have attained an autonomous position towards each other ... how it has essentially never analysed the differences in the organic composition of capital, and hence has not analysed the formation of the general rate of profit either - then it ceases to be a puzzle that political economy has never found this puzzle's solution. ${ }^{394}$

We will return to this crucial quote, as it points to the specific character of the intervention Marx aimed at.

In general, Marx develops the Law of the Tendency of the Rate of Profit to Fall, LTRPF in short, on the basis of a rising organic composition of capital (OCC) which itself is the result of the general tendency of capital to develop the forces of production without limit, i.e. the production of relative surplus value as the economically most pertinent phenomenon of the real subsumption of labour under capital. For Marx therefore, against Smith and Ricardo, a falling rate of profit is considered as one of the phenomena resulting from the general historical tendencies of capitalist accumulation, i.e., the production of relative surplus value and incessant revolutionising of production, itself. It is therefore not a direct historical, but a systematic explanation of crisis. That is, even if the secular tendency of the falling rate of profit is not necessarily inevitable - depending on class struggle or the counteracting tendencies capitalists will employ (rising rate of exploitation, cheapening of constant capital, shortening the turnover time) - any measurement to counter the tendency for diminished returns is likely to reintroduce precisely the factors by which the 'fundamental barrier to valorisation' is reproduced at a higher level. ${ }^{395}$ In other words, the massive cost saving procedures capital employs to intensify both the intensive as well as the extensive expansion of production, undermines the desired effect of increasing returns, and instead leads to the tendency of their general decline, which in the long-term could manifest itself in crisis. Historically, the tendency to crisis may manifest itself more directly through general overproduction, in that on the one hand, the greater the mass of surplus value, ${ }^{396}$ the greater will be the mass of commodities to be realised through

394 Marx 1981, p. 320.

395 We will return to this point at the end of this chapter.

396 In fact, the mass of surplus value $\mathrm{s} / \mathrm{v} \cdot \mathrm{V}$ may also rise while the rate of profit declines. Marx discusses a specific case where the surplus value of an individual capital rises, but its relation to the total capital invested in this branch of production, i.e. the profit-rate, declines 
their sale to other capitalists, and therefore more vulnerable to the crisis of reproduction. On the other hand, and more clearly, as a historical tendency, the rising OCC and the growing mass of surplus value is associated with the general law of accumulation, i.e. the concentration and centralisation of capital, a growing relative surplus population, pauperisation, and a growing polarisation of capitalist society, as we described it in Chapters 2.2. and 4.1. Yet, as against this historical tendency of capitalist accumulation, the LTRPF is 'the most important law of modern political economy'397 for Marx, ${ }^{398}$ so that it can hardly be ignored in the context of elucidating Marx's view of crisis. Since Uno was well aware of the importance of this law, we shall also briefly discuss Uno's view of it within the context of the Principles. As said before, an increase in the OCC is a consequence of the growing productivity of labour in which each labourer processes a greater quantity of raw material. ${ }^{399}$ What exactly is meant by the term 'organic composition of capital'? Since a cost-intensive constant capital may be processed by either many or few labourers, it is difficult to relate the value relation directly to the technical relation of capitals. To understand, therefore, how a growing productivity of labour will diminish the value of labour power and shift the relation between the value composition and the technical composition of capital, Marx introduces the concept of the organic composition of capital which is the value composition of capital 'in so far as it is determined by its technical composition and mirrors changes in the latter'400 A rising OCC is therefore the direct consequence of productive techniques in which more constant capital is employed and the value of labour power in relation is diminished, even if the total number of workers rises. In other words, it is accompanied and sustained by the production of relative surplus value. Needless to say, the cost saving procedures in terms of wages do allow individual

(see Marx 1986 [1857-61], pp. 306-10). He uses this to counter, on the one hand, Bastiat's mistaken notion that profits on machine-intensive capital advanced must necessarily be smaller than on labour-intensive capitals (for Marx, this depends on the surplus labour performed, not on the composition of capital). On the other hand, he counters Ricardo's 'profit-squeeze' theory of declining profits through higher wages. Marx 1986 [1857-61], p. 311.

397 Marx and Engels 1987, p. 133.

398 Clarke doubts the plausibility of this claim. The formulation of the law 'does not appear at all in any of the works which Marx published in his own lifetime. In Volume One of Capital ... the organic composition of capital plays a central role, but in relation to the law of population, not that of the tendency for the rate of profit to fall'. Clarke 1994, p. 166. This may be, however, because in the only work on the critique of political economy published in Marx's lifetime, Volume I of Capital, the concept of profit is not yet developed.

399 Clarke 1994, p. 159.

$400 \quad$ Marx 1976, p. 762. 
capitals to reap an 'extra profit' - but only until this procedure has become generalised in this same branch of production. Average profit always evens out on the basis of the latest cost saving technological process (commodities produced under 'favourable conditions'), so that this 'tendency' of a falling rate of profit becomes a general feature that catches even the most profitable individual capitals in its vortex. How does Marx, then, prove the actual 'law'? First, he assumes a constant rate of surplus value and a rising $0 \mathrm{cc}$, which accordingly shows the decline in the rate of profit (either viewed temporally, as successive capital compositions of one capital, or simultaneously, different increasing OCC in different capitals):

$$
\begin{aligned}
& \text { if } c=50 \text { and } v=100, \text { then } p^{\prime 401}=100 / 150=662 / 3 \% \\
& \text { if } c=100 \text { and } v=100, \text { then } p^{\prime}=100 / 200=50 \% \\
& \text { if } c=200 \text { and } v=100 \text {, then } p^{\prime}=100 / 300=331 / 3 \%, \text { etc. }{ }^{402}
\end{aligned}
$$

From this, it is clear that if we assume (1) p s s c c+v, the formula for the rate of profit, and a growing occ while the rate of surplus value remains constant, we can express the LTR PF in the formula $(2) \mathrm{p}=(\mathrm{s} / \mathrm{v}) /(\mathrm{c} / \mathrm{v})+1$. To which Marx says:

If we further assume now that this gradual change in the composition of capital does not just characterize certain individual spheres of production, but occurs in more or less all spheres, or at least the decisive ones, and that it therefore involves changes in the average organic composition of the total capital belonging to a given society, then this gradual growth in the constant capital, in relation to the variable, must necessarily result in a gradual fall in the general rate of profit, given that the rate of surplus value, or the level of exploitation of labour by capital, remains the same. ${ }^{403}$

Note that this assumption is based exclusively on the hypothesis of the inner secular tendency of capital to develop the forces of production without limit, which must always be reflected in a growing occ and increasingly machineand technology-intensive investments. As a fundamental assumption, the rate of surplus value remains the same.

It is precisely Marx's basic assumption, namely that the rate of surplus value remains the same (while the possibility of a rising rate of surplus value has been deferred to a mere 'counteracting tendency' by Marx), which has drawn

\footnotetext{
401 The rate of profit, expressed in percentage.

402 See Marx 1981, p. 317.

403 Marx 1981, p. 318.
} 
fierce objections to the law. To explain the LTRPF and the terms of its applicability as a systematic expression of the crisis tendency of the capitalist mode of production, it seems almost impossible to ignore the critique it has faced, as well as heated debate that has formed around the concept in Marxian economics in the last years. However, for reasons of space, we must abstain from a detailed evaluation of these debates. ${ }^{404}$ In short, however, among the many objections, especially from Heinrich, lurks the assumption that the LTRPF and the phenomenon of the rising occ obscures a more fundamental claim concerning the crisis of realisation related to the law of value itself. Let us shortly review two positions related to this claim. In his article on 'Crisis Theory, The Law of the Tendency of the Rate of Profit to Fall, and Marx's Studies in the 187os', Heinrich gives a comprehensive overview of the development of Marx's drafts of Capital from the Grundrisse to the final manuscripts in relation to crisis theory, with a particular emphasis on the Law of the Tendency of the Rate of Profit to Fall (LTRPF) as it is now presented in Volume III of Capital, in Engels's heavily edited version. Heinrich draws attention to both the editorial problematic of the LTRPF's presentation, and also the objective inherent problems of demonstrating the law to claim that Marx 'does not succeed' 405 in demonstrating the law as such. As for the relationship between the LTPRF and the 'counteracting factors', Heinrich points out that Marx assumed the fall in the profit rate would in the long run outweigh the counteracting factors - without providing a proof for this. In short, Heinrich's critique of the law itself consists in showing that Marx 'failed' to prove the law within the framework of its own conditions, for the condition of rising productivity would entail both a rise in the rate of surplus value and a rising occ. If, as Heinrich claims, the formulation of the 'law' rests on contradictory assumptions, so that Marx 'failed' to prove the LTRPF from within the secular tendencies of capitalist development

404 The evaluation of the LTRPF debate sparked by Heinrich's essay 'Crisis Theory, the Law of the Tendency of the Rate of Profit to Fall, and Marx's Studies in the 187os' in Monthly Review in 2013 (see Heinrich 2013), with subsequent commentaries by Guiglielmo Carchedi/ Michael Roberts, Fred Moseley, and Shane Mage, had originally formed a part of this chapter. It is however probably better suited for a separate article which we consider for future publication, especially because Heinrich's assessment of the law has in the meantime drawn further criticism in the German debate. Hans-Peter Büttner, for example, argues that Heinrich adopts a neo-Ricardian framework he otherwise rejects, by accepting the 'Okishio theorem' and hence physical, and not monetary, inputs and outputs. See Büttner 2017. The 'round-table on Heinrich' was conducted online: https://monthlyreview .org/commentary/critique-heinrichs-crisis-theory-law-tendency-profit-rate-fall-marxs-st udies-187os/.

405 Heinrich 2013, p. 22. 
as such, we would have to concede that this 'most important law of modern political economy' is altogether a red herring and might as well be discarded. Supplementing this with Marx's own view of crisis, Heinrich argues that there are reasonable doubts that Marx himself considered the LTRPF as crucial to understanding the 'law of value', as a fundamentally contradictory law inherent to the appropriation of surplus value: 'The most general formulation of capitalism's tendency to crisis is completely independent of the "law of the tendential fall in the rate of profit"; rather, its starting point is the immediate purpose of capitalist production, surplus-value or rather profit' ${ }^{\prime} 06$ Heinrich provides textual proof from Marx's own discussion of the LTRPF in Volume III of Capital to show that '[here], a fundamental problem becomes apparent':407

The conditions for immediate exploitation and for the realization of that exploitation are not identical. Not only are they separate in time and space, they are separate in theory. The former is restricted only by the society's productive forces, the latter by the proportionality between the different branches of production and by the society's power of consumption. And this is determined neither by the absolute power of production nor by the absolute power of consumption, but rather by the power of consumption within a given framework of antagonistic conditions of distribution, which reduce the consumption of the vast majority of society to a minimum level, only capable of varying within more or less narrow limits. It is further restricted by the drive for accumulation, the drive to expand capital and produce surplus value on a larger scale ... The market, therefore, must be continually extended ... the more productivity develops, the more it comes into conflict with the narrow basis on which the relations of consumption rest. It is in no way a contradiction, on this contradictory basis, that excess capital coexists with a growing surplus population; for although the mass of surplus-value produced would rise if these were brought together, yet this would equally heighten the contradiction between the conditions in which this surplus-value was produced and the conditions in which it was realized. ${ }^{408}$

It is this contradiction - the contradiction between the conditions for the production of surplus value and the conditions for its realisation - that, according to Heinrich, provides a more fundamental framework for the systematic

406 Heinrich 2013, p. 26.

407 Heinrich 2013, p. 26.

408 Marx 1981, pp. 352-3. 
tendency to crisis than the LTRPF: 'Hence, Marx points out a fundamental contradiction between the tendency towards an unlimited production of surplusvalue, and the tendency toward a limited realization for it'.409 The realisation of surplus value, however, has nothing to do with 'advocating an underconsumptionist theory' here, because 'also the investments of businesses ... determine the relationship between production and consumption. ${ }^{410}$ Yet, Heinrich clearly conceptualises the 'crisis of realisation' in terms of unsuccessful circulation. We will contest this view in our interpretation of the LTRPF towards the end of this section. In consequence, no matter how much Marx stresses the importance of the law, we have to consider that he did not invent the LTRPF 'for its own sake'. Clarke concurs: 'The fundamental issue is the historical tendencies of capitalist accumulation, of which the tendency for the rate of profit to fall is only one aspect to be considered in the wider framework'.411 Accordingly, in Clarke's view, the LTRPF was only one approach to explaining the inherent contradiction of the capitalist mode of production based on its drive to expand the forces of production without limit. ${ }^{412}$ The LTRPF therefore is neither sufficient nor necessary to explain the correlation of the two, Clarke contends. Despite the objections the LTRPF has faced, it has also been made useful as a 'meta-theory' of crisis. In this sense, Riccardo Bellofiore argues that the 'law' must not be understood as a 'consequence of the rise of the composition of capital', but as a 'meta-theory of the crisis, which includes within it other and different theories of the crisis',413 i.e. 'not only the so-called underconsumptionist and the so-called disproportionality lines about the realization crisis, but also the tendency to the capitalist crisis that originates directly in the social relations of production within the immediate process of valorisation'414 This roughly corresponds to the contradiction between the conditions of production and that of the realisation (or the successful circulation) of surplus-value. Bellofiore however deemphasises the role of a rising occ in favour of the crisis of realisation, which springs from the 'counteracting tendency' of increasing the rate of surplus value. Here, a further motion can be noticed: '... precisely the force repressing the crisis [the increase in the rate of surplus value] pushes

\footnotetext{
409 Heinrich 2013, p. 26.

410 Heinrich 2013, p. 26.

411 Clarke 1994, p. 223.

412 'The progressive tendency for the general rate of profit to fall is thus simply an expression, peculiar to the capitalist mode of production, of the progressive development of the social productivity of labour'. Marx 1976, p. 319. The original says 'ein' (one) der kapitalistischen Produktionsweise eigentümlicher Ausdruck, not 'the' expression.

413 Bellofiore 2011, pp. 82-3.

414 Bellofiore 2011, p. 92.
} 
the system toward a third, different kind of crisis; the crisis of realization'. ${ }^{415}$ But how does Bellofiore argue for a crisis of realisation without advocating a onceand-for-all underconsumptionist interpretation of crisis? To be sure, Bellofiore admits that an 'effective consumer demand' theory of crisis 'seems in contradiction to Marx's reproduction schemes that show how demand to capital comes from capital itself, directly or indirectly'416 The predicament lies in the fact that capital, so to speak, cannot have its cake and eat it too: any counteracting tendencies to the falling rate of profit, such as the rising rate of surplus value, while beneficial to productivity, hamper the successful realisation of profit, in the restitution of the initial $v$. This intensification of the 'tendency to the fall of the relative wage' also affects extended reproduction, by shaking up the 'ratios of exchange, which are necessary for stable-extended reproduction (in equilibrium):417 But neither Heinrich nor Bellofiore can thoroughly circumvent the problem that both their rejections viz. reformulations of the LTRPF in favour of 'realisation crisis' virtually end up with the problem of underconsumption. While this may be a partial explanation to crisis - wages can only ever substitute the v-component of the capital invested, but never realise the surplus - we believe that the significance of the LTRPF lies elsewhere: namely in the scathing critique of the crisis-theoretical framework of the classics, which is simultaneously the critique of their value-theoretical framework. To briefly contextualise the setting of the problem, we believe, it is therefore more useful to carefully consider Marx's own intent - at least in a rough sketch - with the presentation of the law as a direct refutation of the classics. This is because the rising occ, despite Heinrich's and Bellofiore's dismissal of its relevance, here plays a significant role as a direct critique of the understanding of the law of value, notably in Smith and Ricardo, who had no notion of the organic composition, and hence, the value composition of capital.

As has been pointed out by Heinrich, a falling rate of profit had already been acknowledged by Smith and Ricardo as an empirical phenomenon, while the explanation differed: Smith (faultily) saw the falling rate of profit as the result of competition, ${ }^{418}$ while for Ricardo, only the rise of wages could lead to a fall in the rate of profit, conditioned by a growing population which would have

\footnotetext{
415 Bellofiore 2011, p. 89.

416 Bellofiore 2011, p. 9 .

417 Bellofiore, p. 9 o.

418 This view is contested by L. Tsoulfidis and D. Paitaridis who argue, with ample documentation, that Smith's theory of falling profits is linked more closely to the evolution of interest rates and rising wages, seeing competition much rather as a result than a cause for falling profit rates. Tsoulfidis and Paitaridis (2012). Competition, after all, is also one of the factors (though not the cause) of falling profit rates for Marx.
} 
to reproduce itself from continuously less fertile land, implying a higher price of grain. ${ }^{419}$ Marx in turn criticised Ricardo for failing to see that productivity increases in grain are possible either with a falling or rising price of grain. But while Marx was, strictly speaking, not the first to point out the secular tendencies of a falling rate of profit, he was the first to claim to have 'discovered a coherent explanation for this law' ${ }^{420}$ Indeed, 'Marx does not assume any particular form of market or conditions of competition, but rather solely the form of development of the forces of production typical of capitalism, the increasing deployment of machinery'. ${ }^{211}$ The method is hence based not on 'empirical evidence', even if that may have been the case, giving the re-occurring crises since the late 185 os. $^{422}$ The method rather rests on proving the law from the inner tendencies of capital itself. And here is where we can pick up the golden thread that runs through the analysis of the fetishism of political economy: precisely by conflating value and price, and surplus value and profit, Smith and Ricardo were not only unable to explain the origin of capital on the basis of equal exchange, they were also blind to the different properties in the composition of capital, which led both Smith and Ricardo to draw the line of demarcation between fixed and circulating capital, instead of variable and constant capital. Ultimately, both labour and means of production were sources of value for Smith and Ricardo, a theoretical predicament that blocked the way to a clear understanding of the cause for the crisis of accumulation. The organic composition of capital and its internal changes accompanying the development of productive forces thus remained anathematic to them, leading to an internally inconsistent theory of crisis. In Ricardo's case, the search for an 'invariable' measure of value further obscured the origin of surplus value, the 'pure form' of profit: for the working day, the measure of value, is not invariable - necessary and surplus labour assume different proportions in it. But that does not mean it is not absolute, to the contrary: as an absolute measure of value, it is variable, but nevertheless an 'absolute', i.e. not relative (dependent on a different factor) explanation of the source of value. Hence it was crucial for Marx to stress the importance of a growing OCC as a heuristic framework for crisis, since it was

\footnotetext{
419 See Heinrich 2013, p. 21.

420 Heinrich 2013, p. 21.

421 Heinrich 2013, p. 22.

422 Since especially these crises did not occur so much in 10 year-period cyclic outbreaks, as Marx had believed earlier, but, with the relatively short time span between the 1857-8 and the 1861 crisis, happened more frequently, however less eruptively. See Clarke 1994, pp. $263-4$.
} 
systematically obscured from the elaborations of the classics who ultimately did not hold a labour theory of value in any meaningful sense of the term at all.

The LTRPF is therefore significant as a further development of Marx's labour theory of value as a critique of the classics, in that it clarifies, for Marx (to return to the previous quote) how previous political economy has fumbled around with the distinction between constant and variable capital, but has never managed to formulate this in any definite way ... how it has essentially never analysed the differences in the organic composition of capital, and hence has not analysed the formation of the general rate of profit either'. Keeping in mind capital's only objective however - the drive towards infinite accumulation and profitability, and the means to obtain it - 'then it ceases to be a puzzle that political economy has never found this puzzle's solution'. ${ }^{423}$ In other words, the law of value as the law of crisis lies in the form of capital itself:

Capitalist production constantly strives to overcome these immanent barriers, but it overcomes them only by means that set up the barriers afresh and on a more powerful scale. The true barrier to capitalist production is capital itself. It is that capital and its self-valorization appear as the starting and finishing point, as the motive and purpose of production; production is production only for capital, and not the reverse, i.e. the means of production are not simply means for a steadily expanding pattern of life for the society of producers. The barriers within which the maintenance and valorization of the capital-value has necessarily to move - and this in turn depends on the dispossession and impoverishment of the great mass of the producers - therefore come constantly into contradiction with the methods of production that capital must apply to is purpose and which set its course towards an unlimited expansion of production, to production as an end in itself, to an unrestricted development of the social productive powers of labour. The means - the unrestricted development of the forces of social production - comes into persistent conflict with the restricted end, the valorization of the existing capital. If the capitalist mode of production is therefore a historical means for developing the material powers of production and for creating a corresponding world market, it is at the same time the constant contradiction between this historical task and the social relations of production corresponding to it. ${ }^{424}$

423 Marx 1981, p. 320.

424 Marx 1981, pp. 358-9. Emphasis added. 
Not so much a 'crisis of realisation', then, in terms of successful exchange of the aggregate product with workers (and capitalists) forming the other pole of the contradiction to the mode of production in underconsumptionist terms, ${ }^{425}$ but a crisis of the realisation of maximum profitability, in that the value product increasingly represents less surplus value (the s component in $\mathrm{c}+\mathrm{v}+\mathrm{s}$ ), and hence less money, unable to reap profits that would compensate over and above the invested capital, and thus increase over time, which the term 'extended reproduction' - capital's modus operandi - designates. In other words, even if workers continue to 'buy back' the v-share of the full aggregate product, and the capitalists provide a monetary equivalent to realise its entire c-share and the surplus value, profits 'melt', 426 returns decrease. As we have seen in our discussion of overproduction, money can only realise what the process of production provides in terms of value. If the commodities contain less value, then less money is needed to realise this value. Money cannot create value 'out of thin air'. Hence, the crisis of capitalist production is not caused by unsuccessful monetary circulation, because even successful monetary circulation does not circumvent decreasing returns. This is the precise meaning of the contradiction between the conditions of the production and the conditions of the realisation of value and surplus value: ${ }^{427}$ the character of production itself the production of profit - undermines its own realisation: 'Circulation, or the exchange of commodities, creates no value' 428 - and no surplus value either.

If we place this result of Marx's analysis of crisis against Uno's view of the 'law of value' in which production and consumption fall into magical har-

425 This would be the level of the argument conducted in Volume II of Capital. Marx shows that successful circulation, even 'without an equivalent', is possible - but only if one abstracts from capital's sine qua non of developing the forces of production without limit. On the basis of the production of relative surplus value, which accompanies and sustains this development, however, the realisation of ever greater shares in profit is hampered. The theoretical framework of the LTRPF is the production of relative surplus-value in Volume I of Capital, not the reproduction schemes.

426 We here lean on the general crisis-theoretical framework of the Wertkritik school (predominantly Robert Kurz and Claus Peter Ortlieb), without necessarily sharing their dystopian conclusions. In general, Wertkritik proposes a 'value dissolution' theory of crisis (Wertabschmelzung) in terms of the diminishing mass of surplus value produced by all productive workers, or conversely, the mass of surplus value contained the aggregate value product (Ortlieb 2014, p. 78). To our knowledge, this is the only theory coherently developing the notion of crisis from the conceptual framework of the production of relative surplus value. For English translations of central texts, see Larsen et al. (eds.) 2014.

427 We consider this clarification necessary in light of Heinrich's and Bellofiore's imprecise notion of 'realisation'.

428 Marx 1976, p. 266. 
mony - not only of the initial separation of production and circulation, but also into a harmony of interests of workers and capitalists - we can see that Marx's view is not only the opposite, but that its theoretical interest also radically differs: while Marx's interest is critical, Uno's intervention - in line with his endeavour to present the 'principles' of a 'pure capitalist society' - must refrain from critical assumptions. The question then however arises whether the bracketing of the inherent crisis character of capital, tantamount to the law of value' as the appropriation of unpaid surplus labour and its internal contradictions, renders it appropriate as a theory of capitalism. Before we come to an overall conclusion concerning Uno's project, we should briefly return to aspects of crisis in the Principles, insofar as the discussion in the present chapter has not considered them yet.

\subsubsection{Aspects in Uno's Theory of the Business Cycle (1): The Supply of Labour Power and Accumulation}

In his main work, the Principles, Uno argues for a close relation between the supply of labour power, the law of population 'peculiar to capitalism', the fall in the rate of profit, and the innovation of productive methods (the renewal of fixed capital) in terms of business cycles (keiki junkan). As mentioned earlier (Chapter 4.1.), Uno therefore provides a theory of business cycles, but lacks a theory of crisis. ${ }^{429}$ Partly, this theory is accounted for by the method of presenting a 'pure' capitalist society ( junsui no shihonshugi shakai), a society fully capable of 'self-sustaining by itself (sore jishin ni sonritsu suru) one historical society in completion' ${ }^{330}$ Accordingly, it is not the inner contradictions of the capitalist mode of production that form Uno's object of interest, but to the contrary, capital's ability to function. From this view alone, the approaches of Marx and Uno present irreconcilable opposites. More generally, as discussed throughout the present volume, for Uno, capitalist production essentially hinges on the commodification of labour power and its unobstructed supply to the production process. While the labour power commodity is the only commodity 'which capital by itself cannot directly produce', because the reproduction of that commodity falls to the 'private lives of workers', there is

429 Even though he has written a work of the same name, Theory of Crisis (Kyōkōron, 1953). In this work, however, the business cycles rather than the secular crisis of capitalism stand in focus. This is based on his work in the Principles 1950-2 and reproduced in the 1964 version.

430 Uno 1964, p. 12. 
no inherent limit to the accumulation of capital so long as capital is well supplied with labour-power ... in the form of surplus population. Hence, so long as labour-power is available, there is no theoretical reason why capital may not continue to expand its production with the given technical method. ${ }^{431}$

In the phase of prosperity, when a relative surplus population forms the pool for the new supply of labour power, the technical composition of capital usually remains the same. A relatively large quantity of workers alone, however, does not correspond to growing productivity. As seen in the discussion of the LTRPF, rising productivity entails the reduction of the total number of workers, accompanied by a rising OcC and rate of surplus value. If Uno characterises the expansion of capitalist production as being secured by the supply of labour alone, then he cannot have the development of the forces of production in mind that precisely seeks to save the cost of labour. Indeed, for Uno, rising productivity, the formation of a relative surplus population, and a rising occ are no constant conditions for capitalism's 'self-sustenance'. Capital, for Uno, 'does not constantly improve the method of production', because fixed capital must be used over a span of several - in average, ten - years, and new technical methods are not quickly applied. Hence, so long as labour power is available, production can continue on the same scale. We need to keep Uno's axiom in mind for our critique of this 'basic condition' for the expansion of capitalist production.

For Uno, the given technical production method, however, may change as the result of pressures of other capitals, so that a rise in the occ cannot be excluded. Nonetheless, the occ, according to Uno, only rises in a particular phase of cyclical fluctuations that 'characterise the development of capitalism'. It is in the phase of depression that these new productive methods are applied: 'The general adoption of new productive methods must, therefore, in principle, be forced upon capital in the phase of industrial depression.432 Here is how Uno argues for the cycle of expanded reproduction:

During the phase of prosperity, capital accumulation proceeds 'extensively' under a given organic composition, absorbing surplus population already created in the preceding phase of depression. During the depres-

431 Uno 1980, p. 88; Uno 1964, p. 169.

432 Uno 1964, p. 107. Sekine's translation is different, adding 'competition': 'The general adoption of new productive methods must, therefore, in principle, be forced upon capital by the severity of competition that it faces in the phase of industrial depression'. Uno 1980, p. 53 . 
sion phase that follows a crisis, as the disturbances caused by a crisis are gradually brought under control, new methods of production are adopted providing the basis for an increase in the organic composition of capital and for the formation of a relative surplus population to be absorbed in the succeeding phase of prosperity. ${ }^{433}$

For Uno, this presents the 'law of population peculiar to capitalism', one of the 'three great laws' of the science of political economy. This relatively smooth cycle of the expulsion and the absorption of labour power therefore also bears no necessary relation to the deterioration of the living standard of the working class as such. Throughout the Principles, and also in the corresponding texts in which Uno critically discusses Marx's theory of accumulation as a theory of immiseration or pauperisation, ${ }^{434}$ Uno rejects Marx's pessimistic view of the coexistence between accumulation on higher scales and the generation of a growing surplus population. In fact, for Uno, in stark contrast to Marx, as we shall see in a short while, not only does the law of population determine the living standard of the workers, but the living standard in turn also determines the value of labour power. To facilitate an understanding of Marx's opposed view hereafter, it is useful to first reproduce Uno's argument in detail:

The standard of living is in fact not a rigidly fixed datum, being 'historically determined' in a broad sense. In the development of capitalism, the accumulation of capital historically generates a standard of living suitable to that level of accumulation, as wages rise in the prosperity phase more than they fall in the depression phase of capital accumulation, even though the net gain may fall short of the full advance in productive powers. The economic crisis, which turns prosperity into a depression, sets, in each industrial cycle, the upper limit beyond which wages cannot rise. But in the course of capitalist development through business cycles, a rise in real wages cannot be excluded. Moreover, capital in its accumulation requires, and must be able to command, labour-power whose owners demand as a basic condition of trade some improvement in the standard of living along with the general development of capitalist society. Therefore it is not true, though often asserted, that the development of capitalism necessarily implies a deterioration of the workers' living standard.

433 Uno 198o, p. 53. Uno 1964, p. 107.

434 These are in The Theory of Crisis (Kyōkōron) (Uno 1974 (1953), pp. 147-63), and in the Methodology. Uno 1974 (1962), pp. 213-48. 
Labour-power, which cannot be directly produced by labour and hence neither by capital, is a special commodity; the demand for and the supply of it must be regulated in the course of capital accumulation according to the law of population peculiar to capitalism. The working of this law determines the living standard of wage-earners, and their living standard in turn determines the value of labour-power itself. ${ }^{435}$

Capitalist accumulation therefore, in line with a use value-oriented mechanism of reproduction whose centre forms the reproduction of labour-power 'in the private lives of workers' alone, does not infringe the possibility of a production towards the demands of the population, namely an 'improvement in the standard of living. This unrealistic and apologetic view - and one may not even need take recent surveys on distribution, national income, and wealth into account ${ }^{436}$ - is however sharply contradicted by an understanding that takes the specificities of the capitalist mode of production into consideration. The aim of the acquisition of labour power by capital is not private consumption, but the valorisation of capital, 'the production of commodities which contain more labour than [the capitalist] paid for, and therefore contain a portion of value which costs him nothing and is nevertheless realized through the sale of those commodities'. ${ }^{377}$ Labour-power can be sold only to the extent 'that it preserves and maintains the means of production as capital, reproduces its own value as capital, and provides a source of additional capital in the shape of unpaid labour'.438 Hence, we have to grasp the very function of the wage form of value in altogether different terms than Uno would have it. The function of the wage in the context of the valorisation postulate of capital does not primarily

435 Uno 198o, p. 54. Uno 1964, pp. 113-14. In similar vein, see Uno 198o, p. 67, footnote 8.

436 According to the World Bank's Changing Wealth of Nations 2018-study, 'global wealth increased 66 percent from 1995 to 2014 (from $\$ 69$ o trillion to $\$ 1,143$ trillion in constant 2014 US dollars at market prices)', but inequality grows because per capita wealth in highincome OECD countries is $5^{2}$ times higher than in low-income countries (data 1995-2014). See Lange et al. (ed.) 2018, p. 5. See also the World Inequality Report 2018 (Facundo et al. (eds.) 2018), which diagnoses a constant growth of global income inequality since 1980, if at different speeds: India's income inequality rose gradually from $32 \%$ in 1980 to $56 \%$ in 2016 (in $2016,56 \%$ of the national income was received by the top $10 \%$, compared to $32 \%$ in 1980), while inequality rose abruptly in Russia (21\% to $45 \%)$. In Europe, US-Canada, China, Sub-Saharan Africa, Brazil, and the Middle East, inequality grew steadily, while in the latter three, inequality is the greatest.

437 Marx 1976, p. 769 .

438 Marx 1976, p. 769 . 
consist in the 'guaranteed reproduction' of labour power, and the significance of wage rises does not lie in the possibility of a more comfortable life for workers. Instead, a rise in the wage level indicates a decrease in the ratio of unpaid labour. And this decrease, in turn, is limited by the drive to valorisation:

If the quantity of unpaid labour supplied by the working class and accumulated by the capitalist class increases so rapidly that its transformation into capital requires an extraordinary addition of paid labour, then wages rise, and all other circumstances remaining equal, the unpaid labour diminishes in proportion. But as soon as this diminution touches the point at which the surplus labour that nourishes capital is no longer supplied in normal quantity, a reaction sets in: a smaller part of revenue is capitalized, accumulation slows down, and the rising movement of wages comes up against an obstacle. The rise of wages is therefore confined within limits that not only leave intact the foundations of the capitalist system, but also secure its production on an increasing scale. ${ }^{439}$

In mathematical terms: the rate of accumulation is the independent, not the dependent variable. The 'living standard' in turn is the dependent variable, which can never exist in any other form than the actual wage paid to the workers. Uno's insistence that the 'living standard' can be comprehended independently of the living wage of the labourer - moreover as 'determining the value of labour power' - is a phantasm in the context of the capitalist mode of production. The same goes for accumulation: since not the supply of labour power, but accumulation is the independent variable, the law of population does at no point regulate, determine or provide the law of valorisation. To the contrary. What Uno ultimately fails to understand is that in the capitalist mode of production, capital at no point 'hinges' on 'inner barriers' in terms of use value or the consumption/reproduction of the workers. The inner barrier to capital is capital itself: its law, the maximum realisation of profit, contradicts the rules of the realisation of that law, conditioned by the cost-saving, labour minimising, and capital intensive conditions of production, 'favourable' only to the costs of investment, but detrimental to returns. This is the exact sense in which the realisation of the law of value collides with the law of value itself: as capital's self-imposed drive towards valorisation whose only source is the appropriation of alien and unpaid labour, the source which it seeks to abolish.

439 Marx 1976, p. 771. 
But Uno's views do not halt at a view of capitalist accumulation that could be reconciled with a tendency to an improvement of the living standards of wage workers. He criticises Marx's theory of surplus population and the industrial reserve army for not belonging to the theory of 'pure' capitalism. From such a theory, 'the law of pauperisation' must be excluded, because 'it is in reality no more than a circumstantial phenomenon, according to which relative surplus population is alternately formed and absorbed through the cyclical process of growth.440 We have discussed this problematic rejection in Chapter 2 of this volume. Uno, against Marx who stresses accumulation as the independent variable and the law of relative surplus population as the dependent one, however insists that 'Marx's concept of "industrial reserve army" connotes more than can be strictly treated in pure theory' and maintains: '... the limits [of the laws of demand and supply of labour] are certainly not inconsistent with an improvement in the living standards of the working class ... ${ }^{441}$ For Marx, as previously discussed, a growing redundancy of labour in the course of capitalist accumulation is the other side of the coin of a growing occ. However, this tendency for the growing redundancy of labour, in turn, becomes a lever to the greater centralisation and concentration of accumulation. Concentration and centralisation of accumulated capital hence become a 'development within the development' for which the tendency to the redundancy of labour gives the necessary incentive. In the analysis of the effect of a shift towards a higher occ for the working population, Marx therefore states:

With the growth of the total capital, its variable constituent, the labour incorporated in it, does admittedly increase, but in a constantly diminishing proportion. The intermediate pauses in which accumulation works as simple extension of production on a given technical basis are shortened. It is not merely that an accelerated accumulation of the total capital, accelerated in a constantly growing progression, is needed to absorb an additional number of workers, or even, on account of the constant metamorphosis of old capital, to keep employed those already performing their functions. This increasing accumulation and centralization also becomes in its turn a source of new changes in the composition of capital, or in other words of an accelerated diminution of capital's variable component, as compared with its constant one ... it is capitalist accu-

440 Uno 1980, p. 66. Uno 1964, p. 112. Uno here calls pauperisation a 'contingent phenomenon'. Ibid.

441 Uno 198o, p. 67. Uno 1964, p. 115. 
mulation itself that constantly produces, and produces indeed in direct relation with its own energy and extent, a relatively redundant working population. i.e. a population which is superfluous to capital's average requirements for its own valorization, and is therefore a surplus population. ${ }^{442}$

Uno laments that Marx had allegedly 'de-emphasised' the 'important contrast between the absorption of surplus population in prosperity and the formation of it in a stagnation. Marx rather one-sidedly stresses the formation of surpluspopulation, endeavouring to establish the law of population on the basis of this aspect alone.443 Indeed, the contrast between Marx and Uno cannot be more apparent than in the treatment of the effects of capitalist accumulation on the working population. In other words, the general law of capitalist accumulation in relation to a growing redundancy of labour is precisely the opposite of what Uno terms the conditio sine qua non of the expansion of capitalist production, namely the necessary supply of labour power. In the French edition of the first volume of Capital, Marx himself has directly objected to determining the supply of labour power as the necessary condition of capital's expansion:

... at the same time as the number of workers attracted to capital reaches its maximum, the products become so superabundant that the smallest obstacle to their sale can make the social mechanism appear to halt; the repulsion of labour by capital happens suddenly, on the largest scale and in the most violent manner; the disorder itself imposes on capitalists supreme efforts to economise on labour. ${ }^{444}$

442 Marx 1976, pp. $781-2$. From this relative surplus population that becomes a disposable 'lever' to the production process, the industrial reserve army is formed 'which belongs to capital just as absolutely as if the latter had bred it at its own cost. Independently of the limits of the actual increase in population, it creates a mass of human material always ready for exploitation by capital in the interests of capital's own changing valorization requirements'. Marx 1976, p. 784.

443 Uno 198o, p. 64. Uno 1964, p. 108.

444 Marx 1989 [1872-5], p. 553. Translation from the French by S. Clarke, in Clarke 1994, p. 256. Marx here also mentions the role of credit in deceiving political economists as to the causes and the 'periodicity' of cycles. Marx 1976, p. 786. On this point, Clarke observes: 'The cause of crisis appears to lie in the particular factor which triggered the crisis, which may be a shortage of labour power, or raw materials, or the limitations of the market, or a tightening of credit, but which of these emerges as the immediate barrier to accumulation is a subsidiary issue to the fundamental determinant of the tendency to crisis, which is the 
With the growing scale of accumulation, a greater attraction of labour is accompanied by a greater repulsion, and this repulsion and contraction of production happens in 'fits and starts' in proportion to the preceding expansion. Even if a sudden fit of expulsion - a rapid growth in the occ, the 'setting free' of labourers - should have a 'rejuvenating' effect on the ongoing production cycle, the effect of the next contraction will be more disastrous, in both mass and scale.

As Clarke observes, the political significance of Marx's general law of accumulation lies not in the automatism of generating a 'revolutionary class' that will overthrow what has put it in fetters. The law of accumulation - in that it induces a necessary polarisation between accumulated, concentrated and centralised capital on the one hand, and a growing mass of redundant workers on the other - lies in its generality, the fact that 'every worker is subject to the same law, since every worker is, from the point of view of capital, merely a part of the common mass of disposable labour power, facing competition from other workers, and the constant threat of expulsion into the reserve army. The general law is thus the basis of a common experience of the working class, and so the foundation on which workers can unite as a class. ${ }^{445}$ Needless to say, within Uno's self-imposed methodological confinements to a theory of 'pure capitalism', this aspect is anathematic. To be sure, Marx did not write Capital as a theory of revolution. But he did not write it because, precisely by the fetishism-critical analysis of the capitalist mode of production and its 'sycophants', the political economists, the insight into the necessity of revolution would be generated, as we can see especially in the chapters on the 'General Law of Accumulation' in Capital Volume I. Uno's theory abstains from this impetus. The question remains at what point and whether at all revolution plays a significant role for Uno: after all, capitalism manages to check its inherent crisis tendencies in every new periodic cycle. Oddly enough, Uno recognises the importance of Marx's LTRPF - but it remains 'sublated' within the framework of economic cycles. Let us see in the next and final section of this chapter how Uno perceives of the crisis tendencies of the falling rate of profit within his theory of business cycles.

tendency to the overaccumulation of capital in relation to the opportunities available to it'. Clarke 1994, p. 259.

445 Clarke 1994, p. 251. 


\subsubsection{Aspects in Uno's Theory of the Business Cycle (2): The Renewal of Fixed Capital and the Falling Rate of Profit}

Uno assumes a tight relationship between the adoption of new productive methods, the renewal of fixed capital, and the falling rate of profit within the investment cycle. To disentangle the different instances of the cycle, we shall consider the individual causes and effects that determine the cycle.

In the pursuit of relative surplus value, capital seeks to introduce 'new and technically improved' machines in order to gain a surplus profit so long as this new productive method has not yet become generalised: 'Generally speaking, capital produces relative surplus value by pursuing such a surplus profit and in the course of that pursuit improves upon the current method of production.' ${ }^{46}$ The surplus profit earned by the innovating capital is formed by the difference between the commodity's individual and its market value, so that the new production techniques allow the capital in this segment of production to sell its commodities below their market value. This development can go on for a particular span of time, depending how quickly other capitals in the same segment of production adapt the new (or even newer) methods. A new market value is determined when the market price has fallen to such an extent that no capital in this segment can any longer gain a surplus profit, i.e. when the new productive method has become generalised. A falling rate of profit is thus the direct consequence of the generalisation of a risen occ, for Uno, as for Marx. However, as noted before, for Uno, 'the development of the capitalist method of production does not constitute a continual and uninterrupted process of technical improvement because the presence of fixed capital is incompatible with such a process'. ${ }^{447}$ Since fixed capital is only introduced at a phase of depression, forced upon an individual capital through competition, it cannot be the cause for depression, expressing itself in a fallen market value, but much rather its effect. It is an effect, however, that must, towards the end of the cycle, cause a new crisis, or else Uno's implicit distinction between the adoption of new productive methods and the renewal of fixed capital becomes implausible. For Uno, the implicit distinction between the two seems of a more technical nature: because of its inertia and fixity, the presence of fixed capital does not permit capital to adopt a technical improvement at any time. For Uno therefore, thinking himself to be in line with Marx's own views of a cyclical explanation of crisis, the investment cycle begins and ends with the renewal of fixed capital. Once fixed capital is renewed, 'the opportunity for capital to start afresh in a

446 Uno 1980, p. 86. Uno 1964, p. 164.

447 Uno 1980, p. 87, Uno 1964, p. 169. 
renovated environment is given' ${ }^{448}$ The falling of wages, the overabundance of commodities, and the devaluation of capital are unable to restore prosperity: 'The general decline of prices and wages ... cannot immediately introduce the recovery phase because it does not remove the real cause of crisis and depression. ${ }^{449}$ For Uno, the role of the renewal of fixed capital becomes decisive: because fixed capital may hamper the adoption of new methods of production, once fixed capital is renewed, production can start afresh:

Only with the advent of new methods of production in the course of the so-called industrial rationalisation can a new workers-versus-capitalists relation be redefined, upon which a fresh development of productive powers is made possible. The depression is now transformed into prosperity. Thus the improvement by capital of the methods of production can only proceed intermittently in the process of business cycles, the recurrence of which is based upon the periodic renewal of fixed capital and the formation of [a] relative surplus population..$^{450}$

Here, the application of new methods of production is simultaneous with the renewal of fixed capital, so that both constitute the beginning of the cycle. If we however assume, with Uno, that the renewal of fixed capital introduces the beginning of the cycle, then we are confronted with the problem of causation, because we might as well contend that the replacement of fixed capital is itself determined by the periodicity of that cycle. One characteristic feature of crisis is the massive devaluation of capital, including its fixed form in plant and machinery. Then although, physically, these machines still function, they are 'morally depreciated': '... in addition to the material wear and tear, a machine also undergoes what we might call a moral depreciation. It loses exchange-value, either because machines of the same sort are being produced more cheaply than it was, or because better machines are entering into competition with it'.451 The scrapping of plant and machinery, and its substitution for new machines, therefore follows from the moral depreciation of capital in value terms, as a result of competition, etc. The renewal of fixed capital is therefore in itself not the lever of the new cycle, but the cycle itself - defined as it is by the valorisation postulate - determines under which conditions the renewal of fixed capital will yield an additional profit. It is important to note that Uno

\footnotetext{
448 Uno 198o, p. 89, Uno 1964, p. 171.

449 Uno 1980, p. 89.

450 Uno 1980, p. 89, Uno 1964, p. 171.

451 Marx 1976, p. $5^{28 .}$
} 
thought himself to be in line with Marx's understanding of periodic investment cycles. While, as we have shown, Marx's view of crisis is radically different - for Marx, economic cycles and the crisis tendency of capital are not the same - it must be noted however that throughout Capital, Marx does refer to periodic cycles of the expansion and the contraction of production, particularly in relation to accumulation, and the growing obstacles these cycles confront in the development of concentration. He also discusses cycles in the relation to the renewal of fixed capital. It is first discussed in the Grundrisse, especially in relating production crisis to a cycle of the average time span it takes for fixed capital to wear out:

A longer total period is therefore posited as the unit in terms of which its turnovers are measured, and their repetition is now linked to this unit not merely externally but by necessity. According to Babbage, the average reproduction of machinery in England takes 5 years; hence, the real, probably 10 years. There can be no doubt at all that the cycle through which industry has been passing in plus ou moins ten-year periods since the large-scale development of fixed capital, is linked with the total reproduction phase of capital determined in this way. We shall find other determining factors too, but this is one of them. There were good and bad times for industry and for the harvests (in agriculture) in the past, too. But the several-year-long industrial cycle divided into characteristic periods, epochs, is unique to large-scale industry. ${ }^{452}$

The ten-year-cycle therefore characterises the turnover or the 'total reproduction phase' of capital.

In general, however, the substitution of fixed capital is discussed in Capital Volume II, especially in the reproduction schemes. And yet, the problem of the renewal of fixed capital is linked to the problem of the source of the money to realise the surplus value, not in association with crisis.

Moreover, there is a problem of both historical and systematic dimensions involved in asserting the cause of crisis to lie in the periodic renewal of fixed capital. In their research, Marx and Engels had both realised that, roughly in the time span between the 1850s-70s, the character of the cycle had changed. The ten-year period no longer presented a reliable calculating magnitude for

$45^{2}$ Marx 1987 [1857-61], p. 105. Babbage was a British economist (1791-1871) whose work On the Economy of Machinery and Manufactures (1832) Marx has read in French translation. Marx references the French translation (Traité sur l'économie des machines et des manufactures) on pp. $375^{-7}$. 
determining cycles tied to the wear and tear (or the 'moral depreciation') of fixed capital, as we both learn from the letters exchanged between Marx and Engels, ${ }^{453}$ and also the supplements Marx added to the French edition of Capital. ${ }^{454}$ So while the industrial cycles of the middle of the nineteenth century had been dominated by one or two leading industrial sectors, particularly cotton and railways, and had been centred on Britain', as Clarke points out, capitalist production had expanded to many other, various branches of production so that "[the] diffusion of capitalist production had undermined any tendency to general crisis that might be based on the replacement cycle of fixed capital'.455 Especially since the renewal of fixed capital does not take place in unison, but at individual intervals depending on the founding of new enterprises, a general tendency cannot be easily constructed. A quasi-natural assumption of a ten-year periodic cycle, marking the renewal of fixed capital as the end viz. the starting point, is therefore not only highly dubious, but a 'non-solution to a non-problem,',56 since these intervals do not happen smoothly. Nor can an average of ten years be determined within the capitalist development that depends rather on 'new productive methods' introduced by an increasingly fierce competition. In other words, Uno hypostatises Marx's '10-year-period' as an explanation of cyclical crises, while he makes no mention of the general tendencies of capitalist accumulation that express themselves in increasing obstacles to the realisation of profit, which marks the contradictory character of the capitalist accumulation process itself. Although for Uno the renewal of fixed capital, because of its inertia and slow adjustment to new productive methods, forms the crucial point of tension for the periodic cycles that usually restores the productive powers on a higher level, it is the fall in the rate of profit that marks the real expression of crisis. To conclude, we shall therefore briefly turn to Uno's periodic understanding of the fall in the rate of profit. For Uno, 'the tendency of the rate of profit to fall can only be observed by comparing the so-called normal or average level of the profit-rate which appears in the prosperity phase of the business cycle with that which appears in the same phase of another cycle.457 Expanded production ('prosperity') for Uno however is accompanied by an 'inevitable rise of wages' which 'sharply depress

453 'Crisis. By no means burnt out on the Continent yet (esp. France). Incidentally, what the crises have lost in intensity, they have now gained in frequency'. Marx's letter to Engels, 4 November 1864. Marx and Engels 1987, p. 19.

454 See Marx's remark that periods of boom, in which workers received higher wages, were becoming shorter. See Marx 1989 [1872-5], p. 553 .

455 Clarke 1994, p. 267.

456 Clarke 1994, p. 261.

457 Uno 1980, p. 89 and Uno 1964, p. 175. 
profit'. Economic crises, Uno subsequently contends, arise 'fundamentally from the superabundance of capital due to this sudden fall in the rate of profit', so that the rise of wages is the primary reason for a fall in the rate of profit, similar to what Ricardo states. To be sure, for Marx, too, a high value of labour power will depress profit, and is therefore incompatible with the development of the capitalist mode of production. But then the wage level and the number of workers cannot be the real cause for crisis. Marx therefore rejects a theory of 'profit squeeze' as an explanation of the fall in the rate of profit, but locates it, as we have seen, in the drive of capital to expand the forces of production without limit. The rise and the fall of wages is the primary determinant of the pattern of accumulation, so that the supply and demand of labour does not form a coherent explanation of crisis, at least not one that is a 'theory of the dynamics of the capitalist mode of production which establishes the tendency to crisis as something inherent in those dynamics'. For Uno, however, with the determination of the periodic fluctuation of the profit rate according to the supply of labour power as the constant variable, the explanation of 'business cycles' is exhausted: 'Capitalism ... develops through business cycles of some definite periodicity; the general rate of profit, too, tends to fall as it fluctuates in the course of the cyclical process. ${ }^{458}$ For Uno, therefore, 'the social regulation of capitalist-economic processes requires two laws of profit to supplement the law of value':

the law of the equalisation of profit-rates on the one hand, and the law of the falling tendency of the profit-rate on the other. According to the former, the centres of gravity of fluctuating prices are production-prices instead of values; according to the latter, the tendency of the rate of profit to fall asserts itself only in the long run across cyclical ups and downs. 459

Uno rejects two basic results form Marx's own analysis: labour values as forming the centre of gravitation for prices of production, and not vice versa, ${ }^{460}$ and the framework of the LTRPF, which is completely independent of the theorisation of business cycles. In this chapter on the law of value as the law of crisis, we could see how capital, by creating the conditions for the production

$45^{8}$ Uno 1980, p. 89 and Uno 1964, p. 175.

459 Uno 1980, p. 9 o and Uno 1964, p. 176.

46 o Prices of production forming the 'centres of gravity' is thoroughly implausible: since they are only (a very distorted) expression or appearance of values, i.e. a value form, they cannot themselves form a 'centre of gravity'. Prices for Marx are an explanandum, not an explanans. 
of (surplus) value, simultaneously undermines the realisation of that value: this is already clear from the 'formal' possibility of crisis in money interrupting the process of 'every purchase being a sale', from the generalisation of overproduction and overaccumulation, and from the creation of a constant relative surplus population and increasing polarisation of capitalist society in the course of accumulation. We have discussed the law of the tendency of the rate of profit to fall as a consequence of increasing accumulation on a higher scale (a 'meta-theory', according to Bellofiore) as the long-term and secular tendency of capital to fail to provide the means necessary for social reproduction on the same scale by increasing the redundancy of labour. The development of capitalism is therefore inherently the development of the poverty of the mass of the population. Uno's more optimistic outlook may in part be explained by the particular historical trajectory of economic boom in 1950-6os Japan. But we have to take him by his word when he says that he wanted to present capitalism in its 'pure form', which supposedly abstracts from specific historical circumstances. In our estimation, not only is his view of business cycles mistaken, as is his insistence that the supply of labour power is the most fundamental variable. His principal misrecognition of capital as a fundamentally contradictory mode of production shows the limits to Uno's approach towards a 'pure theory' - a theory which would have to account for the contradictory character of its object.

But what is the impact of Uno's 'pure theory', the method of his three-level approach to political economy, on more recent discourses of value and money, the historical and the logical, and the prospect of revolution, both in the Japanese and the international context? Because Uno's theory was not confined to its own theoretical context and setting in late 1940s to 1970s Japan, and was adopted, reconsidered, and - as we will show - even radicalised, we shall conclude this study with a critical evaluation of its reception. 